\title{
Judicial Independence in Pakistan: A Case Study of Lawyers' Movement, 2007-2009
}

Shabbir Ahmad Khan

sakhan7@gmail.com

Follow this and additional works at: https://researchrepository.wvu.edu/etd

Part of the Political Science Commons

\section{Recommended Citation}

Khan, Shabbir Ahmad, "Judicial Independence in Pakistan: A Case Study of Lawyers' Movement, 2007-2009" (2021). Graduate Theses, Dissertations, and Problem Reports. 10333.

https://researchrepository.wvu.edu/etd/10333

This Dissertation is protected by copyright and/or related rights. It has been brought to you by the The Research Repository @ WVU with permission from the rights-holder(s). You are free to use this Dissertation in any way that is permitted by the copyright and related rights legislation that applies to your use. For other uses you must obtain permission from the rights-holder(s) directly, unless additional rights are indicated by a Creative Commons license in the record and/ or on the work itself. This Dissertation has been accepted for inclusion in WVU Graduate Theses, Dissertations, and Problem Reports collection by an authorized administrator of The Research Repository @ WVU.

For more information, please contact researchrepository@mail.wvu.edu. 
Judicial Independence in Pakistan: A Case Study of Lawyers' Movement, 2007-2009

Shabbir Ahmad Khan

A Dissertation submitted to the

Eberly College of Arts and Sciences

at West Virginia University

In Partial Fulfillment of the Requirements for the Degree of

Doctor of Philosophy

in

Political Science

John C. Kilwein, Ph.D., Chair

Jeff Worsham, Ph.D.

Shauna F. Fisher, Ph.D.

Robert D. Duval, Ph.D.

Department of Political Science

Morgantown, West Virginia

2021

Keywords: Social Movements, Cause-Lawyering, Judicialization of Politics, Lawyers' Movement, Judicial Independence, Transitioning Democracies 


\section{Abstract \\ Judicial Independence in Pakistan: A Case Study of Lawyers' Movement, 2007-2009}

\section{Shabbir Ahmad Khan}

This study focuses on a social movement, the Lawyers' Moment 2007-2009 of Pakistan, a transitioning democracy, which brought vast changes in its judicial system, especially in terms of its judicial independence. There are three main research questions in this study: 1) the status of judicial independence before the Lawyers' Movement; 2) was judicial independence a major goal in the Lawyers' Movement? and 3) did the Lawyers' Movement alter the status of judicial independence? The research methodology used to explore the answers to these questions also has three main sources: 1) the literature which explains some areas of scholarship in social movements and their impacts, including, cause-lawyering, political development, and the judicialization of politics; 2 ) opinions and observations of 30 elites directly connected with the Lawyers' Movement including lawyers, jurisprudents, retired judges of superior courts, academicians, parliamentarians, politicians, media persons, and the representatives of civil society; and 3) a survey completed by these 30 elites indicating the status of judicial independence before and after the Lawyers' Movement. The research findings in this study clearly show an overall political development in the country along with a significant change/improvement in the judicial system, in particular, the independence of judiciary after the historic Lawyers' Movement in Pakistan. 


\section{Dedication}

To the martyred cause lawyers who were burnt alive in the cities of Sahiwal and Karachi. From their charred remains a glimmer of light flashed in the form of the independence of judiciary in

Pakistan. Today we largely owe a free and independent judicial system in this country due to the indefatigable struggle and sacrifices made by these great souls. 


\section{Acknowledgement}

My greatest debt of gratitude is to my Committee Chair Dr. John Charles Kilwein. He has also been an outstanding class teacher and a mentor during the time of my course work. I took a number of his courses on judicial politics and public law which motivated and compelled me to take interest in courts and their working. I still remember the time and pain he took in guiding and supervising me even before I chose the topic of my research. He helped me at every step of this project, from preparing the prospectus to its defense, and the method and manner of incorporating all his suggestions and guidelines in the preparation for my dissertation. I feel myself a very lucky man to have benefited from the scholarship of Dr. John C. Kilwein as Committee Chair. I cannot adequately thank him for the tremendous help and guidance he provided me in the completing this project.

I also feel myself highly indebted to all my Committee Members, Dr. Jeffrey S.

Worsham, Dr. Robert D. Duval, and Dr. Shauna Fisher. Dr. Jeff Worsham has also been my professor and as Graduate Director he provided me the opportunity to teach classes. He has always been kind and supportive in choosing the required courses throughout the Ph.D. studies. Similarly, Dr. Richard Brisbin Jr. has also been my professor and the committee member in the beginning who helped me a lot to prepare my prospectus. I always treasure his guidance and invaluable comments on my prospectus. I feel myself highly honored and obliged to have Prof. Dr. Robert D. Duval and Dr. Shauna Fisher on my dissertation Committee.

Although Dr. Mathew Jacobsmeier has not been my professor, his role as the Graduate Director was very supportive and important. In particular, he was accommodative when I requested for the extension period of my dissertation, Dr. Matt Jacobsmeier guided me well and always encouraged me. I am highly grateful to him for his kind support. 
It would not be fair if I do not mention here the names of two great ladies at the Department of Political Science, WVU, Lee Ann Greathouse, Administrative Assistant, and Rony Thompson, Program Assistant. I have served in the department as a Ph.D. student and as a faculty/instructor. In my daily work, Lee Ann and Rony have always been fully cooperative.

Zafar Aziz Chaudhary is a retired civil servant, a prolific writer, an author, a columnist, and above all my father-in-law. He is an MA in English Literature and also holds LLB (Bachelor of Laws degree). I feel indebted to him for his precious time to see the first drafts of the chapters for their proofreading. My thanks are due to him also.

I could not ignore my wife Asma Zafar, my daughter Aleezae Shabbir Khan 20, and my son Ameer Hamzah Khan 18 for providing me a peaceful environment to complete my project. They also gave me moral support and cheered me in my somber moments. My task was made easier by their moral support.

I cannot finish this acknowledgement without mentioning a few of my university professors, friends and colleagues, with whom I remained in constant touch on various topics and subjects of my dissertation. The foremost was Prof. Dr. Niaz Ahmed Akhter, Vice Chancellor, University of the Punjab, Lahore, who mainly motivated and encouraged me to pursue my project in time. Similar support was given to me by Prof. Dr. Muhammad Saleem Mazhar, ProVice Chancellor of the University of the Punjab, Lahore, who gave me some invaluable suggestions regarding my project.

Some good support and help was provided to me by Prof. Dr. Khalid Mahmood, currently Dean, Faculty of Economics \& Management Sciences and the Chairman, Department of Information Management, University of the Punjab, Lahore. He helped me in providing me some good literature needed for my studies. 
Zafar Fayyaz and Muhammad Mohsin helped me in audio-taping and transcribing the interviews I held with hundreds of pages in the course of my project. Without their tremendous help and assistance, I would not have been able to accomplish my task with so much success. I also express my sincere gratitude to all of my 30 participants who gave their precious time in the session of question and answers to enable me to arrive at the right conclusions. 


\section{Brief Contents}

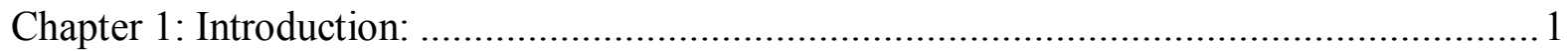

Chapter 2: Literature Review and Theory ................................................................ 7

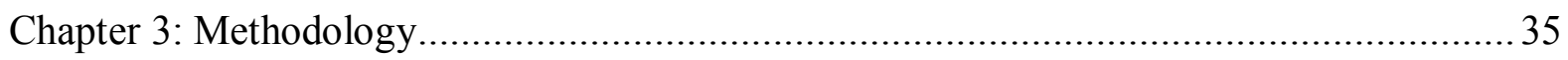

Chapter 4: The Judiciary in Pakistan: From 1947 to 2006 ............................................... 49

Chapter 5: The Lawyers' Movement: Origins and Development...................................... 88

Chapter 6: The Impact of the Lawyers' Movement ................................................... 119

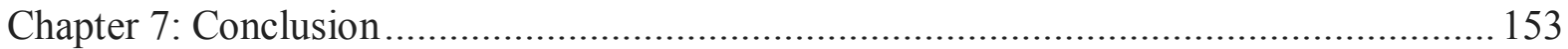




\section{Table of Contents}

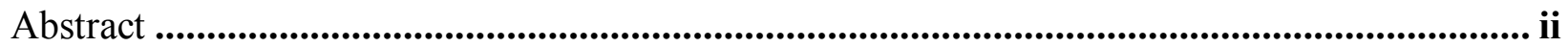

Dedication....................................................................................................................... ii

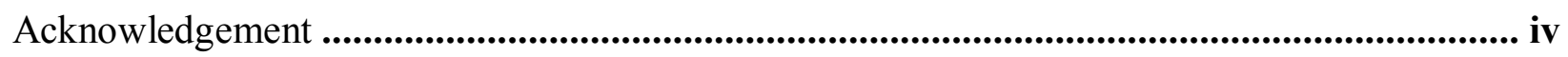

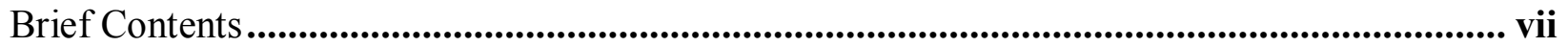

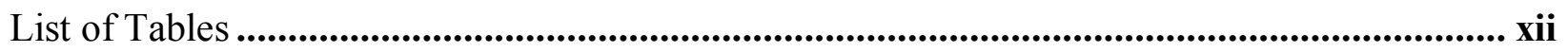

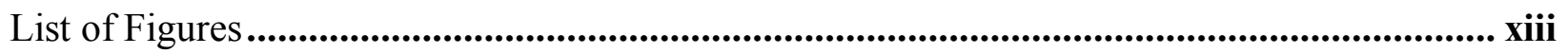

Abbreviations \& Acronyms ...........................................................................................................xiv

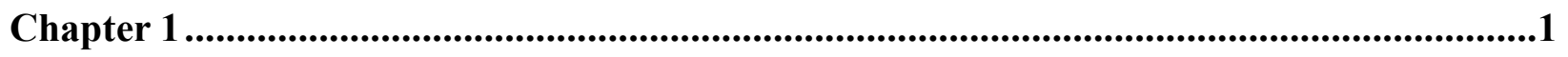

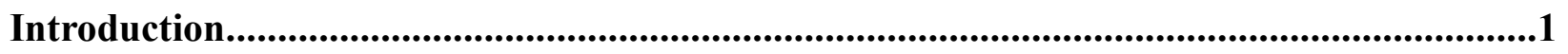

The De Jure and De Facto roles of the Courts in Pakistan ..................................................2

Objectives of the Study ..................................................................................

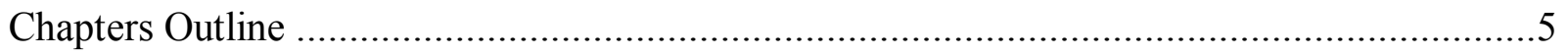

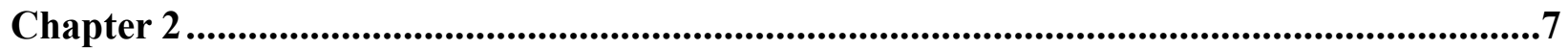

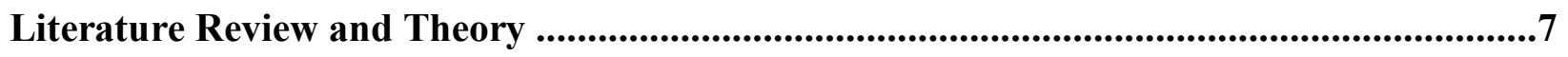

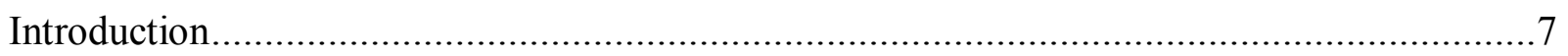

Democracy in General: Meanings and Nature.............................................................. 7

Transitioning Democracy: Meaning and Nature........................................................

The role of the Courts as Context-Bound ................................................................. 12

Courts as Upstream Triggers of Democracy .......................................................... 13

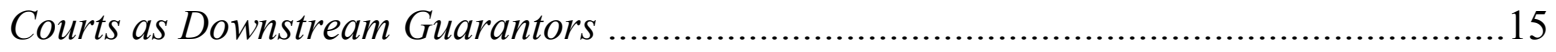

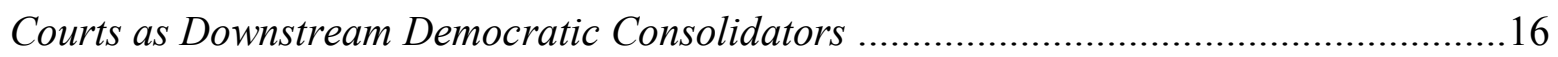

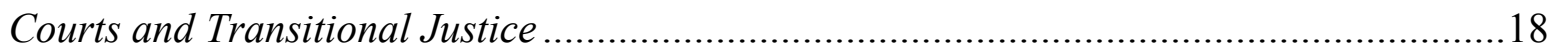

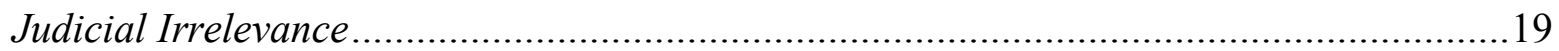

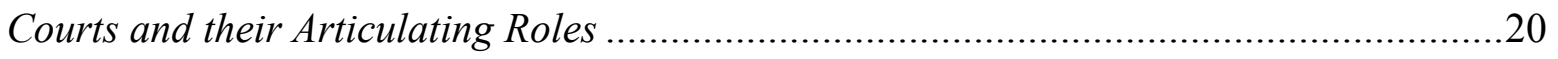

The Role of Activists: Cause Lawyering...................................................................2 21

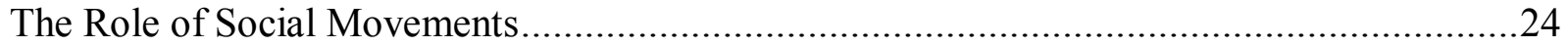

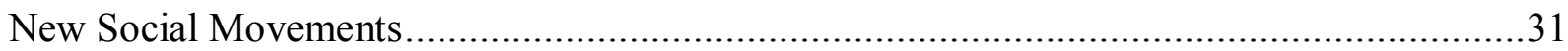

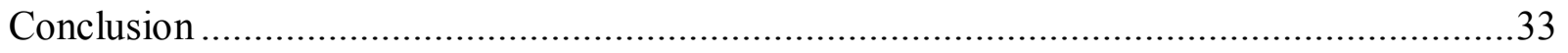




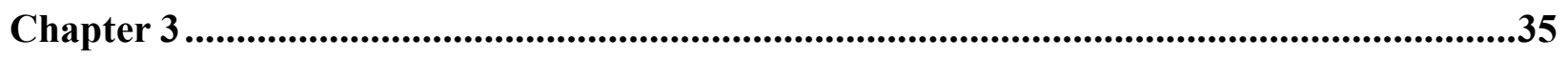

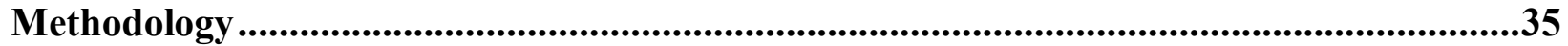

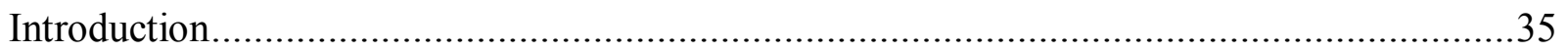

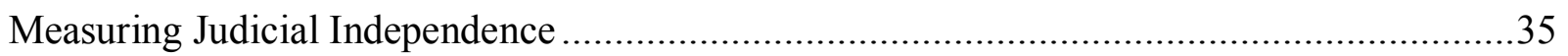

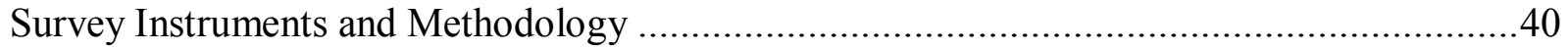

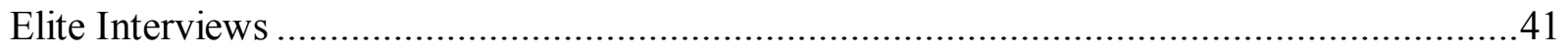

Pakistan Judicial Independence Instrument .........................................................45

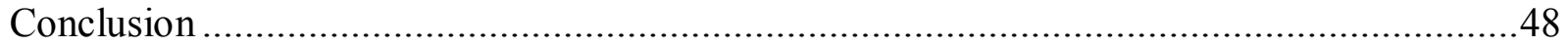

Chapter 4 .....................................................................................................................................49

The Judiciary in Pakistan: From 1947 to 2006 ........................................................49

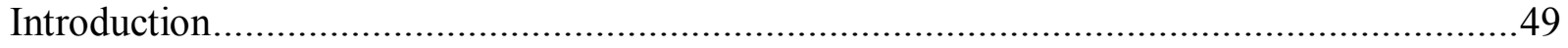

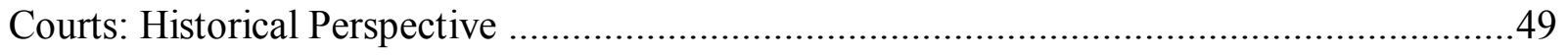

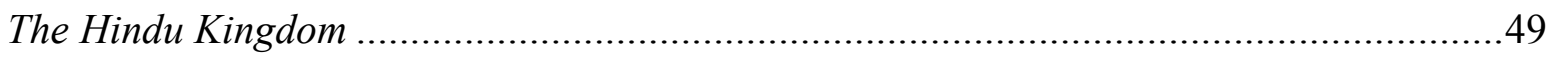

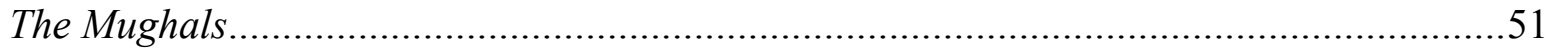

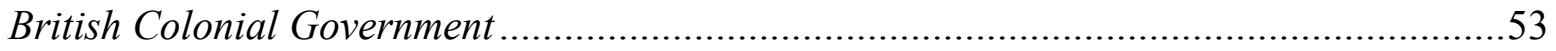

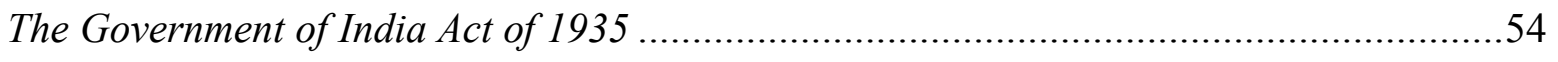

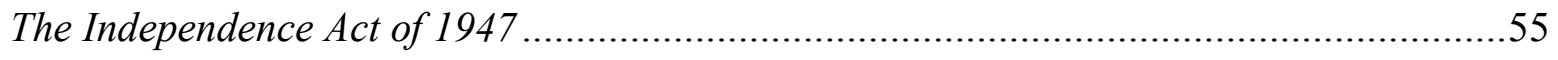

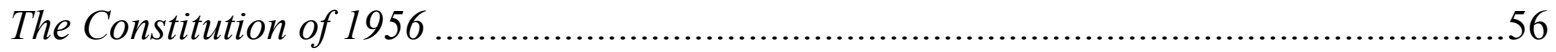

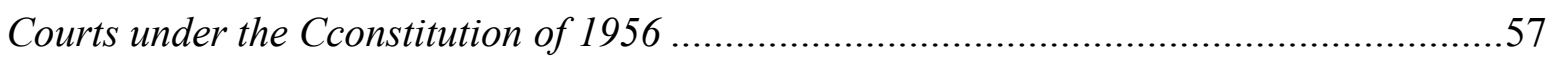

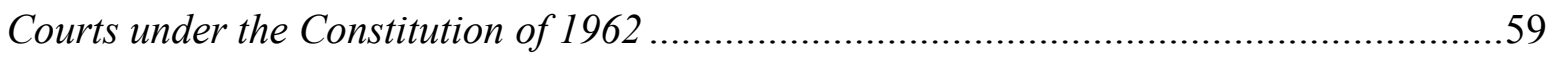

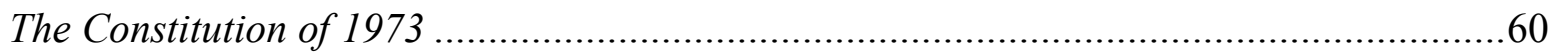

Courts under the Cconstitution of 1973 ................................................................61

Courts in Pakistan: The 'Doctrine of Necessity' ............................................................63

The De Facto Role of the Courts in Pakistan .................................................................64

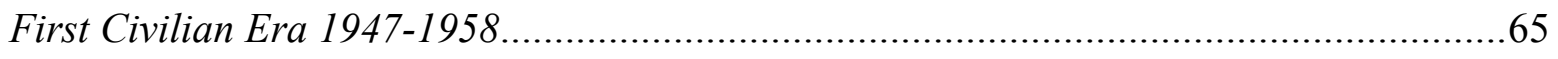

Federation of Pakistan v. Maulvi Tamizuddin Khan, PLD 1955 FC 240 .........................66

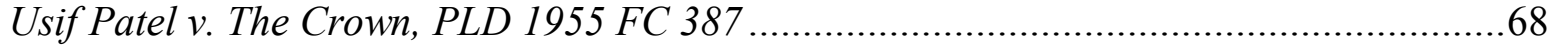

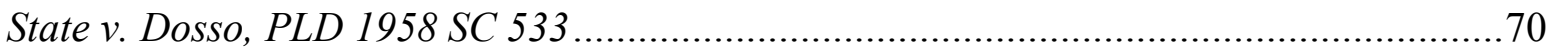

Courts under the Second Military Regime: Yahya Khan Era 1969-1971 ............................70

Asma Jilani v. Government of the Punjab, PLD 1972 SC 139 ......................................72

Courts under Second Civilian Rule: Zulfikar Ali Bhutto Era 1971-1977 ............................73 
Begum Nusrat Bhutto v. Chief of the Army Staff, PLD 1977 SC 657...............................74

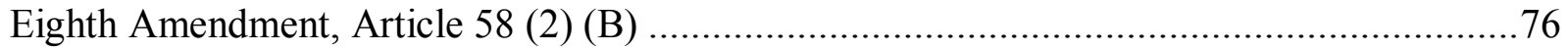

Muhammad Saifullah Khan v. Federation of Pakistan, PLD 1990 SC 79 .........................78

Benazir Bhutto and Nawaz Sharif Eras 1988-1999 .........................................................79

Ahmad Tariq Rahim v. Federation of Pakistan, PLD 1991 SC 78 ................................80

Muhammad Nawaz Sharif v. Federation of Pakistan, PLD 1993 SC 473.........................81

Benazir Bhutto v. President of Pakistan, PLD 1992 SC 59 ........................................... 82

Courts Under the Fourth Military Regime: General Pervez Musharraf Era 1999-2006 ..........83

Zafar Ali Shah v. General Pervez Musharraf, PLD 2000 SC 869 ..................................83

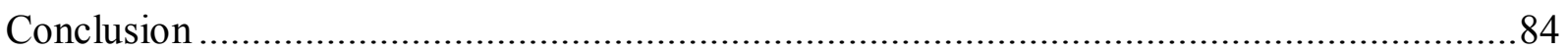

Chapter 5 ........................................................................................................................888

The Lawyers' Movement: Origins and Development ...............................................................88

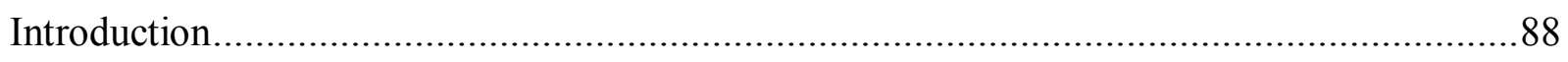

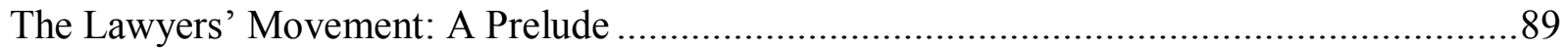

The Road to the Lawyers' Movement ............................................................................91

November 3 Emergency Plus/Mini Martial Law ..........................................................96

The Underlying Causes behind the Lawyers' Movement .............................................98

Resistance by the Chief Justice and the other Justices...............................................99

Resentment against the Military Regime ............................................................. 100

The Role of Political Parties .................................................................................. 101

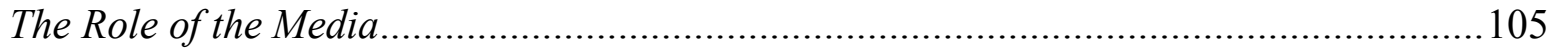

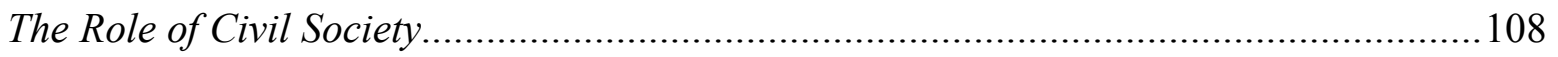

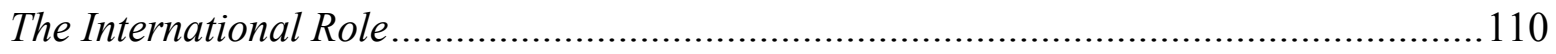

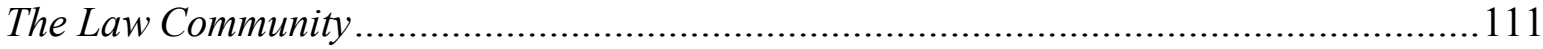

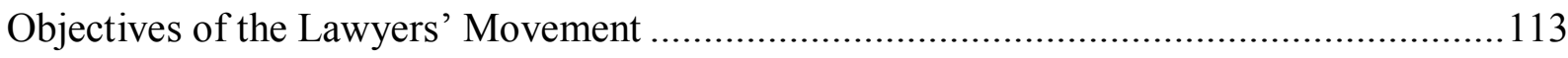

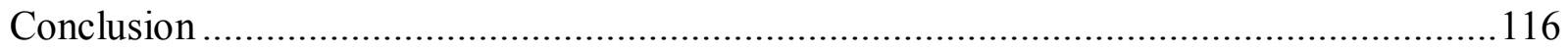

Chapter 6 ........................................................................................................................... 119

The Impact of the Lawyers' Movement ................................................................................119

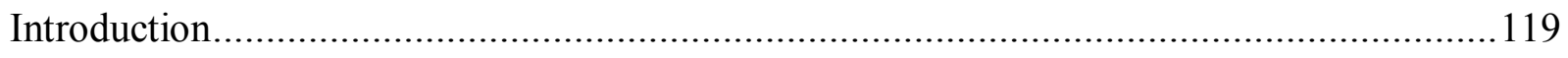

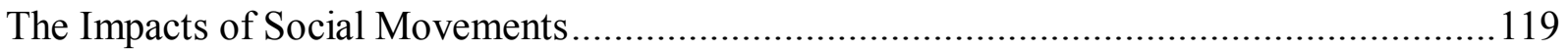

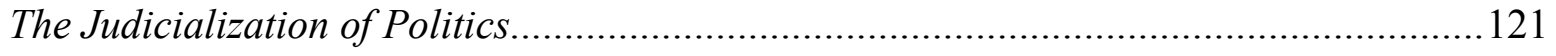


Major changes in Judicial Policy.

Judicial Independence before and after the LM: Analysis of the Survey ..............................129

Status of the Judicial Independence after the Movement: Opinions of the Respondents .......130

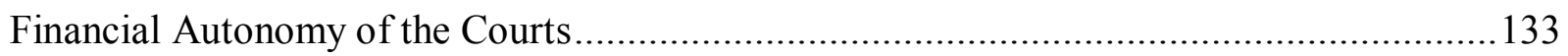

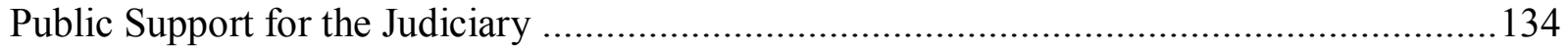

Changes in the Appointment and Removal Method of the Judges ......................................135

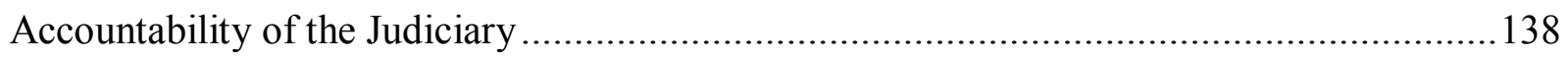

Relationship of the Judiciary with the other Branches of the Government ............................ 140

Impact of the Movement on Pakistani Society at large ......................................................... 143

Impact of the Movement on the Democratic Health of the Country ..................................... 145

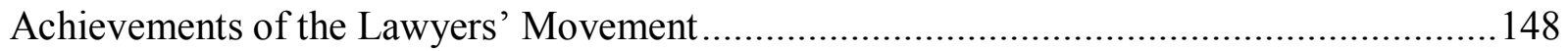

The Adverse Impacts of the Lawyers' Movement ............................................................... 149

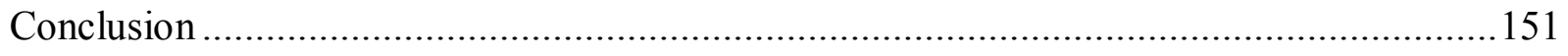

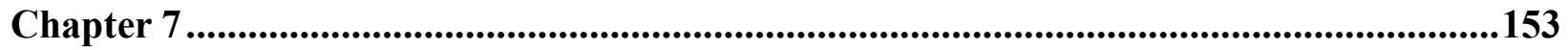

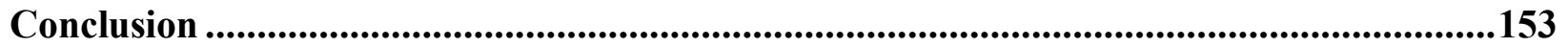

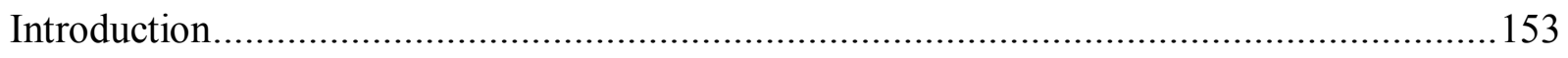

The Role of the Courts in a Transitioning Democracy ........................................................153

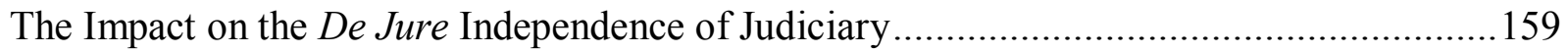

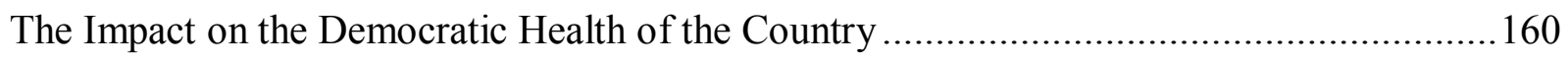

Suggestions for Future Research................................................................................. 161

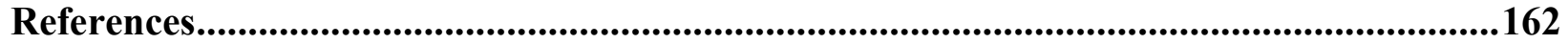

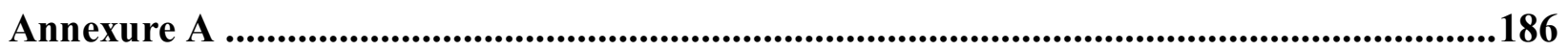

Annexure B .............................................................................................................................187 


\section{List of Tables}

Table

Title

P.

Table 3.1 The Indicators of Judicial Independence............................. 47

Table 6.1 Indicators/Determinants of Judicial Independence in Pakistan Since 1947... 131 


\section{List of Figures}

Figure

Title

Figure 3.1 Judicial Structure of Pakistan's Judiciary

Figure 5.1 Mistreatment of Police with the Deposed Chief Justice..............
62

P.

107 


\section{Abbreviations \& Acronyms}

\begin{tabular}{ll} 
ANC & African National Congress \\
CJ & Chief Justice \\
CMLA & Chief Martial Law Administrator \\
CSR & Civil Society Representative \\
HCT & High Court \\
HP & History Professor \\
JI & Judicial Independence \\
LM & Lawyers' Movement \\
LP & Law Professor \\
MRD & Movement for the Restoration of Democracy \\
MQM & Muttahida Qaumi Movement \\
NJPMC & National Judicial Policy Making Committee \\
NLGF & National Lawyers Guild Foundation \\
NSM & New Social Movements \\
PCO & Provisional Constitutional Order \\
PIL & Public Interest Litigation \\
PLD & Pakistan Legal Decisions \\
PJC & Pakistan Justice Coalition \\
PML (N) & Pakistan Muslim League (Nawaz) \\
PNA & Pakistan National Alliance \\
PS & Political Science \\
SCT & Supreme Court \\
SJ & Senior Journalist \\
SL & Senior Lawyer \\
SM & Social Movements \\
\hline
\end{tabular}




\section{Chapter 1}

\section{Introduction}

Scholars and researchers in political science, particularly, in the area of judicial politics view judicial independence as a critical component of modern liberal democracies. Judicial independence is a complex phenomenon, difficult to define and measure, although most observers agree that the distinction between de jure and de facto is essential. All agree the nature of judicial independence is shaped by the type of system in which the courts operate: authoritarian, democratic, or emerging/transitional democracies. My dissertation focuses on Pakistan, a transitioning democracy, and seeks to illuminate three important features regarding the development and evolution of judicial politics in Pakistan. First, in examining the development of the judicial system in Pakistan, I pay special attention to the status of judicial independence between 1947 and 2007. Second, I document the role of the Lawyers' Movement, a social movement that sought to transform the judicial system in Pakistan between 2007 and 2009, as well as to bring broader fundamental changes to the government. Finally, I examine how, if at all, the Lawyers' Movement altered the judiciary of Pakistan, again, paying attention to the status of the courts' independence. This study is grounded in the literature on social movements, mass protests, cause-lawyering, political development, judicialization of politics, and judicial independence (JI). At the core of this study are data collected from thirty in-depth interviews with Pakistani elites connected with the Lawyers' Movement, including lawyers, jurisprudents, retired superior court judges, academicians, parliamentarians, politicians, journalists, and representatives of civil society organizations. 


\section{The De Jure and De Facto roles of the Courts in Pakistan}

Historically, the role of the courts in Pakistan has been complex and controversial. As far as independence is concerned, the courts have played a shifting role under both military and civilian regimes. Scholars who study judicial independence distinguish between the de jure and de facto independence of courts, and this has been a concern in Pakistan as well. Since the inception of the country in 1947, lawmakers sought to ensure the de jure autonomy of the judiciary through constitutional and statutory arrangements. Pakistan inherited a common law tradition from its colonial rulers. Strict rules were created for the appointment of impartial judges and for their removal. The British Parliament passed extensive legislation for United India to ensure the independence of its judiciary. The Independence Act of 1947 guaranteed an independent judiciary to safeguard the rights of the citizens. Like other Anglo colonies, the Privy Council was established as the highest court of appeal of decisions of the courts in Pakistan, including the High Courts and the Federal Court.

From the framing and adoption of its first Constitution in 1956 until the implementation of its third and final Constitution in 1973, a free judiciary has been a significant feature or trait of every Constitution of Pakistan. The Courts were given a wide range of powers of interpretation of the Constitutions and laws to resolve issues among the governments of all levels and the community at large (Choudhary, 1959, pp. 240-245).

The history of the de jure role of courts in Pakistan can be divided into two major eras, first, the period when there were civilian governments in power, and second, when there were military rulers who came into power after imposing martial law and abrogating the written Constitution of the country. In addition, there were two major challenges faced by the courts. First, there were cases in which the courts had to decide the validity or legitimate right of the military rulers to rule the country under the umbrella of the notorious "Doctrine of Necessity," 
i.e., providing legitimacy to the military rulers through the court decisions. Secondly, the courts had to decide cases dealing with the dismissal of civilian governments by military presidents of Pakistan who acted under the provisions of section 58 (2) (b) of the Eight Amendment in the Constitution introduced by a military ruler as a safety valve and to put pressure on the civilian governments. According to the Eighth Amendment, the President of Pakistan could dismiss the elected government along with the federal and provincial elected legislatures. In most of these cases, the courts had to make compromises with the military leaders to insure their continued functioning, albeit with a loss of some of their independence.

Zafar (2019) argued that the Pakistani judiciary played a critical role in the polity through its de facto role in which it:1) established 'legal order' that ensured political democratic stability in the country; 2) gave relief to the citizens of Pakistan in spite of the dictatorial rule of the military junta; 3) facilitated the political forces that brought about the transition from an authoritarian regime to democratic civilian rule; 4) decided cases between the head of the state and local governments, and 5) dealt successfully with the failed attempts to topple democratic governments and tried to correct the social evils in society.

Researchers who stress the de facto role of the courts often look at how other actors or institutions shape the independence of the courts in Pakistan. Most focus on the impact of military regimes, and how PCOs (Provisional Constitutional Order) limit judicial independence (Hussain, 1992; Khan, 2016; Maluka; 1995; Newberg, 1995; Samdani, 2002; Shah, 2012). Paula Newberg (1995) concludes that Pakistani Courts assumed a responsibility to maintain social order by validating military takeovers. Her take is that the judiciary, through its decision-making, provided instructions to help the country avoid serious bloodshed and eventually come out of political and legal crises produced by military takeovers. 


\section{Objectives of the Study}

Political scientists and researchers have produced a voluminous literature in the field of social movements or protests, cause-lawyering, political development, judicialization of politics, or the expansion of the powers of the judiciary. For the most part, political scientists who examine these ideas have focused on developed political systems. There is significantly less scholarship on the application or implications of these theories and concepts on transitioning democracies like Pakistan.

Pakistan is an emerging democracy, transitioning from an authoritarian military regime to civilian rule. Pakistan is also unique because the military have consistently intervened in national politics. Research on JI in a transitional democracy like Pakistan will make a significant contribution to this important subject, especially in light of the Lawyers' Movement, 2007-2009. This movement represents a unique occurrence in the constitutional history of Pakistan where lawyers defied and helped to topple the military regime and to uphold the independence of judiciary.

The main objective of this research is to study judicial independence in Pakistan and a social movement's impact on that independence. First, the study will assess the development of judicial independence in Pakistan through 2007. Second, the study will examine the Lawyers' Movement and its objectives, especially with regard to judicial independence. Third, the study will assess the whether the Lawyers' Movement altered the status of judicial independence in Pakistan and the power of the judiciary. Through the use of an original qualitative dataset of interviews with thirty legal elites in Pakistan, this study also sheds light on the role of professionals in bringing about legal and political change in an emerging democracy. 


\section{Chapters Outline}

This dissertation consists of seven chapters. This chapter briefly addresses the de jure and de facto roles of the courts along with the main objectives of the study. This chapter also includes the chapter's outline of the dissertation.

Chapter 2 addresses the theoretical aspects of the problem, with a discussion of transitioning democracies and the concept of judicial independence, discussing the literature on de jure and de facto independence, and different methods to measure these with reference to Pakistan. I review the relevant literature on the concepts of democracy, transitioning democracies, judicial independence, and the roles of the judiciary in the developed countries, in authoritarian regimes, and in the transitioning democracies like Pakistan.

Chapter 3 highlights the major research questions in this study along with the qualitative research methods to answer these questions such as elite interviews and survey instruments.

Chapter 4 focuses on the development of the judiciary in Pakistan, dividing it into three phases: 1) the ancient period; 2) the British period; and 3) independence. This discussion also examines the de jure and de facto independence of courts in Pakistan during the various phases of development. Chapter 4 makes clear that since independence, both the political and judicial systems in Pakistan have been in transition. Pakistan has experienced four direct military dictatorships and the judiciary has had to deal with the severe consequences of the military's intervention in politics. Likewise, to survive these authoritarian periods, the courts have had to make compromises regarding judicial independence. Chapter 4 concludes with the answer to my first research question, i.e., what was the nature of judicial independence in Pakistan prior to the advent of the Lawyers' Movement.

Chapter 5 begins with the story of the LM, its beginning, underlying causes, its progenitors, its supporters, opponents, its processes, and most importantly its objectives and 
goals. Chapter 4 answers the second research question in this dissertation, i.e., was judicial independence an important goal of the Lawyers' Movement? This chapter also describes the role of the cause lawyers, judges, bar councils, civil society groups, non-governmental organizations (NGO), and political parties in this historic struggle for the restoration of the judiciary, its independence, and the rule of law in the country. Finally, this chapter throws light on the difficulties, hardships, and brutalities imposed by government agencies and opponents the activists involved in the Lawyers' Movement.

Chapter 6 uses survey and interviews data from 30 elites to assess the impact of the Lawyers' Movement on judicial politics in Pakistan. Chapter 6 is informed by three major connected areas of research: 1) social movements or protests; 2) cause-lawyering; and 3) political development.

Chapter 7 closes with a summary and conclusion regarding the Lawyers Movement, judicial independence and the future of judicial politics in Pakistan. This chapter also offers suggestions for further research on the socio-political impact of the Lawyers' Movement. 


\section{Chapter 2}

\section{Literature Review and Theory}

\section{Introduction}

My study is based on literatures in the fields of judicial independence, cause lawyering, judicialization of politics, transitioning democracies, social movements and mass protests. This chapter focuses on theories and concepts closely related to my dissertation such as social movements or mass protests and different roles of the courts (Ginsburg, 2012) in transitioning democracies like Pakistan.

\section{Democracy in General: Meanings and Nature}

The meaning of the word 'democracy' can be traced from the ancient Greek mythology in which two words: 'demo' in Greek 'dêmos' meaning 'people' and 'cracy' in Greek 'krátos' meaning 'power' refer to a system of government where power lies in the hands of the people. There are numerous definitions of the concept of democracy in literature, including Abraham Lincoln summation of democracy as a "government of the people, by the people, for the people" (Lincoln, November 19, 1863).

More recently, Schumpeter considers democracy “...that institutional arrangement for arriving at political decisions in which individuals acquire the power to decide by means of a competitive struggle for the people's vote." While Robert Dahl (1971) states that the key aspect of democracy, “... is the continuing responsiveness of the government to the preferences of its citizens, considered as political equals." Huntington defines democracy as a political set up in which "its most powerful collective decision makers are selected through fair, honest and periodic elections in which candidates freely compete for votes, and in which virtually all the adult population is eligible to vote" (Huntington, 1993, p. 7). 
Most modern observers agree with Dahl (1971), who identifies seven key features of a democratic system: 1) elected officials have control over governmental decisions; 2) officials are elected through frequent, fair, and free elections; 3) officials are elected by using the universal adult franchise method; 4) people have a right to run for the public office; 5) people are given freedom of expression; 6) people have an access to information without hindrance; and 7) people have a right to join any party or group they like.

However, the above-mentioned definitions of democracy are 'minimalist' definitions; they do not capture the issues or challenges faced by the new or transitioning democracies of the world, where the democratic systems are yet to be consolidated. Similarly, some scholars not only explain the concept, but rather focus on its various shades or patterns (Lijphart, 1984; Powell, 2000; Kaiser, 1997). They characterize democracies in terms of concentration of power or sharing power arrangements, including the different roles of the participants in the process such as institutions, parties, and groups. In this study, I consider 'democracy' in the same manner as these scholars, with an emphasis on John Locke's notion that in a democracy 'the whole power of the community' is in the hands of the 'elected representatives' of the people (Khan, 2012).

\section{Transitioning Democracy: Meaning and Nature}

Political scientists refer to 'transition theory' as capturing a transformation process from authoritarian regimes to transitioning democracies. The communist states in Eastern Europe, the former Soviet Union, the transitioning military dictatorships of Latin American, many African nations and a few Middle Eastern countries have experienced 'democratic transitions' in recent decades (Guo, 1999, p. 133). Theoretical models such as political culture, systems theory, modernization, decision theory, structural functionalist theories, and intuitionalist theory have 
had a major influence on democratic transition theory. These different theories provided an analytical framework to understand the transition phenomenon across regimes under different conditions.

O'Donnell and Schmitter (1986) offer a useful definition of the concept of transition:

The 'transition' is the interval between one political regime and another. On one side, transitions are delimited by the launching of the process of dissolution of an authoritarian regime, and on the other, by the installation of some form of democracy, the return to some form of authoritarian rule, or the emergence of a revolutionary alternative. (p. 6) Mainwaring (1989) considers this definition partially true - particularly at the beginning of a transition but not applicable to whole transitioning process in a country. Bratton and Walle (1997) define democratic transition in terms of both political liberalization and democratization such as ".... a transition to democracy can be said to have occurred only when a regime has been installed on the basis of a competitive elections, freely and fairly conducted within a matrix of civil liberties, with results accepted by all participants" (p. 194).

Guo (1999) attempted to categorize the major literature on democratic transitions into four conceptual approaches: structure-oriented, process-oriented, institutional-oriented, and political economy. The pioneers of the structuralist approach, e.g., Lipset (1959), Almond (1963), and Moor (1966), mostly worked on Latin America and Southern Europe in the 1960s and 1970s. They gave much importance to political, social, cultural and economic conditions in order to better explain democratic transitions and their outcomes. Their empirical analyses of transitioning democracies found a positive correlation between socio-economic development and democratic values. The authors not only focused on the socio-political prerequisites of democracy but its levels and stability. In contrast, the strategic choice approaches concentrated on the role of political elites and their strategic choices. Schmitter (1991), O’Donnell (1979), and Palma (1991) focused on the transition process rather than on the structural conditions. They emphasized the importance of the interaction of political elites in terms of their strategic choices, 
including their ability to compromise on contentious issues such as the transitioning and consolidation of democratic regimes.

The institutionalists emphasized the importance of the role of political institutions in shaping and constraining the goals and performances of the political actors. They also focused on the changing relationship between societal factors and state factors in the process of democratic transition. Some institutionalists tried to bridge the gap among the structural, strategic choice, and institutional approaches. They argued that preexisting political structures were the "confined contexts' that decided the rules of the game of political action. Karl (1990) and Schmitter (1991) argued that the strategic choices available to political elites were dependent upon preexisting political conditions. O'Neil applied institutional theory on the democratic transition in Hungary and found a strong relationship between the institutional forms in that country and its collapse. Other scholars used political economy approaches that emphasized the interplay between politics and the economy in order to explain the transition from an authoritarian regime to democracy. They argued that the economic conditions of a regime set the terms and conditions, along with the timing and nature of transformation of an authoritarian regime into a democratic transition. They also believed that democratic consolidation is contingent on the economic legacies of the past regime. In other words, failing to overcome economic crises could lead to a transition and succeeding in controlling economic issues consolidates democratic regimes (Guo, 1999, P. 139).

In the previous three decades, seven different regions of the world went through this transitional phase, including the fall of rightwing dictatorial regimes in Southern Europe in the mid-1970s, transformation from military rule to civilian democracies in Latin American countries during 1970s and 1980s, the collapse of communist governments in Eastern Europe in the late 1980s, the establishment of 15 independent states after the demise of Soviet Union in the 
early 1990s, the end of the one-party regimes in many nations of the Sub-Saharan Africa in the mid-1990s, and the beginning of quasi-liberal regimes in some parts of the Middle East in the 1990s. In the recent past, there were nearly 100 countries that were considered transitional democracies by political science scholars, however, only a few of them, about 20 countries in Central Asia, the Baltic region, South America, and East Asia, have made significant progress towards stable democracy (Carothers, 2002, pp. 5-9).

There are five core assumptions underlying transitioning democracy in the literature. The first and foremost is: when any country transforms, it does so from a dictatorial regime to a democratic one. The second assumption is that when cracks appear in the dictatorial order, they are due to a political liberalization. The third assumption is related to the public's belief in democratic processes such as elections. The fourth is a commitment of some political elite to change their political system. And fifth is the redesign of the political institutions such as electoral, parliamentary, and judicial reforms in which the process of state-building and democracy-building goes hand in hand, supporting each other (Carothers, 2002, pp. 6-9).

Carothers rejects the transitional paradigm because the majority of the transitioning democracies failed to become well-functioning democracies. Rather, they entered into a 'political gray zone' phase, meaning that regardless of any positive features such as genuine elections, political freedom, and regular transfer of power to different political groupings, democracy 'remains shallow and troubled' due to: 1) feckless pluralism, and 2) dominant-power politics. Despite having some of the attributes of a democracy, such as regular elections, limited political space for the opposition, independent civil society, and democratic constitutions, they lack fundamental elements of a democratic life - true representation of the people beyond 
elections, abuse or misuse of law by the government, illegitimate electoral process, lack of trust over public institutions, and weak performance of the state (Carothers, 2002, pp. 6-14).

\section{The role of the Courts as Context-Bound}

The courts, in general, and specifically in strong democracies, check the excesses of both the executive and legislative branches of a government in order to maintain constitutional order. They also lay down the foundations of sustainable economic development along with the popular support for the democratic regime (Prillaman, 2000, p.1). On the other hand, some scholars disagree that courts have an important role in democratic development, because that development is associated with social, economic, and political factors beyond the control of courts (Stotzky, p. 201). In a democratic state, the main functions of a judiciary are: 1) protecting constitutional and legal principles; 2) maintaining checks and balances among the governmental organs; 3) resolving disputes; and 4) protecting basic rights of the people (Domingo, 2000, p. 708).

Moustafa (2007), and Moustafa and Ginsburg (2008) identify five roles of courts in authoritarian regimes: 1) maintaining social control by keeping political opponents under pressure; 2) supporting the regimes' claims of legitimacy; 3) ensuring harmony among the components of the state machinery; 4) facilitating trade and investment; and 5) serving as a "non-political" forum in which regime policy is "legitimized" (pp. 5-10).

The role of courts in transitioning democracies is significantly different than courts in both developed democracies and the authoritarian regimes. The role of courts is contingent upon several contextual, situational, and strategic factors. In an unstable environment like Pakistan, the courts assume the governmental functions of the other weak institutions, including the legislature and the executive (Shapiro, 1964). In the literature on transitioning democracies, there are five 
major categories of the roles of courts, played in two major phases: 1) upstream roles in the first phase and 2) downstream roles in the second phase. As far as the upstream roles of the courts are concerned, these are the activities of courts either in the last days of an authoritarian regime, or in the early phase of a democratic transition. On the other hand, downstream roles of the courts are related to the performance of courts in the period just before the consolidation of democracy. There are two more scenarios of each phase. In the first phase, courts either become the instruments of repression in the hands of the declining authoritarian regime or act as triggers of democratization. Similarly, in the second phase, courts may play the role of 'guarantors' of either the authoritarian positions or the consolidators of democracy, in which they facilitate, one way or the other, the democratic health of the country. There might be another possibility of 'judicial irrelevance' in which courts play no discernible role (Ginsburg, 2012).

\section{Courts as Upstream Triggers of Democracy}

In some situations, particularly at the time when an outgoing authoritarian regime comes face-to-face with a strong democratic opposition, the courts have two options - either to oppress the democratic forces or to facilitate them in transition to democracy. This situation is very precarious because no one knows the outcome of the struggle beforehand. Courts are also in transition and can go along with both sides (Weingast, 1997). In those circumstances when an authoritarian regime still controls larger groups in the society, through both incentives and coercion, it becomes difficult to coordinate among democratic forces on a 'focal point.' If the courts decide to facilitate the democratization process through their decisions against the ruling elite, it might provide the opposition a common tool or 'focal' point to coordinate and provide the opposition the 'trigger' to bring down the declining regime (Schelling, 1960). But the most important question is why do people focus on the courts' decisions? Or how can courts' 
decisions create a 'common identity' for the people having multiple identities to form a coalition against the oppressive regime? Along with some other advantages, such as the acknowledgement by the court regarding the rule violations by the regime, or publicity against the government, the most significant impact could be the mobilization of the masses on the issue. Court decisions could unite the opposition against the dictatorial regime. There are also potential repercussions attached to this type of move by the courts. According to Ginsburg, if courts lack institutional and political links to power, they rarely produce decisions counter to regime interests. One example of how courts can facilitate the goals of democratic forces occurred during Ukraine's 'Orange Revolution,' when the Ukraine Supreme Court ordered a revote for the presidential elections, helping opposition candidate Viktor Yanukovych win the second election. This decision made the opposition stronger and helped it bring down the authoritarian regime.

On the other hand, there also lies a risk for judges, and courts as a whole, if their decisions to facilitate the opposition fails to attract public support, as happened in Egypt under Mubarak when the Egyptian Supreme Constitutional Court gave support to the demands of the opposition. In response, the regime restructured the court by appointing judges supportive of regime's policies. There are always chances of both possibilities, i.e., the court's crucial decisions could turn into focal points for mobilizing mass support for regime opposition, or the court's decisions may also trigger a backlash. The occurrence of the first possibility is rare in the history of democratic transitions. Nevertheless, it is argued that the Pakistan Supreme Court's decisions in the last two years of General Musharraf's regime in Pakistan, such as the Steel Mill Case and the Eligibility Case, provided focal points to the democratic forces in the country to mobilize the masses against him, particularly the people in legal profession as lawyers. 


\section{Courts as Downstream Guarantors}

The argument regarding the 'downstream guarantors' role of the courts is more or less similar to that of the supporters of democracy vs. justice analysis presented by Mihai (2010). The supporters of democracy vs. justice argument focus on a kind of compromise with the remnants of old dictatorial regime in order to consolidate democracy. An autocratic regime requires a guarantee of their policy, property, and liberty for their associates before making a final deal with the opposition to transfer power. In this situation, the courts play an important role ensuring outgoing autocrats constitutional and legal protection for regime's policies, dubbed by Hirschl (2004) as 'hegemonic preservations.' This role of courts becomes possible only in those situations where a dictatorial regime negotiates or bargains the terms of transition with the democratic opposition such as in Chile under Pinochet in the late 1980s and in Turkey under General Kenan Evren in 1982.

The constitutional and legal developments giving authority to the courts as guarantors of political and economic rights of the ruling/white minority in the last days of apartheid era in South Africa is a prime example of courts acting as the downstream guarantors (Meierhenrich, 2008). When the white ruling minority saw that they could not continue to remain in power, they empowered the judiciary to safeguard their rights after the demise of their regime. The Constitutional Court in South Africa supervised the transition process, i.e., transferring power from the old regime to a new Black majority under the leadership of Nelson Mandela and the African National Congress (ANC). The Court worked to ensure the protection of the supporters of the displaced regime, including changes in the interim constitution, incorporating global human rights provisions in the law, and most importantly, limiting the room for transitional 
justice. For the consolidation of democracy in the country, both declining and rising political forces agreed to give such a role to the courts (Klug, 2000; Lollini, 2010).

\section{Courts as Downstream Democratic Consolidators}

In some situations, courts become allies of the new democratic forces, particularly when the transition to democracy occurs after movements take power. The courts facilitate the transitional justice process, dismantling the old legal structures, empowering the legal actors, and serving the new democratic regime. After World War II, in transition from fascist rule to democracy, the Italian courts assumed this role, eliminating old fascist statutes from the books and establishing their own independent power (Ginsburg, 2012). The courts as 'consolidators' provide an open environment in which various political forces to compete. They also ensure the political players a level playing field or equilibrium through transparency and accountability across the board (Gloppen et al., 2010).

In the early phase of transition to democracy, new democratic governments prefer new courts to those of the old regime. This is because the old courts, due to their political inclination towards the previous regime, may be unable to fulfill the democratic agenda of the new government. The courts in a democratic transition become the central institution to resolve political and legal conflicts, including election-related cases, public interest litigation such as corruption, rights adjudication, inter-branch conflicts, and economic regulations. In some situations, human rights cases are also on the courts' agenda.

There are multiple examples from history where these types of issues were taken by the courts, such as the political issues handled by Thailand's Constitutional Court of 1997-2006, jurisdiction over cases by the Philippine courts, corruption and administrative adjudication by courts in Indonesia, royal immunity cases in Malaysia, individual rights decisions handed down 
by courts in Colombia, and inter-branch conflicts adjudicated by courts in Mexico and Brazil. The courts in Costa Rica focused on both rights adjudication and inter-branch conflicts. Researchers have also shown that courts can use periods of divided government to expand their power, as happened in Argentina and Chile (see Chavez 2004; Ferejohn, 1999; and Scribner, 2004).

The literature on Latin American courts also shows that ideas and local cultures are of a supreme importance in determining the role of the courts. The correlation between formal institutions and actual powers of the courts is weak. Significant institutional reforms do not guarantee substantive independence of the courts. Another observation that is important about the Latin American judiciary is that the region has gone through democratic transitions, and the courts have established norms to resist backsliding (Figueroa, 2006).

Helmke and Figueroa emphasize another important role of courts in new democratic environments, when courts decide political cases involving interpretation of the constitutional powers of governmental institutions. The powers given to various institutions are generally unclear or incomplete, requiring a third party to adjudicate in cases of inter-branch conflicts. The courts play this role as a proverbial third party in order to resolve the issue (Helmke and Figueroa, 2011). They play another important role, particularly in the Latin American countries, delivering justice in socio-economic rights litigation to the public. In such situations where there was no security for the vulnerable classes in the society, for example, the middle-class after economic crises, the courts assumed the role of a protector (Gauri and Brinks 2008). Both Smulovitz (1998) and Epp (1998) focus on the significance of institutional reforms and the strengthening of support structures for the judiciary to face the challenges by the other 
institutions. Helmke and Staton (2011), also explore how courts face counterattacks by the other governmental actors, e.g., the removal of the judges or the packing of the courts.

\section{Courts and Transitional Justice}

The concept of transitional justice elucidates the role of the judiciary during political transitions. Avello (2007) explains how this concept is used to encompass a group of judicial proceedings that are carried out in societies undergoing a transition, most often to democracy. It is a common observation that whenever a society decides to move away from authoritarian to democratic governance, it has to deal with the past sooner or later. This past, full of human rights violations, mass atrocities, genocide, brutal dictatorship, political suppression and other abuses requires a transition from the past to the new democratic reality. According to Avello (2007), the concept of transitional justice dates to ancient Athens, with the trials at Nuremburg and Tokyo at the end of the World War II the origin of modern transitional justice. The trials of former dictators in the 1980s and 1990s in Greece, Argentina, Chile, and South Africa are considered the expansion of the transitional justice in the world (pp. 3-8).

There are two kinds of transitional justice as defined by Huntington (1993). The first is linked to the international level, such as the trials by the Allied forces of the leaders of Axis powers. The second involves internal trails at a national level. As far as the first kind of transitional justice is concerned, Huyse (2009) focuses on how the concept of transitional justice has gone through different changes in history from the late 1940s to the mid-1980s. Initially, the policy was to bury the past and look to the future as observed in both the Khmer Rouge in Cambodia and in Spain after Franco. Similarly, amnesty or impunity for Augusto Pinochet of Chile is another example. The only exceptions were the War Crimes Tribunals at Nuremberg and Tokyo, and the Geneva Conventions of 1945 establishing foundations against impunity. A major 
shift occurred after the dramatic growth of human rights culture in the world, in particular, from the mid-1980s on.

Mihai (2010) discusses two major issues facing transitioning democracies: democracy vs. justice and truth vs. justice. As far as the democracy vs. justice is concerned, there is a consensus among scholars that democracy cannot be established or maintained without handling the past. That said, the emphasis should be on institutional reforms to consolidate democracy, rather than political victimization. The supporters of democracy vs. justice consider that transitional democracies are usually too weak to hold accountable those who benefited from the past dictatorial regime. Therefore, it is essential for the transition to strike a balance between finding justice for past victims and safeguarding the fledgling democracy (Snyder \& Leslie, 2004).

As far as the issue of truth vs. justice, proponents argue that some past crimes demand punishment so as to avoid such abuses in the future. In this pursuit of justice, it is important for the courts to maintain a firm rule of law in order to strengthen nascent democracies, restore order in the society, and to contribute to the dignity of the victims (Minow, 2002; Penrose, 1999).

\section{Judicial Irrelevance}

Ginsburg (2012) describes a possible fourth role of courts in transitioning democracies, when they remain silent or sidelined. He argues the Chilean courts, which were highly professionalized, institutionalized, and formalized, neither supported the dictatorship nor hindered democratization. Rather, they adopted a policy of 'apoliticism,' indicating that they were neither interested in the past, nor the future, instead focusing on narrowly defined current legal questions. Still, the regional trend towards 'rights adjudication' eventually forced the Chilean courts to deal with political matters from the past, giving prominence to rights-oriented litigation, which also changed the views of the legal community. In addition, structural reforms 
that gave more power to the lower courts to decide the legal and constitutional cases brought significant changes in the court system, and the 'complacent' or quiet courts evolved into 'empowered courts' during the consolidated phase in Chile. It is observed that both in Chile and Argentine that once democratization was secured, the courts started to rule against the strong executive.

\section{Courts and their Articulating Roles}

The literature has identified a number of factors that determine which role(s) the courts assume. Ginsburg (2012) focuses on the significance of three elements, space, ideas, and time, in determining the role of judges in various situations. These three elements correspond to the major theories in judicial politics such as strategic, ideational, and historical-institutional. The strategic approach, in particular, focuses on political space rather than time to explain judicial behavior. This approach emphasizes that the power of the courts is determined by the interaction or interplay of various political institutions. Helmke and Rio (2011), endorse this concept by arguing that courts expand their powers during a time of political fragmentation. As far as the prominence of 'ideas' is concerned, Hilbink's argument does make sense in that justice restrains itself from using discretionary powers due to ideational, cultural, and cognitive accounts. Time is the third element, suggesting the changing role of the courts is due to change in the institutional environment.

In a nutshell, the scholars in judicial politics identify four broad roles of the courts in transitioning democracies. In some cases, the courts play the role of an agent of the past by preserving the policies of the prior authoritarian regime. Sometimes, they act as an agent of the future by promoting or consolidating democratic norms in the transitions phase. In some cases, the courts trigger the democratization process through their decisions, encouraging the people 
and initiating the consolidation process. Finally, there are instances where the courts seem to play no role at all, simply reacting after change occurs.

\section{The Role of Activists: Cause Lawyering}

Cause Lawyering is a concept that is focused on lawyers who promote social change for the common good, in particular, for marginalized sections of society by using public interest litigation. There are different forms of cause lawyering throughout the world where the legal community struggled to achieve legal, political, social, civil, and democratic values. According to the literature, lawyering is a widespread concept appearing in stable democracies, newly emerging democracies, and authoritarian settings, however, it is not the same everywhere. It varies from country to country and time to time (Scheingold, 2001). Similarly, some scholars such as Halliday, Feeley, and Karpik (2007) argue for the importance of legal professionals including lawyers and judges in constructing liberal political regimes. The authors note the difference between 'cause lawyering' and 'political lawyering' by developing their own 'legal complex' theories, and analyzing the role of the 'legal complex' in protecting basic human rights in different parts of the world. According to the proponents of this argument, lawyers, judges, prosecutors and other personnel from the legal profession should struggle to establish basic human rights. In this study, I intend to examine the role of the legal community in Pakistan with reference to the expansion of the cause lawyering worldwide, particularly in new emerging democracies. During the Lawyers' Movement, the goals of many legal professionals in Pakistan seemed to be the promotion of democratic values through JI and rule of law.

Kilwein (1997) develops a better understanding of cause lawyering for the lower strata of the community in Pittsburgh, Pennsylvania. He interviewed 29 cause lawyers, both men and women working for the disadvantaged and marginalized people in that city. The major focus of 
the study was to explore the professional and economic impacts of cause lawyering on the respondents. The significance of this piece is its focus on the political dimensions of the cause lawyering. The author divides cause lawyers into different types: 1) individual client lawyering; 2) impact lawyering; 3) mobilization lawyering; and 4) client voice lawyering. He also splits the working styles of his respondents into two categories: one who preferred 'individual client lawyering', and the other who opted for 'combined cause lawyering' based upon a number of social, political and economic reasons. The author also explained the motivational factors behind both styles of cause lawyering such as familial, personal, educational, and when someone joins the legal profession. Cause lawyering for the disadvantaged or marginalized segments of the society does not require formal, organized processes and procedures to do a significant job. It is also true with a large-scale, countrywide social movement like the Lawyers' Movement (LM) in Pakistan where the cause lawyers were loosely organized and had no regular mode or processes and procedures of decision making. The impacts of poverty on cause lawyering were not the same on the respondents, rather they depended on their 'practice style choices.'

Scheingold and Sarat (2004) suggest that it is not possible to define a concept of cause lawyering acceptable for all cross-cultural segments. Both agree with Luban (1988) that lawyers use their professional skills to achieve their social, political, cultural, economic, and legal ideals that ultimately transcend client service. Similarly, ideological ideals animate cause lawyers. Scheingold and Sarat associate cause lawyering with both intent and behavior. Most importantly, cause lawyering is compatible with liberal democratic norms in a society.

Cause-lawyering has multiple forms or types and all have a symbiotic relationship with both democracy and professionalism. The authors further explore: a) the relationship between the cause lawyering and legal profession in historical context; b) the role of legal education in 
inculcating the characteristics of cause lawyering; c) the many sites of cause lawyering, such as public and private, salaried and fee-for-service; d) the roles of cause lawyering in a democracy and its repercussions for the legal profession; and e) the prospects and challenges faced by cause lawyers in global and international perspective where the environment and the resources are different than those in liberal democratic societies such the United States.

Anne Bloom (2008) agrees with Galanter (1983) that the practice 'style' helps to convert an ordinary lawyer into a cause lawyer. However, she believes that cause lawyers are not from particular practice styles. Rather, all cause lawyers are associated with one or another practice styles. According to her, cause lawyers are activists who engage themselves in activities that could help to promote a cause effectively such as publicity campaigns, rallies, marches, and other attempt to get broader support for their cause.

Hilbink (2004) explores the typology of the concept of cause lawyering. He separates ordinary lawyering from politics. According to him, procedural lawyering is one type of lawyering where the lawyers primarily focus on the legal and professional aspects of a case and keep themselves away from partisanship. The second type of cause lawyering, elite-vanguard lawyering, is opposite to procedural lawyering where elite lawyers consider the law as a superior form of politics and they believe in changing the society through changing the substantive law. The third type or category is grassroots, in which the lawyers are skeptical about the law and consider it as corrupt, unfair, unjust, and an oppressive force. Their major purpose is to achieve substantive social justice, but not through courts but through participation in social movements. They also do not seek to play a leadership role in those movements, but instead act as active supporters for the cause of social justice (p. 663). 
I intend to use the preceding discussion of political dimensions and types of cause lawyering to better understand the development and evolution of the Lawyers Movement in Pakistan. Like Epp's (1998) analysis I hope to determine whether the Lawyers Movement produced a support structure for democracy, particularly in the form of a vibrant and activist legal community, along with raising the awareness among the people of their rights.

\section{The Role of Social Movements}

In order to develop a better understanding of the Lawyers' Movement and its social, political, legal, and constitutional impacts, it is useful to examine the most relevant literature and scholarship in the fields of protests, social movements, cause lawyering, and political development. As far as the definitional and theoretical concepts of a social movement are concerned, the Lawyers' Movement was a widespread political and social movement, pioneered by the people in the legal profession, such as cause lawyers and judges, including members of the civil society for the political development of the country.

McCarthy and Zald (1977, pp. 1217-1218) define social movement as a "set of opinions and beliefs in a population, which represents preferences for changing some elements of the social structures and/ or reward distribution of a society.” According to Tilly (Giugni, et al., 1984, p.7), "the term social movement applies most usefully to a sustained interaction between a specific set of authorities and various spokespersons for a given challenge to those authorities." Tilly and Tarrow (2007) present several forms of contentious politics like revolutions, social movements, religious and ethnic conflicts, nationalism, civil rights, and transnational movements. The authors agree that similar analytical tools and principles could be used for analyzing the variety of past and recent episodes of contentious politics. 
Aslanidis (2012) argue that before the late-1960s and 1970s, social scientists considered social and political protest as an irrational reaction of a frenetic citizenry. Later, political and social scientists regarded protest as rational reaction against the excesses of political regimes. There is a voluminous literature on social movements and protests. Political scientists and researchers developed a number of theories and approaches to explain the phenomenon of sociopolitical movements or protests such as collective behavior, mass society theory, and relative deprivation. As far as 'mass theory' is concerned, the alienated, isolated or marginalized groups in the society having no organized channels of participation were left limited to participate in social movements or protests in order to raise their voices. According to the proponents of this theory, protest is the product of socially atomized and marginalized individuals (Arendt, 1951; Buechler, 1993; Jenkins, 1983; Kornhauser, 1959; McAdam, 1982).

In terms of 'collective behavior' theory, classical theorists Gustave Le Bon (1895), Freud (1899), and Durkheim (1897) considered social movements and protest a "visible manifestation of social breakdown" due to the failure of mechanisms that control the socio-political feelings of the people. They focused on psychological variables based on irrational behavior of 'atomized individuals' who wanted to tear apart the social fabric of society (Snow \& Oliver 1995; Useem, 1998; Zald, 1996). Smelser (1962) suggested four important ingredients of collective behavior, structural conduciveness, structural strain, growth along with the speed of generalized belief, and precipitating factors (Smelser, 1962, pp. 15-16). Wallis (1979) defines social movements as "relatively sustained collective efforts to change, maintain, or restore some feature(s) of society or of its members, which employ relatively uninstitutionalised means to promote those ends (Wallis, 1979, p. 1).” 
Contrary to the previous two approaches, mass theory and collective behavior, the 'relative deprivation' theory suggests that protestors were not marginalized with nothing to lose, but were accustomed to a comparatively better life and hoped to increase their well-being more in future through protest and participation in social and political movements (Snow \& Oliver, 1995). According to the proponents of the 'relative deprivation' theory, there are reasons behind this behavior such as aggression, frustration and discontent among the masses (Gurr, 1970; Kerbo, 1982; Gurney \& Tierney, 1982). Although relative deprivation theory is still popular among the researchers and students of SM, it has flaws and weaknesses.

Collective behavior theories also neglected the significance of 'agency.' They considered the social and political movements as spontaneous phenomena which emerged automatically and ignored the role of strategy or deliberate and organized efforts of the movement actors. McAdam (1982) concludes that "social movement is effective not as a political action but as therapy." Most significantly, the major flaw in this 'collective behavior' theory was revealed when different empirical based studies refuted the major claims of this theory, such as the membership in social movements included more well-off individuals compared to the marginalized individuals.

Olson (1965, p. 2) challenged this argument that likeminded people struggle for their common interests by saying: "rational, self-interested individuals will not act to achieve their common or group interests." Olson pointed out the issue of free-riders, asking why do people participate in movements or protests when they can benefit from others coming out and struggling for the common good? There must be some 'incentives' or 'coercive' measures to mobilize the people. He brought a rationalist approach into the collective action phenomenon when people weigh their costs and benefits of their participation in social movements. 
Sociologists and political theorists further elaborated on social movements and protests, enhancing its scope from a psychological microlevel of analysis to the macro-structural level of the society, particularly after the 'new social movements' in the late 60 s and early 70 s around the globe. This movement brought a classical paradigm shift in the field and social theorists developed alternate theories to analyze collective action or social movement phenomenon based on the role of rational actors, available and mobilization of resources, organizations, and networks (McCarthy \& Zald, 1977; Oberschall, 1973).

A new school in the social movement's literature emerged, 'resource mobilization,' that shifted the argument from psychological, personal, irrational, or micro-level analysis to rational, macro- or meso-levels of analysis. According to this school, an organizational mindset and allocation of proper resources were the prerequisites for successful protests. It undercut the basic tenant of the 'collective action' paradigm that 'grievances' and 'shared beliefs' had paramount importance. As far as the definition of 'resources' is concerned, it has very broad implications as Oberschall (1973) observed that "anything from material resources-jobs, income, savings, and the right to material goods and services-to nonmaterial resources-authority, moral commitment, trust, friendship, skills, habits of industry, and so on." Along with the 'resources,' the 'formal organization' headed by a 'mastermind' is also necessary for the efficient use of available 'resources' to achieve success (McCarthy \& Zald, 1977). Similarly, preexisting organizations and social networks play a key role in long-term sustainability of the social movement.

Like 'collective action theories,' the 'resource mobilization' paradigm had its own deficiencies in that it was overly focused on 'economic' and 'entrepreneurial' aspects of social movement phenomenon. A new approach in the field, the 'political process model,' tried to connect the 'missing links' that the early 'collective action' and 'resource mobilization' theories 
left open such as the role of politics or power political elites in shaping mobilization and managing resources, maneuvering the grievances of people and finally creating or exploiting the 'opportunities' to engage into social movements and protests (Jenkins, 1983; McAdam 1982; McAdam, McCarthy \& Zald, 1996).

Eisinger (1973) first introduced the term 'political opportunity structure' while he was studying riots in several major American cities. Tarrow (1998) further elaborated the term this way: that "consistent - but not necessarily formal or permanent - dimensions of the political environment that provide incentives for people to undertake collective action by affecting their expectations of success and failure."

The political process model was further expanded by its pioneers and some other researchers to examine the role of powerful elites and their allies, proponents and opponents, the nature of political institutions, the structures of available opportunities, and the ability of the actors to move forward or restrain themselves (Giugni, 2011; Jenkins, 1983; Lichbach, 1998; McAdam, 1996; Tarrow, 1998; Tilly, 1978; McAdam, McCarthy, \& Zald, 1996). McAdam (1982) synchronized the 'political opportunity structure' and 'resource mobilization' approaches into one theory called the 'political process model.' Both McAdam (1982) and Meyer (2014) considered the resources or 'means' as having the paramount significance in the emergence and development of a social movement. McAdam (1996) said that "political opportunities were simply one of many resources whose availability generally keyed the emergence and development of SM (p. 26)." Similarly, Meyer added that the "structure of political opportunities, is analogous to the structure of career opportunities individuals face, explicitly considered the available means for a constituency to lodge claims against authorities" (Meyer, 2014, p. 127). 
Tilly (1978) combines the attributes of both 'resource mobilization' and the 'political process model', emphasizing four variables: 1) interests; 2) organization; 3) mobilization; and 4) opportunity to establish an alliance between a social movement's elites and institutional actors in order to engage in movement activities utilizing opportunities properly.

As far as the criticism on the political process theory is concerned, the notion of 'opportunity' is not clear in terms of what kinds or forms of opportunities are required for mass mobilization. In other words, when is it best to start a social movement against a government? Theorists and researchers have answers to this query that divide among political elites, existence of political alliances, erosion of the state, and space in the political system which are considered the best opportunity to launch mass movement or protest against the regime (McAdam, 1996; Morris, 2000). Similarly, McAdam, McCarthy and Zald (1996) described the 'mobilizing structures' as "those collective vehicles, informal as well as formal, through which people mobilize and engage in collective action.”

Staggenborg (2015) focuses on the protest cycle of 1960s including women's rights, gay and lesbian rights, the new American right, and the global justice movements in order to understand their tactics, strategies, and organizational challenges including the role of the mass media and counter-movements in determining the outcomes of those movements. Jamison and Eyerman (1991) focus on comparative analyses of the American civil rights movement, environmental movements, and protests in Eastern Europe and the former Soviet Union. The authors stress the importance of social and cultural aspects which help the participants of a mass movement to establish or promote new identities in order to create harmony and unity in a society. 
Polletta and Jasper (2001) examine the role of collective identity in four periods of a social movement such as: 1) creation of collective claims; 2) recruitment; 3) strategic or tactical decision making; and 4) outcomes of the movement. The authors try to find the answers to important questions such as: why do social movements emerge? Why and how are social movements successful? How do the social movements affect the people and their organizations? How and why people are mobilized? How do the participants or activists select targets, strategies, tactics, deliberative styles, and organizational forms from available options? According to them, collective identity has a paramount importance in the process of a protest. Collective identity is different from personal identity. It is also different from common ideological commitment.

Polletta (2002) analyzes the role of participatory democracy in recent social movements in the United States such as the Civil Rights Movement, the New Left, and groups against globalization. This analysis is based upon extensive interviews with activists who participated in these movements at different levels. The major focus of the study is to explore the role or facilitation provided by the participatory democratic model to the activists in terms of coordination, cooperation, information, negotiations, and developing skills, not only to the existing conflict, but to the future scenarios. The author raises some important questions regarding the decision-making process used by the activists during these movements. These probing questions are related to their styles of deliberations, particular tactics, targets, ideological frame, and most importantly the way of making decisions. According to the author, participatory democratic decision-making process can help the social movement groups to affect political and institutional change due to a number of factors, such as the ownership of the decisions, the innovatory and transparent nature of the decisions, and their developmental benefits. Along with 
the advantages of participatory democracy, there are also some disadvantages of the participatory democratic decision-making process such as the slow pace in reaching decisions requires more patience, time, and energy from the participants/activists.

Anwar (2009) considers the Lawyers' Movement as a social movement started by a professional group over a single issue. According to him, the demand for the reinstatement of deposed judges, including the Chief Justice, was viewed as synonymous to the establishment of independence of judiciary in Pakistan and that the movement was not about individuals, but instead focused on the institution of judiciary. He also examines the role of modern communicative means, the private electronic mass media, which gave an opportunity to the legal community to communicate its message. This research is based on focus group discussions (FGDs) with the people from the legal profession in Pakistan. The results of these FGDs show that there was a consensus among the legal community that the main focus of the LM was the restoration of judges intertwined with the ultimate goal of establishing JI and the rule of law in Pakistan.

Tarrow (1998) examines the parameters of the collective action phenomenon or dynamics of mobilization along with the reasons for its failures. He also gives a brief history of how social movements developed in the West in the Eighteenth Century. His major focus is on the 'repertoire' of social movements and their impact on society and their relationship with the statebuilding.

\section{New Social Movements}

The debate over the old and new social movements is as old as the concept itself. The new social movement (NSM) paradigm is primarily based on both macro-historical and microhistorical levels. On the one hand, it concentrates on the role of economic and cultural factors 
behind social movements, and on the other, it studies the role of identity and personal behavior in the present social movement literature.

Millward and Takhar (2019) examine the development of scholarship in social movements and protests, in particular, by sociologists. The authors trace back the history of the literature on social movements and protests stemming from 'collective action' or activism, resource mobilization, rational action theory, political processes and mobilization theories, to the new trend from materially-rooted theories to the NSM based on ideas, and culture. The authors come to the recent developments in mass mobilizations in the form of the anti-globalization occupy movement, the Arab Spring, women's marches against Donald Trump's presidential campaign, the digital revolution through social media, and movements like Black Lives Matter and \#MeToo. According to the authors, issues like racial injustice, sexual abuse, and misogyny have become globally important.

The current outrage in the United Sates against police violence is not new. It started in 2013 from a hashtag created by the activists Patrice Cullors, Alicia Garza, and Opel Tometi. When the court acquitted George Zimmerman of the murder of Trayvon Martin in Florida, the movement started against the police brutality. During the Ferguson, Missouri uprising against the brutal actions of the police department, the slogan of 'Black Lives Matter' became the rallying cry of protestors. The anger against police authorities turned into a mass movement, initially founded by two black women, a number of other factions of the society like feminists, LGBTQ activists, organized labor, low income working groups, and social media activists. The members of this movement kept away from the traditional old guard of the Civil Rights movement, like Jesse Jackson and Al Sharpton, and from the American political establishment (Rickford, 2016, pp. 35-37). 
The recent murder of George Floyd in Minneapolis, Minnesota by a white police officer gave new impetus to the Black Lives Matter movement and has almost attained global attention. It has become a massive mass movement for the safety of the black people in the world, particularly in the United States, asking for justice and far reaching policing reforms. The movement against the mistreatment of black people in America is expanding not only in the US, but the other countries of world as well. It is inspiring African American youth and awakening the spirit of racial equality, solidarity, and equity (Brownstein, 2020).

There is voluminous literature on the role of social movements, mass protests, and causelawyering. The literature on social movements and new social movements also focus on the, causes, procedures, resources, and the types of mass mobilizations and the role of individuals and organized groups in order to motivate common people. However, the vast literature has examined the social movements and their roles including their impacts in the Western countries, in particular, the Latin American nations. The research in this study to explore the causes, resources, mobilization of the legal community and its impact on the democratic system of Pakistan and on Pakistani society as a whole is grounded in the literature on social movements.

\section{Conclusion}

In this chapter I identify the concepts of democracy, transitional democracy, the different roles of the courts in different kinds of regimes such as developed democracies, authoritarian regimes, and transitional democracies like Pakistan. I identify that both democracy and the judiciary are in transition in Pakistan. I also identify the five major roles of the courts in transitioning democracies: 1) as upstream triggers of democracy; 2) as downstream guarantors; 3) as downstream democratic consolidators; 4) as judicial irrelevance; and 5) as articulators. I 
also introduce work on cause lawyers and social movements relevant to understanding transitions to democracy in polities like Pakistan. 


\section{Chapter 3}

\section{Methodology}

\section{Introduction}

My dissertation focuses on three important research questions. First, it examines the development of the judicial system in Pakistan, paying special attention to the status of judicial independence from 1947 to 2007. Second, it analyzes the Lawyers’ Movement, a social movement that took place from 2007 to 2009 that sought to transform the judicial system in Pakistan and to bring broader fundamental change to the whole of government. In this part of the study, I analyze the movement, explore how it organized and operated, and examine the group's goals, including to what degree its leaders were concerned with judicial independence. Third, my study examines whether the Lawyers' Movement altered the political status of the judiciary, again, paying attention to the status of the courts' independence.

To answer these questions, I use mixed methods that rely on existing documentary sources and original qualitative data drawn from interviews with legal elites and movement activists. In this chapter I explain how I collected these qualitative data. Since the concept of judicial independence is part of my research, I begin this chapter by reviewing the literature in terms of how other scholars have measured this concept.

\section{Measuring Judicial Independence}

As discussed in chapter 1, judicial Independence (JI) is commonly viewed as an important feature of modern liberal democracies. There is a consensus among scholars that JI contains three significant features: impartial justices, respect for their decisions, and noninterference in their affairs. JI is a complex phenomenon to define and measure (Cross, 2008; Rosenn, 1987). It is different in various types of political systems such as stable democracies, 
authoritarian regimes, and transitional democracies (Russell \& O’Brien, 2001). There are also different meanings to the term JI in different types of regimes based on both the de jure, and de facto role of the judges and the courts (Rios-Figueroa, 2006). The various models of judicial decision making--legalist, attitudinal, and strategic - further complicate the definition of judicial independence (Stephenson, 2003).

Scholars have used different methods to measure the independence of the judiciary. For example, Feld and Voigt (2003) distinguished between de jure independence and de facto independence. They developed a scheme to establish indicators of both forms in order to test its impact on the economic growth of 57 countries. The authors developed their measure through a survey of experts in 71 countries. There are twelve variables measuring de jure independence and eight variables measuring de facto JI. As far as the de jure indicators of JI are concerned, most relate to textual or constitutional guarantees like stability of constitutional provisions, appointment procedures, rules on judicial tenure, salaries, accessibility to the courts, allocation of cases to judges, judicial review, and publishing the decisions courts (Feld \& Voigt, 2003, pp. 501-503). Indicators of de facto independence include the effective term length of the judges, the internal influence of judges as colleagues, the financial autonomy of both judges and the courts, frequency of rule changes, and the relationship or cooperation of other branches of the government. Feld and Voigt conclude that de facto independence has a robust, significant and positive impact on economic growth, while de jure had no impact (Feld \& Voigt, 2003, pp. 503504).

Other researchers have conducted large, cross-national studies of judicial independence, including Rios-Figueroa and Staton (2014), Linzer and Staton (2015), Dijk and Vos (2018), and Keilitz (2018). In these and other studies, researchers explore the status of judicial independence 
and its impact on economic growth, regime stability, the protection of human rights, corruption, and institutional accountability (Gibler \& Randazzo, 2011; Keilitz, 2018; La Porta et al. 2004; North \& Weingast, 1989).

Rios-Figueroa and Staton (2014) describe de jure JI as institutions that insulate judges, while de facto independence is found in judicial behavior and influence. Colon (2003) explored the work of Latin American scholars on the indicators of the judicial independence and summarized them into eight categories: 1) the appointment process of the judges; 2) salary protection; 3) life tenure of judges; 4) professional qualification of judges; 5) judges' involvement in the judicial discipline, i.e., accountability of judges by themselves; 6) financial autonomy; 7) fixed numbers of judges of the superior court and; 8) functional autonomy from the other branches of the government. According to Colon, greater involvement of the judiciary in the above-mentioned matters ensures greater judicial independence (Colon, 2003, p. 109).

Colon adds to these indicators with what he calls constitutional powers variables that deal with the independence of the judicial branch from the other branches of the government. These thirteen variables are mostly related to constitutional provisions regarding the decrease or increase in judicial independence. Six variables enhance judicial independence: 1) judicial review; 2) a supreme court's powers to certify proposed legislation including the appointment of its own judges; 3) prohibitions against the other branches of the government interfering with judicial functions; 4) powers given to the other branches of the government to enforce the judgments of the Supreme Court; 5) delineation of exclusive powers of the Supreme Court to resolve disputes; and 6) explicit constitutional powers given to the Supreme Court to initiate legislation/policy to operate. Colon identifies seven common constitutional provisions that are designed to, or have, the impact of discouraging or eliminating judicial independence: 1) 
reserving the power of other branches to self-judge the constitutionality of their acts; 2) setting limits on the judicial review powers of the supreme court; 3) setting super-majority thresholds for court decisions to become precedent; 4) giving powers to the legislature to alter the jurisdiction of the supreme court; 5) giving powers to the legislature to limit the applicability of supreme court decisions; 6) establishing courts whose decisions may not be reviewed by the supreme court, and 7) constitutional provisions for the other branches of the government to issue decrees, pardons, or states of siege independently of the courts (Colon, 2003, pp. 119-120).

Dijk and Vos (2018) examine European court systems to measure judicial independence and accountability. The authors divided the indicators of judicial independence into two major categories: formal and perceived, or de jure and de facto. Ultimately, they focus on thirteen indicators of JI: 1) legal or constitutional independence; 2) organizational independence; 3) financial independence; 4) managerial independence; 5) control over human resource decisions; 6) control over disciplinary procedures, i.e., a competent body established under the ENCJ procedures to make judges accountable ; 7) non-transferability, i.e., a formal guarantee to the judges not be transferred without their prior consent ; 8) internal independence; 9) subjective independence as measured by public opinion; 10) subjective independence as measured by court users; 11) subjective independence as measured by judges themselves; 12) judicial corruption as perceived by the public; and 13) the public's relative trust in judiciary (Dijk \& Vos, 2018, pp. 811).

Linzer and Staton (2015) have presented a cross-national measure of de facto JI covering 200 countries from 1948 to 2012 including Pakistan. The time period of this study covers both periods in Pakistan, i.e., before and after the Lawyers' Movement 2007-2009. The figure A1 regarding the results of the estimates of judicial independence show an increase in the judicial 
independence in Pakistan after the Lawyers' Movement (Linzer \& Staton 2015, p. 249). The authors offer a measurement model called TSCS, i.e., time-series, and cross-sectional model to measure the latent Judicial Independence for 200 countries since 1948 to 2012. First, the authors adopted the division of the concept of JI in the previous literature into two parts, de jure and de facto. However, the authors also made the distinction between the autonomy of judiciary and its powers based on the separate roles of the judges as individuals and the role of judiciary as role of judges collectively or as an institution.

According to Linzer and Staton (2015) judicial independence in Pakistan goes up and down from 1948 to 2012, however, their study does not conclude why judicial independence goes up after the Lawyers' Movement which is the crucial part of my work in this study. They made a general analysis of judicial independence across the world of more than 200 countries, however, the qualitative analysis in my study covers one major objective measure, i.e., of judicial independence in Pakistan, the historic Lawyers' Movement.

All methods have limitations, therefore, scholars often recommend and apply a multiple methods approach to analyze social phenomena (Denzin, 1970; Web, 1970). According to Creswell (2009, p. 12), the quantitative research method has an advantage to explore and analyze numerically and statistically the attitudes, behaviors, and opinions of sample or targeted population in the study. However, the qualitative research technique has the ability to highlight the relationship or interactions among the various actors or players based on their personal, local knowledge and experience. Scholars suggest using both quantitative and qualitative methods side by side in order to explore both numerical and data-based analyses of social problem and to develop a better understanding of the issue through real-life experience of the participants in the study (Creswell, 2004, p.14). 
In this study, I use face-to-face interviews of 30 elites closely and directly associated to the Lawyers' Movement, as well as a survey, and documentary sources. I sent to the respondents the structured interview schedule and survey by mail and by hand. Before sending the questionnaire and survey I contacted each respondent to ensure their willingness and ability to participate in the project. I also sent a cover letter issued by my dissertation chair explaining the research topic along with its purpose and significance, with a paragraph ensuring them anonymity (a copy of the letter enclosed as annexure A). As suggested by scholars (Aberbach and Rockman, 2006; Creswell, 2009; Dodge, Ospina, Foldy, 2005; Ospina and Dodge 2005), the main purpose of face-face interviews was to understand the opinions and perceptions of participants about their roles, communication, and interactions. The in-depth information I gathered about the concepts, the Lawyers' Movement, its goals, and the status of judicial independence before and after the LM, and most importantly, the impact of this social movement on country's judicial system and society could come from any source other than the face-to-face interviews and a survey.

\section{Survey Instruments and Methodology}

For my study, I collected data from key elites inside and out of the judiciary of Pakistan. I collected these data in two ways. First, I conducted in-depth, face-to-face interviews with thirty individuals. Second, I developed an instrument designed to measure judicial independence in Pakistan before and after the Lawyers' Movement. Participants who participated in the interviews were also asked to complete this Pakistan JI instrument. In this section, I introduce both the interview schedule and the JI instrument and describe how I conducted my research. 


\section{Elite Interviews}

Interview Participants - I interviewed thirty respondents who were either closely associated with the Lawyers' Movement, or are prominent members of the legal community, or are noted observers of the Pakistan justice and political systems. These men (27) and women (3) are retired judges, lawyers, professors, politicians, journalists and others. I could not interview current judges because according to Pakistani law sitting judges are not allowed to express their views in an interview unless they been have retired from active service for at least two years.

Among my respondents were three retired justices of the Supreme Court of Pakistan. The interviews took place at the residences of two justices; the other was with a retired justice who taught at a prominent Pakistani law college of law. The duration of interviews varied between forty minutes to one hour. I interviewed one former Chief Justice of a High in his chamber. I also interviewed four retired justices of the High Courts. I met three of them at their homes. One justice out of four was a PCO judge whom I met at his chamber. I interviewed four top leaders of the Lawyers' Movement all of whom were also renowned lawyers at the Supreme Court of Pakistan. One of them later became a justice of a High Court. Two out of five Supreme Court lawyers I interviewed had also served as Federal Law Ministers at various times, one in President General Ayub Khan's cabinet and the other in General Pervaiz Musharraf's cabinet. One of them was also a member of the Judicial Commission responsible for the appointment of judges. One of them is also a renowned author of dozens of books on law, the judiciary, and courts in Pakistan. As far as the lawyers of the Supreme Court are concerned, I interviewed both supporters and opponents of the Lawyers' Movement in order to get a balanced and unbiased data.

I interviewed two politicians, one of whom was the General Secretary of a major religious political party in Pakistan. The other served as a Federal Minster, had been a former Chairman of the Senate which is the upper house of the Parliament, and had also served as the 
Chairman of the Parliamentary Committee which drafted the Eighteenth Amendment of the Constitution. This amendment brought major changes in the appointment process of the judges of the superior courts. I met him in his office at the Parliament House, Islamabad, and the federal capital of Pakistan.

Four participants in this study are renowned and senior journalists. All four publish regular columns in the top national newspapers of the country. Two of them are also the owners and chief editors of their newspapers/magazines. Two of them host their own popular primetime television talk shows on two major cable network news channels. I interviewed two of them at their homes and the other two in their offices. One of them has six decades of experience of writing for the editorial page of his newspaper.

I conducted interviews of five professors from the fields of law, political science, and history. All interviews were conducted at their work places, i.e., offices, except one professor of history whom I met at his residence. Two professors of law were also the principals (deans) of law colleges, one in the private sector, and the other in the public sector. Similarly, I interviewed three professors of political science, one retired from a public sector university, one professor and dean of a public sector university, and the other from one of the major private sector university in Pakistan. I interviewed a professor of Islamic Studies in his capacity as a representative of the teaching community in the Lawyers' Movement. I also interviewed a representative of social active non-governmental organization.

Primarily, the respondents were selected based on purposive and convenience sampling methods, however, the recommendations and guidance provided me by dissertation committee at the time of my prospectus defense helped me to select the most relevant people. Among these elite interviewees, most of them were highly associated with the Lawyers' Movement either as 
an active participant or a close observer of this historic event. All of them were in high positions in their respective fields.

All of my participants agreed to my audio recording of their interview with the exception one judge of the High Court; I took notes for his interview. As Clark (2011) points out in his book "The Limits of Judicial Independence," there are difficulties and hurdles in conducting in elite interviews. According to him, the method of elite interviews is not a science but an art. Most importantly, for an academician to gain access to the elites is quite unlikely and then to be able to successfully interview them is a pretty difficult task (Clark, 2011, pp. 271-272).

Survey Instrument - The qualitative analysis of these interviews is highly significant in this study in terms of understanding the opinions and observations of the most relevant and concerned people associated with the Lawyers' Movement. The questions in the survey instrument are designed to tap into the respondents' knowledge and experiences regarding the historical development of judicial system, the relationship of the Lawyers' Movement with the concept of independent judiciary, and the future prospects of an independent and free judiciary in Pakistan.

The survey instrument was formulated with the approval of my dissertation committee chair and the committee members. Initially, there were twelve to fifteen questions in the tentative interview schedule. A few more questions were added with the approval of the committee chair in order to explore comprehensive roles of the respondents in the Lawyers' Movement. Most of the questions were directly linked to the major research questions in the study, however, a few supplementary questions also asked for greater clarity of the concepts presented in the study. The supplementary questions were also necessary to be asked from the participants in the context of all activities relating to the Lawyers' Movement that were important for this study. 
The questionnaire consists of twelve major questions including thirteen sub-questions.

Those in bold are the major questions and those that are italicized are supplementary questions.

1-How do you perceive the concept of democracy?

2-What do you see is the role of judiciary in a polity/democratic state, particularly a transitioning democracy like Pakistan?

a) In your opinion, what are the bases of rule of law?

b) What should be the place of religion in law?

\section{3-How do you perceive the concept of judicial independence?}

4-In your opinion what was the status of Judicial Independence in Pakistan before March 2007?

a) In your opinion, what were the major factors which eroded the judicial independence in the past in Pakistan?

b) How was the Lawyers' Movement started?

c) Who were the progenitors and opponents of this movement? And who were the leaders?

d) How masses were mobilized? Most importantly, how this Movement was sustained for more than two consecutive years despite so many difficulties including the financial?

5-What were the main objectives of the Lawyers' Movement?

a) What was the relationship between the objectives of the Lawyers' Movement and Judicial Independence in Pakistan?

b) Has the Lawyers' Movement achieved its goals? If yes how, if no why?

6-In your opinion what has been the status of Judicial Independence in Pakistan after the Lawyers' Movement?

a) After the 18th amendment in the constitution, how do you evaluate the appointment process of the judges?

b) How do you evaluate the removal methods of judges of superior courts?

c) Judicial accountability is an important part of a strong democratic system, how do you rate the accountability of judges in Pakistan?

7-What do you think about the overall impact of the Lawyers' Movement on the judicial system of Pakistan? 
a) What do you think about the impact of Lawyers' Movement on Judicial Independence in the future?

b) With reference to the new code of the judges, could the current judiciary be seen as a bulwark against any future military adventure in Pakistan?

8-Did the Lawyers' Movement change the nature of relationship between the judiciary and the other branches of the government, the executive, and the legislature?

9-Has this movement enhanced the image of judiciary among the general public?

10-What is the overall impact of this movement on Pakistani society?

11-What would you suggest to improve the judicial system of Pakistan?

12-What would you suggest to improve the democratic health of Pakistan?

The literature review revealed that the questions regarding the status of judicial independence before and after the Lawyers' Movement in Pakistan were missing from past work. The best way to get the information required is to ask directly from the most relevant people through the interviews and the survey (Aberbach \& Rockman, 2006). In order to get diverse opinions, I interviewed divergent section of the people both for and against the Lawyers' Movement. I have analyzed and included the excerpts of those interviews in four of my study's five chapters. First, I transcribed all interviews and read them carefully before choosing the excerpts to analyze the answers of the questions.

\section{Pakistan Judicial Independence Instrument}

Based on the literature on judicial independence discussed above, I developed an instrument to assess how, if at all, my elite respondents feel that the Lawyers' Movement had an impact on the Pakistani polity, the judicial system, and judicial independence (see Table 6.1). At the conclusion of each in-depth interview, I presented this JI instrument to the respondent and asked her or him to complete it. Most of the respondents completed the survey immediately and handed it back to me, however, some of them completed it later and returned it to me by mail. 
As Table 3.1 shows, I made two columns: 1) the state of JI before the Lawyers' Movement; and 2) state of JI after the Lawyers' Movement, and gave respondents four options to mark in front of each indicator of JI, by using a scale with four options: a) poor, b) fair, c) good, and d) excellent. All thirty respondents completed this survey. I applied the Paired Samples T Test to analyze data of the survey, not only to measure the status of JI before and after the LM, but to make a comparison of both periods and more importantly, to test the impact of the LM on the whole judicial system of Pakistan, including the independence of judiciary.

This study is exploratory in nature. The interview schedules were designed to tap into the belief or perceptions of the participants regarding the key concepts in the study such as democracy, transitioning democracies, judicial independence, and the social movements. Similarly, the meanings and nature of these concepts has also been explored from the existing literature in the relevant areas of research. 


\section{The Indicators of Judicial Independence}

Table 3.1 (The State of Judicial Independence before and after the Lawyers' Movement)

\begin{tabular}{|c|c|c|c|c|c|c|c|c|}
\hline \multirow[t]{2}{*}{ Indicators } & \multicolumn{4}{|c|}{ Before March 2007} & \multicolumn{4}{|c|}{ After March 2009} \\
\hline & Poor & Fair & Good & Excellent & Poor & Fair & Good & Excellent \\
\hline $\begin{array}{l}\text { 1. Authority of judicial } \\
\text { review }\end{array}$ & $\square$ & $\square$ & $\square$ & $\square$ & $\square$ & $\square$ & $\square$ & $\square$ \\
\hline 2. Appointment of judges & $\square$ & $\square$ & $\square$ & $\square$ & $\square$ & $\square$ & $\square$ & $\square$ \\
\hline 3. Qualification of judges & $\square$ & $\square$ & $\square$ & $\square$ & $\square$ & $\square$ & $\square$ & $\square$ \\
\hline $\begin{array}{l}\text { 4. Retention methods of } \\
\text { judges }\end{array}$ & $\square$ & $\square$ & $\square$ & $\square$ & $\square$ & $\square$ & $\square$ & $\square$ \\
\hline $\begin{array}{l}\text { 5. Removal methods of } \\
\text { judges }\end{array}$ & $\square$ & $\square$ & $\square$ & $\square$ & $\square$ & $\square$ & $\square$ & $\square$ \\
\hline $\begin{array}{l}\text { 6. Jurisdiction of the } \\
\text { courts }\end{array}$ & $\square$ & $\square$ & $\square$ & $\square$ & $\square$ & $\square$ & $\square$ & $\square$ \\
\hline 7. Number of judges & $\square$ & $\square$ & $\square$ & $\square$ & $\square$ & $\square$ & $\square$ & $\square$ \\
\hline 8. Administrative powers & $\square$ & $\square$ & $\square$ & $\square$ & $\square$ & $\square$ & $\square$ & $\square$ \\
\hline $\begin{array}{l}\text { of judges } \\
\text { 9. Pay/salaries of the } \\
\text { judges }\end{array}$ & $\square$ & $\square$ & $\square$ & $\square$ & $\square$ & $\square$ & $\square$ & $\square$ \\
\hline 10. Term of office & $\square$ & $\square$ & $\square$ & $\square$ & $\square$ & $\square$ & $\square$ & $\square$ \\
\hline 11. Financial autonomy & $\square$ & $\square$ & $\square$ & $\square$ & $\square$ & $\square$ & $\square$ & $\square$ \\
\hline $\begin{array}{l}\text { 12. Relationship with } \\
\text { executive }\end{array}$ & $\square$ & $\square$ & $\square$ & $\square$ & $\square$ & $\square$ & $\square$ & $\square$ \\
\hline $\begin{array}{l}\text { 13. Relationship with } \\
\text { legislature }\end{array}$ & $\square$ & $\square$ & $\square$ & $\square$ & $\square$ & $\square$ & $\square$ & $\square$ \\
\hline $\begin{array}{l}\text { 14. Relationship with the } \\
\text { military }\end{array}$ & $\square$ & $\square$ & $\square$ & $\square$ & $\square$ & $\square$ & $\square$ & $\square$ \\
\hline 15. Public opinion/support & $\square$ & $\square$ & $\square$ & $\square$ & $\square$ & $\square$ & $\square$ & $\square$ \\
\hline
\end{tabular}




\section{Conclusion}

This research is a mixed method study that uses qualitative, quantitative, and documentary work to provide evidence to help answer three major research questions regarding the status of judicial independence in Pakistan before and after the Lawyers' Movement. This study includes 30 elite interviews of the people highly associated with the historic Lawyers' Movement 2007-2009. This study also includes a survey having 15 indicators of judicial independence filled out by these thirty elite participants.

I recognize that there are challenges in understanding the concept of judicial independence. There is no single definition of the concept in the literature and similarly no consensus on how to measure judicial independence. However, there is voluminous literature debating both definitional issues and the methodology regarding the measurement of the concept. Both international and regional or national organizations have also developed the tools and processes to evaluate the status and role of judicial independence across the globe. These researchers have also benefited from the data collected and managed by international and national, governmental and non-governmental organizations.

While I benefit from this prior research, my study applies it to the unique social and political nature and conditions of Pakistan. I come to the conclusion that the mixed methods approach has allowed me to take stock of the change in the judicial structure of Pakistan due to a massive scale social movement of cause lawyers, judges, and other segments of the civil society. 


\section{Chapter 4}

\section{The Judiciary in Pakistan: From 1947 to 2006}

\section{Introduction}

In this chapter, I use the literature on courts in transitioning democracies to document the development of the judiciary in Pakistan, with particular attention to how they function and what kind of relationship they have with other governmental and societal actors. I am particularly interested in determining the conditions under which they work independently and their impact on the democratic health of Pakistan. This chapter also explores the status of judicial independence in Pakistan before and after the Lawyers' Movement. This chapter consists of four major parts: 1) an examination of the courts of Pakistan in historical perspective; 2) an analysis of the de jure role of the courts in Pakistan; 3) an examination of the de facto role of the courts in Pakistan and 4) and a comparison of the role of the courts in both military and civilian regimes. In addition, this chapter highlights the factors which determine, more often than not, that the courts play a subservient role in the polity.

\section{Courts: Historical Perspective}

Pakistan's judicial system is an amalgam of a variety of influences including the Hindus, Mughals, and British colonial rulers. Pakistan’s judicial system has evolved through four distinct eras: the Hindu Kingdom, Muslim rule, the British colonial era, and the period after independence after the partition of India in August 1947. The British period has had the greatest impact on the structures and functions of the court system (Hussain, 2015, p.1)

\section{The Hindu Kingdom}

The Hindu period ranges from $1500 \mathrm{BC}$ to $1500 \mathrm{AD}$. Key ancient texts such as Dharamshastra, Smiritis and Arthashastra, and the commentaries made by contemporary 
historians and jurists, are the main sources of judicial rule in this period. While the judicial system was well defined and elaborate, the Hindu King or Emperor had absolute control over the judicial process. There were officials appointed by the King like judges, ministers, or councilors to assist the ruler in order to administer justice, but the final judicial decision-making powers were in the hands of the King. The courts were established at two levels, central and local. At the central or capital, the highest court was the Chief Justice's Court at the Capital of the realm. The decisions of this court could be challenged in the King's Court. The justices were appointed by King himself on the basis of their qualifications or experience and their class or caste, as most of them were 'Brahmins.' The Hindu King had the power to overrule the decisions of the Chief Justice's Court (Hussain, 2015, pp. 1-2).

As far as the local level is concerned, there was a 'village council' or the assembly of the people headed by a headman or 'Serpunch.' It was a kind of a 'village government' referred to as 'Punchayat' and performed multiple executive or administrative, religious, and financial functions. However, the foremost duty of this organization was to administer justice. Both civil and criminal issues were presented before this body. There were as such no written or codified laws or rules and decisions were taken on the basis of morality, customs, and usages/tradition, mostly associated with the religious teachings and cultural taboos (Tinker, 1968, pp. 19-20).

The procedure of the court was similar to the American jury system, the claimant/plaintiff filed the suit or claim before the body and the other party, the defendant would present a defense and both were allowed to present proof in the form of their witnesses in the court (Punchayat). An appeal against the decisions of the Punchayat could be filed in the next higher court and finally in the King's Court. While the current court system in Pakistan is certainly more complex, the current hierarchy is not much different from that which was used in ancient India 
by the Hindu rulers. These ancient courts had no freedom to act freely but to protect only the rights of the upper classes of the society (Hussain, 2015; Khan, 2009; Long, 2015; Tinker, 1968).

\section{The Mughals}

The early Muslims came to India as traders and sailors in the ports of the western coast. The first Muslim conquest under the leadership of Muhammad Bin Qasim was made with the invasion of Sindh in 712 AD. Delhi, the capital city, fell to the Muslims when Shahabuddin Muhammad Ghouri defeated the Hindu Rajput ruler Prithwiraj Chauhan in 1192 AD. The first Muslim dynasty/Sultanate was established by Sultan Qutubuddin Aibak in 1206 AD. The Muslim Rule in India can be divided into two phases: 1) the early period ruled by Muslim Sultans until 1526 when another Muslim dynasty, the Mughal dynasty was founded by the first Mughal Emperor Zahiruddin Babar which lasted until the demise of last Mughal Emperor Bahadur Shah Zafar in 1857 when the British colonial administration took the full control of India (Hussain, 2015, pp. 2-3).

During this period, the Muslim rulers did not impose Sharia law or religious law on all sections of the society. Both the Islamic law and customary law or local traditions were followed to decide civil and criminal disputes. Akbar the Great (1556-1605) introduced secular laws for the non-Muslim population (Long, 2015, pp. 245-247). He prohibited the collection of an Islamic tax called 'Jizya' from non-Muslim population. Similarly, cow slaughter was declared illegal to appease the vast Hindu majority. The country was divided into five levels of administrative units or tiers: central, provincial (Suba), districts (Sarkar), and Tehsil (Pargana), and the lowest level of courts was at the village/town level. There were four types of courts under the Muslim period, the central court or King's court in the capital, the final court of appeal having both original and appellate jurisdiction. The King had all powers to appoint judges of caliber, repute, integrity, and 
competence. The judges could hold office as long as they enjoyed the confidence and pleasure of the King. The second tier was the Court of Nazim-e-Suba (Provincial Chief). The head of the provincial administration was the presiding officer of the court system at the provincial level. Similarly, the court at the district level was headed by the judicial officers called Qazis. At the Tehsil level, there were courts headed by Qazis, as well (Khan, 2009, pp. 3-4).

The most distinguished and important courts were at the village level and these courts, the Punchayats, were the ancient courts started under the Hindu rulers and were retained throughout the whole Muslim period. The Punchayat or Elder Council was an important executive, administrative, and judicial unit at the village level, composed of influential people of the village or society, in particular, those belonging to the rich families of higher castes such as Brahmins. The major function of the councils was judicial and they decided both civil and criminal matters.

Apart from the aforementioned four tier courts system, there were other individuals and institutions that performed both, administrative and judicial functions at the same time. For example, there was an elaborate system of revenue collection at the four levels of the government. There were also some officials at the local level who had performed various judicial duties in order to resolve both civil and criminal disputes such as Foujdar, Kotwal, Shiqdar, and Subedar (Shah, 1986, p.99).

There were both written laws and orders issued by the King or his appointees (Fermans) and unwritten customs or traditions that provided the bases for quasi-judicial independence. Quasi because the jurisdiction of different courts was not well defined, in particular, the appellate jurisdiction was unclear, allowing plaintiffs to take their cases to the higher courts of their own choice. Compounding the conditional nature of judicial independence was the reality that the 
higher or appellate courts would hear cases without considering the proceedings and judgments of the lower courts i.e., the lower courts had very little independence compared to the higher /appellate courts (Hussain, 2015, p. 3).

\section{British Colonial Government}

On December 31, 1600, Queen Elizabeth I granted a charter to the Governor and a company (East India Company) of merchants of London to trade in the East Indies. Other than the power to legislate, the Charter gave the Governor and the Company the power to enforce laws over its employees. King James I renewed the Charter in 1609. King Charles II issued a new Charter in 1623 and gave powers to the East India Company to establish its own courts for both civil and criminal cases involving its employees. The Charter of 1661 further expanded the jurisdiction of the courts to all residents at the settlements of the Company other than its own employees (Hussain, 2015, p.4). The Charter of 1661 also changed the nature of the company from a trading or commercial entity to a territorial political power.

Initially, the British government established courts for three towns, Bombay, Calcutta, and Madras. There were two kinds of courts, the Supreme Court and the Recorder's Courts, staffed by British judges appointed by the Crown. Both civil and criminal cases were decided using British law. Non-British citizens came under the jurisdiction of other courts (Sadar Dewani Adalat and Sadar Nizamat Adalat) which applied local laws and regulations in their decisions. By 1823, under the Regulation Acts of 1773 and 1798, and the Act of the Parliament of 1823, British Supreme Courts were established in the cities of Calcutta, Madras, and Bombay, which consisted of Chief Justices of each Court and other Associate Judges (Hussain, 2015, pp. 3-4).

The High Court Act of 1861 replaced the Supreme Courts and Sadar Courts/Adalats with the High Courts in Presidency Towns and expanded to Allahabad in 1866, Patna and Lahore in 
1919, and Rangoon in 1936. By the Sind Courts Act of 1926, the British government established the Sind Chief Court. Similarly, the North West Frontier Province Courts Regulation of 1931 and the British Baluchistan Courts Regulation of 1939 established the Court of Judicial Commissioner in these areas. The Code of Civil Procedure of 1908 had already established the principal civil courts such as the Court of District Judge, the Court of Additional District Judge, the Court of Civil Judge, and the Court of Munsif at various levels of local administration such as Tehsil and District levels (Khan, 2016, pp. 10-15).

\section{The Government of India Act of 1935}

Before partition of India into two independent states in 1947, the British ruled India under the India Act passed by the British parliament in 1935, referred to as the India Act of 1935. This Act provided a federal form of government. The executive authority was vested in the Governor General appointed by the British Monarch. He would exercise his powers with the aid of his appointees in the Council of Ministers (Marri, 1990, p. 11). This Act established two chambers of legislatures, the Council of State, and the House of Assembly along with His Majesty represented by the Governor General himself. According to the Section 32 of the Act, the legislature would pass a law with the assent of the Governor General. For the administration of justice, the Act of 1935 established a Federal Court that had original and appellate jurisdiction. It also established at the provincial level, High Courts, the Chief Courts and the Judicial Commissioner's Courts with both original and appellate jurisdictions. Under Section 208 of the Act of 1935, the procedure was laid down for the appeal of a decision of the Federal Court to His Majesty in Council, the Privy Council (Amin, 2015, pp. 107-108). As such, courts under the act were semi-autonomous. In practice, the courts under the British rule were autonomous and enjoyed freedom of action without outside interference in their affairs. 
The India Act 1935 restructured the court system in India. It retained the previous High Courts along with the establishment of a Federal Court having original, appellate, and advisory jurisdiction. The Federal Court had the power to decide disputes between the Federal Government and the Provincial Governments (Kazimi, 2009, p. 129). In terms of staffing the courts, the British Crown had the powers to appoint the judges of the Federal Court. The prescribed qualifications for the judges of the Federal Court were: 1) five years of experience as a High Court judge; and 2) ten years of experience as a barrister or pleader in a High Court. The mandatory retirement age of the judges was 65 . The judges of the Federal Court and High Courts enjoyed independence and freedom and they could not be removed from their duties unless the Judicial Committee of the Privy Council recommended on the reference made by the Crown (Hussain, 2015, pp. 4-5). All of the preceding gave the judiciary the grounds for de jure independence.

\section{The Independence Act of 1947}

In this study, I examine the de jure independence of the courts in Pakistan since its first interim Constitution, the Independence Act of 1947. After the independence of Pakistan on August 14, 1947, the Government of India Act 1935 continued in force in Pakistan along with the Independence Act of 1947. The Independence Act of 1947 was passed by the British Parliament. The Government of India Act remained the first constitution of independent India until her own constitution was adopted in 1949. Both of these acts formed the Interim Constitutional framework of the newly independent States of India and Pakistan until the adoption of their own constitutions later in 1949 and 1956 respectively (Munir 2014, pp. 8-9).

Section 8 (2) of the Act of 1947 stated, “...each of the new Dominions and all Provinces and other parts thereof shall be governed as nearly as may be in accordance with the Government 
of India Act, 1935 and of the Orders in Council, Rules and other Instruments made thereunder." Section 8 (1) of the Act of 1947 provided that, “...for the purpose of making provisions as to the Constitution of the Dominion," i.e., the new dominions of India and Pakistan, those states were given the authority to make their own constitutions by their respective assemblies.

CJ Sir Mian Abdul Rashid pleaded for the autonomy of the Federal Court of Pakistan and observed:

An autonomous Judiciary is the essence of Independence. Now that Pakistan is an independent Sovereign State, it is in the fitness of things that all appeals that are at present entertained by the Privy Council should be transferred to the Federal Court of Pakistan. I hope the necessary legislation for this purpose will be undertaken by the Constituent Assembly at early date. The Dominion of India abolished Privy Council appeals as long as February 1948 (Khan, 2016, p.19).

Pakistan got the lessons of law and judiciary from the British experience and adopted the common law tradition like other Commonwealth nations, however, there are tremendous differences in terms of how courts in the United Kingdom and Pakistan function. Prime among these is the written Constitution of Pakistan which has supremacy over other ordinary laws in the country contrary to the British practice having no written constitution and no difference between the constitutional law and the ordinary law (Neudorf, 2017, p. 128).

\section{The Constitution of 1956}

On March 23, 1956, Pakistan adopted its first constitution. It took nine years to frame the Constitution and two legislative Assemblies struggled to meet this challenge. It contained six schedules and 234 articles. The system of government developed was federal and powers were divided between the federal and provincial governments. The Constitution contained three lists of powers, one for the federal government to make laws, the second pertained to the matters related to the provinces, and the third, called the concurrent list, was composed of the matters where the federal and provincial governments shared concurrent powers to make law. In the case 
of a dispute between the central law and the provincial law, the central law was supreme (Amin, 2015, pp. 185-186).

All other residual powers were entrusted to the provincial governments. Like the Indian Act of 1935, the system of government was Parliamentary and it was compulsory for the Prime Minister and his cabinet ministers to be the members of the National Assembly. Both the Prime Minister and his Cabinet could remain in power as long as they enjoyed the confidence of the assembly and they were also answerable before the National Assembly for their deeds. The President of Pakistan was the head of the state of Pakistan (Kazimi, 2009, p. 261). There was only one chamber of the legislature, the National Assembly, in which the parity principal was ensured for the two provinces of Pakistan by apportioning 150 members for each province for a total 300 members (Sarwar, 2003, pp. 238-241).

\section{Courts under the Constitution of 1956}

The first apex court of independent Pakistan, the Supreme Court, was established in the first Constitution of 1956, a document that also gave the nation its official name, the Islamic Republic of Pakistan. The Constitution created a single federal court system, with no independent, subnational courts for the provinces. This new federal court system was made up of four tiers. At the base of the court system were Civil or Magisterial Courts. The second-tier courts were District Courts. At the third level, were two High Courts for each of the provinces. Finally, the apex court, formerly called the Federal Court, became the Supreme Court, with both original and appellate jurisdiction. The judges of the High Courts and the Supreme Court enjoyed a degree of independence via job tenure guaranteed by the Constitution, and could only be removed prior to retirement through impeachment by the Assembly (Sarwar, 2003, p. 240). 
The Constitution, though parliamentary, deviated from parliamentary norms and gave explicit powers of judicial review to the superior judiciary. Like the United States, Canada, and Australia, the Constitution was made the "supreme law" of the land and the superior courts were given the powers to interpret constitutional law. The superior courts were given powers to issue various writs such as habeas corpus, mandamus, prohibition, quo warranto, and certioraris. The Supreme Court consisted of its chief justice and six other justices (Khan, 2016, pp. 55-57).

\section{The Constitution of 1962}

In 1958, the President of Pakistan, Iskandar Mirza, imposed the nation's first period of martial law by abrogating the first Constitution of Pakistan. He banned all political parties and put the Prime Minister and the members of his Cabinet under house arrest. Later, General Ayub Khan ousted President Mirza, assuming the Presidency for himself.

On February 17, 1960, President Ayub Khan formed a Constitution Commission headed by the former CJ of Pakistan, Justice Shahabbuddin, to present a recommendation for a new constitution of Pakistan (Kazimi, 2009, p. 262). The Constitution Commission presented its recommendations on May 6, 1961. President Khan appointed a Committee to examine the recommendations of the Constitution Committee with Manzoor Qadir, then foreign secretary, as its Chairman. The Cabinet further examined the two reports of the Committee and the final draft of the Constitution was discussed in a Governor's Conference held in the last week of October 1961. On March 1, 1962, General Khan announced the implementation of the new Constitution in a broadcast speech to the nation (Khan, 2016, pp. 193-194). The Constitution of 1962 was the second constitution of the Second Republic of Pakistan.

The Constitution of 1962 was comprised of 250 articles. Pakistan was a federal state under this Constitution, however, there were no separate legislatures for the provinces. While the 
new constitution retained a distribution of powers among the federal and provincial governments, the federal government's share of those powers expanded (Amin, 2015, pp. 196197).

An indirect election method was chosen to select the President, with the elected members of local governments (Basic Democracies Members) given the right to select the nation's highest officer. In the provinces, the president had the right to appoint provincial executives, and the Governors and their ministers were responsible to the president for their duties. The only direct electoral connection in the new system was at the local level where the people had the right to elect their councilors of Basic Democracies, the name for the local government system created by President Khan in the new constitution. There were 40,000 councilors in each of the provinces of West and East Pakistan, for a total of 80,000. These councilors formed an electoral college to select the president and the upper tiers of the Local Governments, including the National Assembly. This constitutional structure was neither parliamentary nor presidential. Rather, the President of Pakistan, who was also the Field Marshal and the Commander of the Armed forces, was the linchpin of the system (Khan, 2016, pp. 167-173).

\section{Courts under the Constitution of 1962}

There was no change in the structures of the courts under this new constitution, however, the powers of the superior courts to interpret the Constitution and laws were reduced. The President of Pakistan had the power to appoint the judges of the superior courts (Kazimi, 2009, p. 262).

Unlike the interim constitutions and the Constitution of 1956, in the Constitution of 1962 the Supreme Court had no power to declare a law unconstitutional on the grounds that the legislature lacked the powers to make a particular law. And the validity of a law passed by the 
legislature could not be called in question in any court of law. Articles 57 and 58 gave powers to Supreme Court to decide the disputes between the central and the provincial governments or between actors within both levels of governments. Individuals and the Court could examine the intent or interpretation of the Constitution after the certification of the High Courts that a case involved an interpretation of the Constitution as well. In 1963, after the first amendment in the Constitution, the Courts vested with powers to decide the vires of the legislature (Khan, 2016, pp. 208-210).

Article 129 of the Constitution gave powers to the CJ of Supreme Court of Pakistan to appoint a special tribunal to resolve a dispute between the Federal and Provincial Governments and disputes among two provinces and the center. The Chief Justice would submit the report to the President of Pakistan for further action (Choudhary, 1959. P. 190).

\section{The Constitution of 1973}

In 1971, the Eastern Province of Pakistan gained its independence and became Bangladesh. 1970 elections in the Western Province of Pakistan led to the selection of new National Assembly, renamed the Constituent Assembly and its first job was to create a new constitution for the former Western Province. The Constitution of 1973 introduced a parliamentary form of government following the British tradition whereby the elected Prime Minister is the real and effective head of the government having all of executive powers and the President is a titular or ceremonial figurehead (Ziring, 1997, p. 395).

Another key feature of the 1973 Constitution is that of federalism. Pakistan now consisted of four provinces and each province has its own elected executive and elected provincial legislature. In the original Constitution of 1973, before amendments, there were lists of powers reserved for the Federal government, for the provinces, and a concurrent list composed 
of the matters where both the Federal government and the provincial governments had the powers to legislate. After the adoption of the Eighteenth Amendment to the Constitution, the third list was repealed with a significant number of the powers transferred to the Provinces, especially in terms of education and local governments (Bengali, 2018, p. 85). However, when federal and provincial law clash, federal law will prevail. There is also a principle of a bicameral legislature: the National Assembly is composed of members elected on the basis of population; and the Senate, where all provinces have an equal share of representatives (Amin, 2015, p. 2015).

\section{Courts under the Constitution of 1973}

The Constitution of 1973 retains the same provisions about the judiciary that were in the previous two constitutions. Article 175, Section 1, of the Constitution of 1973 states "there shall be a Supreme Court of Pakistan, a High Court for each Province and such other courts as may be established by law". Section 2 adds "No court shall have any jurisdiction save as it is or may be conferred on it by the Constitution or by or under any law.” 
Figure 3.1 Judicial Structure of Pakistan's Judiciary

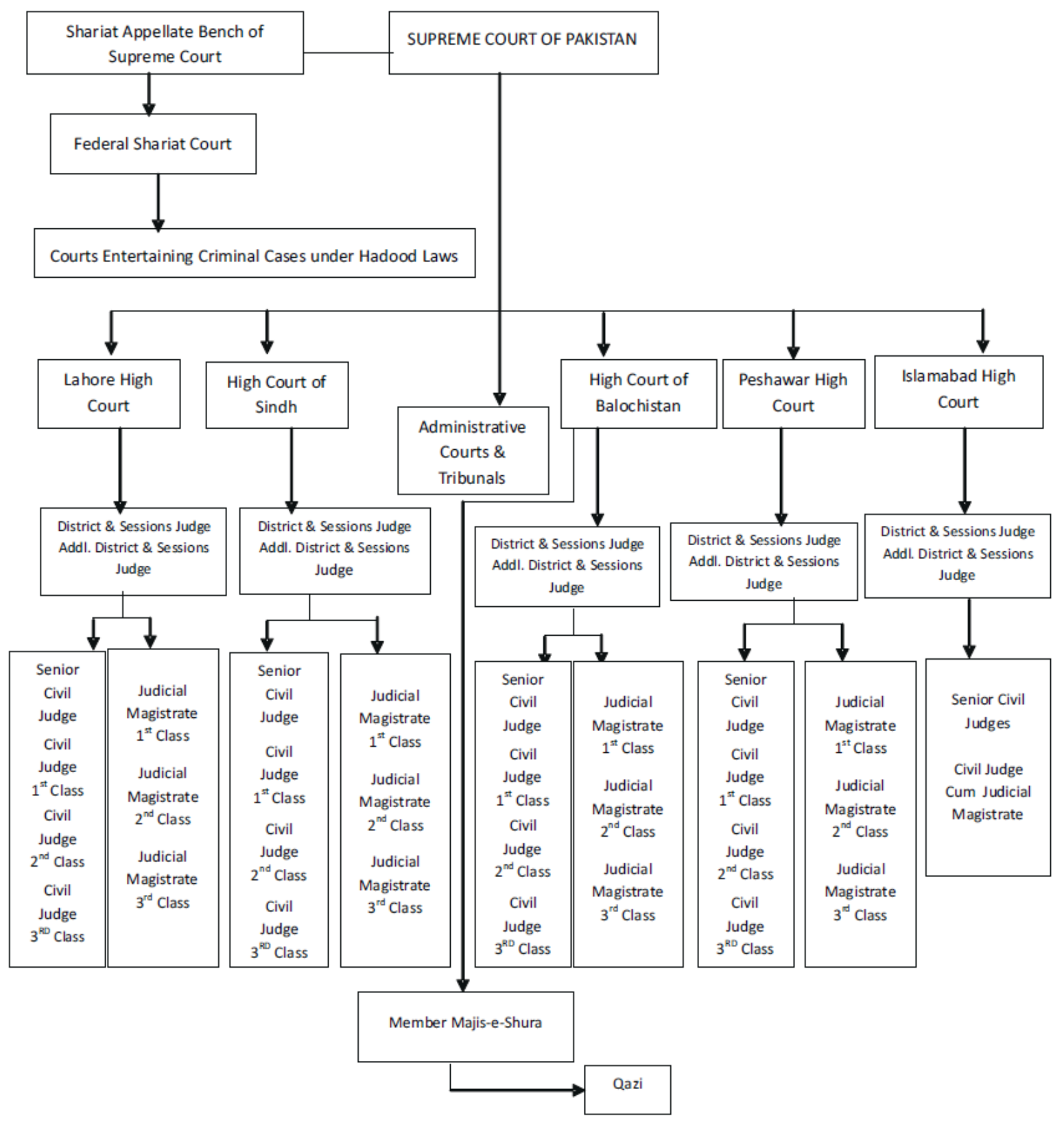

Source: Hussain, (2015). The Judicial System of Pakistan

Figure 3.1 shows the four-tier structure of judiciary in Pakistan under the Constitution of 1973. The Supreme Court of Pakistan is at the apex, five High courts form the second tier, followed by five District courts for each revenue district, with civil/magisterial courts at the lowest level. There is also a Shariat Appelate Bench of Supreme Court judges along with the 
federal Shariat Court to hear cases related to Islamic injunctions, such as cases under the Hadood laws/rape cases. Additional courts such as Accountability Courts, Terrorist Courts, Military Courts, and the Special Courts for Drugs add a layer of complexity to the system. The superior courts have the powers of judicial review; the High Courts and the Supreme Court may declare any law passed by the legislatures, National and Provincial, as null and void. The superior courts can also issue writs of mandamus and declare the actions of the executives, both national and provincial as unconstitutional (Khan, 2009, pp. 385-386).

\section{Courts in Pakistan: The 'Doctrine of Necessity'}

Since its inception in 1947, Pakistan experienced four periods of military rule. The superior courts of the country gave military dictators the power to rule under the umbrella of the "Doctrine of Necessity" or the "Law of Necessity." Both are legal terms designed to give legitimacy or legal cover by the courts to an extra-constitutional regime, usually a government carried out by a military junta. This doctrine is based on the writings and philosophies of two prominent jurists, Henry de Bracton (1208), and William Blackstone (1756) as cited by WolfPhillips (1980). The superior courts in Pakistan mostly relied on an Austrian jurist Hans Kelsen's book on the subject titled "General Theory of Law and State." The application of this doctrine is not common, in particular, no example can be found in the developed or consolidated democracies of the world, including the United Kingdom. However, this principle was applied in developing nations through the Dosso case in Pakistan 1958, the Matouv case in Uganda 1966, the Ndhlovu and Madzimbamuto cases in 1968 in Rhodesia, and the Lakanmi case in 1970 in Nigeria (Wolf-Philips, 1980. P. 37).

The first use of the doctrine came in Pakistan by the Supreme Court when it validated the extra-constitutional emergency powers of the Governor General Mirza Ghulam Muhammad. 
Later military regimes were also legitimized by the Superior judiciary in Pakistan under the same principle. On October 24, 1954, the action by the Governor General Muhammad to dismiss the elected government and dissolve the Constituent Assembly was validated by the Federal Court under the umbrella of the principal of the "Doctrine of Necessarily." In his judgment, the CJ Muhammad Munir quoted the maxim dubbed by Bracton “...that which is otherwise not lawful is made lawful by necessity." In the judicial history of Pakistan, there are a number of landmark cases decided by the superior courts validating extra-legal actions, such as the dismissal of elected governments and dissolutions of the elected assemblies, in the name of restoring order or national security of the State. On the other hand, there have been a handful occasions where the superior courts revisited their judgments and reversed their support of the Doctrine of Necessity. There are some critical court decisions regarding the military interventions that paved the way for the establishment of the 'Principles of Necessity' in the judicial and political history of Pakistan (Wolf-Philips, 1980. pp. 4-6).

\section{The De Facto Role of the Courts in Pakistan}

Hamid Khan (2016) discusses the factors that erode judicial independence of the courts such as the military interventions in the political system of the country and the compromising attitude of the courts under the military regimes. Hoon P. L. (2010) suggests the independence of the courts is subject to efforts by the executive to mold or subvert judges. He suggests the method of appointing judges is often the key to independence. Those appointed through an independent commission made up of lower level judges often ensure the accountability of the judicial branch along with its independence. He criticizes the appointment or selection method of judges in the superior courts of Pakistan where judges or chief justices have a greater say than other people in the society. Neudorf (2017) presents an analysis of the working of the law and 
courts in the United Kingdom in order to compare the legal systems of countries under this case study with each other and with the UK. The chapters related to Pakistan emphasize the historical evolution of the courts in Pakistan and the major crises faced by the judiciary since the inception of the country in 1947. In addition, the author separately discusses the role and performance of the courts in Pakistan under both Military and Civilian eras.

\section{First Civilian Era 1947-1958}

The judiciary in Pakistan started its journey after independence under the leadership of its first Chief Justice Mian Abdul Rashid, previously the CJ of the Lahore High Court. In its early years, the Court heard few politically significant cases. This changed in the Rawalpindi Conspiracy Case of 1951, when serving military officers conspired to topple the civilian government of the first Prime Minister of Pakistan, Liaqat Ali Khan. Rather than let the court decide the case, the government established a special tribunal to investigate the matter. This tribunal was the first example set in the country that the federal government could undermine the powers of the regular or ordinary courts in the country by establishing such special courts and established the first major blow to the independence of the Pakistan judiciary (Khan, 2016, p. 26).

After the retirement of Chief Justice Abdul Rashid in 1954, the appointment of Muhammad Munir as chief justice, bypassing four senior justices at the Federal Court, along with the dissolving of the Constituent Assembly, made it clear the Governor General was attempting to centralize power. Maulvi Tamizuddin, the Speaker of the Assembly, challenged the effort to dissolve the Assembly in a case before the Supreme Court, where it was validated by the newly appointed chief justice and laid the foundation of the Doctrine of Necessity. In the mid1950s, the judiciary again emerged as a controversial institution when it handed down two 
landmark judgments which established that real power was in the hands of the Governor General

Ghulam Muhammad and the Commander in Chief of the Army General Muhammad Auyb Khan, who later imposed the first period of military rule in the country (Khan, 2016, pp. 30-31).

Federation of Pakistan v. Maulvi Tamizuddin Khan, PLD 1955 FC 240

Governor General Ghulam Muhammad dissolved the first Constituent Assembly of Pakistan on October 24, 1954 while the Assembly was busy drafting the first constitution. The proclamation stated:

The Governor General having considered the political crisis with which the country is faced, has with deep regret come to conclusion that the constitutional machinery has broken down. He therefore has decided to declare a state of emergency throughout Pakistan. The Constituent Assembly as at present constituted has lost the confidence of the people and can no longer function. He has called upon the Prime Minister to reform the Cabinet with a view to giving the country a vigorous and stable administration. The invitation has been accepted (Khan, 2009, p. 103).

In actuality, the Constituent Assembly had passed legislation to cripple the powers of the Governor General, which displeased and provoked him. The Assembly introduced the Fifth Amendment Bill in the Government India Act of 1935, then the interim Constitution of Pakistan, in order to constrain the Governor General from dismissing a Government having the confidence of the Assembly. The Fifth Amendment revoked some Sections including 9, 10, 10-A, 10-B and 17 of the Government of the India Act, 1935 through which the powers of the Governor General were stripped away (Khan, 1967, pp. 49-50).

The Speaker of the Constituent Assembly went to the Sind Chief Court against the action of the Governor General and requested the Court to issue the Writ of Mandamus. The Sind Chief Court decided in favor of the petition and declared the proclamation order of the Governor General as null and void. According to the decision, the Constituent Assembly and President Maulvi Tameez-ud-Din were intact and retained power to make law. The Court further declared 
Section 223-A of the Government of the India Act, 1935 which was passed on July 6, 1954, as a valid law that gave the Court the power to issue the writ of mandamus. Section 223-A says:

Every High Court shall have power throughout territories in relation to which it exercises Jurisdiction to issue to any person or authority including in appropriate cases any Government within those territories, writs, including writs in the nature of habeas corpus, mandamus, quo warranto, prohibition and certiorari or any of them.

The Federal Government appealed to the Federal Court of Pakistan (the apex court) against the judgment rendered by the Sind Chief Court in favor of Maulvi Tamizuddin Khan. The Federal Court overruled the judgment of Sind Chief Court and held that Section 223-A would only become law after the signatures of the Governor General under the Indian Independence Act of 1947 (the first interim Constitution of Pakistan) which required the assent of the Governor General to all legislation made by the Constituent Assembly of Pakistan. The full bench of the Federal Court headed by the CJ Muhammad Munir consisted of Justice A.S.M. Akram, Justice A.R. Cornelius, Justice Mohammad Sharif and Justice S.A. Rehman. Justice A.R. Cornelius wrote a dissenting note. The Federal Court of Pakistan held that the Chief Court had no jurisdiction to issue the writ of mandamus under Section 223-A which was yet to be signed by the Governor General to become a law (Federation of Pakistan v. Maulvi Tamizuddin Khan, PLD 1955 FC 240). That said, Justice A.R. Cornelius wrote a dissenting opinion that defined the Constituent Assembly as a superior body that had the power to make or amend laws, as well as write a Constitution without the assent of the governor General (Dawood, 1994, p. 14).

Validation of the dissolution of the first Constituent Assembly by this verdict set a precedent for judicial support of the unconstitutional actions of future military juntas. The judiciary emerged from this episode a weaker institution, which could not become a bulwark against the unconstitutional actions of the military rulers and the civilian presidents who acted on 
behalf of military generals and dismissed elected governments and dissolved the elected legislatures.

\section{Usif Patel v. The Crown, PLD 1955 FC 387}

The Usif Patel case challenged the Sindh Control of Goondas Act, XXVIII of 1952, passed by the Governor of Sindh Province based on an authorization issued by the Governor General of Pakistan (Wolf-Philips, 1980. pp. 5-8). Initially, the District Magistrate of Larkana had declared Usif Patel and two others as the Goondas (Wicked Persons, extortionists) as per the Sind Control of Goondas Act. They filed a case before the Chief Court of Sind in order to declare their detention illegal. They also requested the court for the issuance of the writ of the habeas corpus as per Section 491 of the Criminal procedure Code, 1898. The Chief Court of Sind dismissed their petition and declared their detention legal. The Chief Court Sind also rejected the appellants' appeal to declare the proclamation of the Governor General ultra vires or illegal per Section 92-A of the Government of the India Act by an order/proclamation of the Governor General under Section 9 of the Independence Act. The Constituent Assembly by this Section 9 of the Indian Independence Act had authorized the Governor General of Pakistan to empower the Governor of a province to make laws for that province. Thus, the Governor of Sind had passed the said Act by virtue of such power. The aggrieved party, Usif Patel and others appealed before the Federal Court of Pakistan (Khan, 2016, pp. 43-45).

The major question before the Federal Court was whether the alteration/extension in the adoption date from $31^{\text {st }}$ March 1948 to $31^{\text {st }}$ March 1949 by the Constituent Assembly without the assent of the Governor General was legal. The Federal Court had already decided in the Federation of Pakistan v. Maulvi Tameez-ud-Din case that the law passed by the Constituent Assembly without the assent of the Governor General was unconstitutional. The Federal Court in 
the Usif Patel case also upheld the previous reasoning that no law could be passed without the assent of the Governor General. The Federal Court of Pakistan upheld the appeal of appellants and the detainees were freed (Khan, 2016, pp. 43-45).

The Federal Court also recommended that in these circumstances the Government should work to establish a new representative body or legislature in order to make valid laws. According to the Federal Court, neither the Governor General alone through Emergency Powers Act or through an Ordinance nor the Constituent Assembly alone could make laws, but that the representative body, i.e., the legislature, with the assent of the Governor General could (WolfPhilips, 1980. pp. 6-8). This ruling established the supremacy of Federal Court over both the Governor General and the elected legislature and it ordered the Government to work on the calling of a new elected representative assembly to make the new Constitution of the country.

\section{Courts under the First Military Regime: Ayub Khan Era 1958-1969}

On October 7, 1958, the President of Pakistan, Iskandar Mirza, imposed the first nationwide period of martial law in Pakistan. The president in his proclamation abrogated the first Constitution of 1956 . He dismissed the central and provincial governments. He also dissolved the National Assembly and the provincial Assemblies of East and West Pakistan (Long, 2015, p. 489). General Muhammad Ayub Khan, the Commander-in-Chief of the Armed Forces, was made the Chief Martial Law Administrator (CMLA) and later Prime Minister, a move that eventually led to a power struggle between the President and the new PM. Finally, on October 27, 1958 General Khan ousted President Mirza and declared himself the President of Pakistan, exiling Mirza to the United Kingdom (Khan, 2016, pp 62-65). 


\section{State v. Dosso, PLD 1958 SC 533}

The Council of Elders convicted appellants Dosso and others under Section 11 of the Federal Crimes Regulation, Act III of 1901. Dosso case is also another example of a hindrance in the independence of judiciary in the judicial history of Pakistan. The appellants filed constitutional petitions under Section 170 of the Constitution of 1956 at the West Pakistan High Court. The West Pakistan High Court declared Federal Crimes Regulation, Act III of 1901 contradictory to the fundamental rights as guaranteed by the Article 5 of the Constitution of 1956 and gave relief to Dosso and the others. These orders of the High Court were then challenged in the Supreme Court of Pakistan. The Supreme Court reversed the decision of the High Court on the same analogy applied in previous two cases, the Tamezuddin and Patel cases, upholding once again the Doctrine of Necessity (Wolf-Philips, 1980. pp. 11-14).

CJ Muhammad Munir wrote in his decision that after the successful coup d'état, which the Court called a "revolution," Article 5 of the Constitution of 1956 had already disappeared from the new legal order, however, the Court held that the Federal Crimes Regulation Order of 1901 was still a valid law by virtue of the Continuance in Force Order 1958 issued by the new regime. According to Justice Munir, a successful "revolution" could validly change the Constitution. He further stated that a successful revolution passes the test of its efficacy and the order of the successful regime becomes the valid and the basic law of the land. The Supreme Court of Pakistan headed by CJ Munir upheld once again the 'Doctrine of Necessity' first established in Maulvi Tameezuddin Case in 1954 (Wolf-Philips, 1980. pp. 12-13).

\section{Courts under the Second Military Regime: Yahya Khan Era 1969-1971}

In late 1960s, there were mass protests against the military regime of General Ayub Khan. All opposition parties, after the failed negotiations with the Ayub administration, started a 
political movement to topple the government. On March 25, 1969, General Ayub Khan provided this opportunity himself when he transferred his reins of powers to the Army Chief General Yahya Khan. Yahya Khan took the control of the Government of Pakistan as the second martial law administrator and later assumed the office of the President of Pakistan (Khan, 2009, pp. 274283).

Yahya Khan abrogated the Constitution of 1962 and declared martial law in the country. He issued an interim constitutional order, the Legal Framework Order (LFO), to run the affairs of State. He organized the general elections in which the Awami League of East Pakistan, led by Sheikh Mujibur Rehman, won 160 out of the total 300 seats in the National Assembly. Zulfikar Ali Bhutto's Pakistan People's Party (PPP) secured the second position with 81 seats in the legislature. Both political leaders failed to compromise on any political solution and Yahya Khan decided against handing over power to Shiekh Mujibur Rehman. There were protests on a large scale in the eastern Bengal province of the country and Yahya Khan launched military action against the supporters of the Awami League. India took advantage of the opportunity to intervene in East Pakistan and the third War between India and Pakistan started. On December 16, 1971, the Pakistan Army had to surrender and Shiekh Mujibur Rehman declared the independence of the East Bengal and Bangladesh emerged as an independent country (Neudorf, 2017, p. 161). Under General Yaha Khan's rule in 1970, there was no Constitution in the country but an interim arrangement called the Legal Framework Order (LFO) issued by him to govern. Thus, the courts became subservient to the military ruler and failed to perform their role freely or independently. 


\section{Asma Jilani v. Government of the Punjab, PLD 1972 SC 139}

On December 22, 1971, the government arrested Malik Ghulam Jilani, Altaf Gauhar and others for political reasons in order to punish the opposition. Asma Jilani, daughter of Jilani, and Zarina Gauhar, wife of Gauhar, challenged these arrests in the Lahore High Court through a writ petition. The Court admitted the petition and notices were issued to the Government of the Punjab. On December 29, 1971, a day before their appearance in the Court, the Government rescinded the previous order of arrest and substituted another issued under Martial Law. The Government raised the initial objection that the Lahore High Court had no jurisdiction by virtue of the provisions of clause 2 of the Jurisdiction of Courts (Removal of Doubts) Order, 1969 promulgated by the CMLA. The Lahore High Court accepted the plea relying on the State v. Dosso PLD 1958 SC 533 and held that the Jurisdiction of Courts Order was valid and binding. Thus, the Court had no jurisdiction to entertain and decide the petition (Khan, 2016, pp. 143144).

The petitioners appealed in the Supreme Court. The Supreme Court set aside the Doctrine of Necessity and declared both orders of detention void and illegal and set the detainees free. The Supreme Court ruled that "this country was not a foreign country invaded by an army headed by General Yahya Khan, nor was it an alien territory which had been conquered by said army." Therefore, martial law was never superior to the Constitution. The Supreme Court further held that General Yahya Khan was neither a victor nor was Pakistan occupied territory. The Court also declared him a "usurper" and held his actions illegal (Wolf-Philips, 1980, 17-20).

The interesting fact about this case is that when the judgment was released Yahya Khan was not in power. Zulfikar Ali Bhutto's political party the Pakistan People's Party was in power in the Western part of the country after the separation of East Pakistan from the mainland due to 
the insurgency and war with India in 1971. After this war, Bhutto assumed the office of first civilian Martial Law Administrator and later became President and then Prime Minister of Pakistan. Still, the Court's decision was an effort to reestablish judicial independence and rein in the military government.

\section{Courts under Second Civilian Rule: Zulfikar Ali Bhutto Era 1971-1977}

Under the civilian administration of Prime Minister Ali Bhutto, Pakistan adopted its third constitution. Article 232 of the Constitution guaranteed the fundamental right of the people and set up the courts as the guarantor of those rights. The civil administration framed the Defense of Pakistan Rules, which declared an emergency in the country and curtailed the powers of the ordinary courts. Special courts and tribunals were established for the trial of political opponents, bypassing the courts and their powers to grant relief to those charged (Marri, 1990, pp. 54-55).

The civilian regime introduced the Fourth Amendment to the Constitution, intent on curtailing the power of the High Courts. The courts were denied the power to grant bail to the detained, to issue stays of recovery or to offer assessment and the collection of public revenues were also removed. The Sixth Amendment to the Constitution was designed to force the retirement of those judges of the superior courts who were not supportive of the Bhutto regime by introducing an upper-age limit for the Chief Justices of the Supreme Court and High Courts. Article 204 of the Constitution relating to the judiciary's powers to punish contempt of court cases was also curtailed. After this amendment, the judges of the High Courts could be transferred without their consent or the consent of the Chief Justices of the affected courts. As an immediate consequence, the chief justices of the two High Courts, the Lahore High Court and the Peshawar High Court, were forced to resign due to the change in the retirement age (Khan, 2016, pp. 164-166). 


\section{Begum Nusrat Bhutto v. Chief of the Army Staff, PLD 1977 SC 657}

In 1977, Prime Minister Ali Bhutto announced early general elections hoping that his PPP would win the majority of the electorate. General elections were held on March 7, 1977 and the Pakistan People's Party, the ruling party won the majority in the National Assembly by getting 155 seats out of total 200 seats. The opposition party, the Pakistan National Alliance (PNA) secured only 36 seats. The opposition parties refused to accept the election results and called the elections flawed and rigged (Marri, 1990, pp. 53-54).

The opposition parties not only refused to accept the results of this election, but launched a mass movement against the Bhutto regime. People came out in large numbers and made it difficult for the security agencies and the police to control the situation in the country. The civil government of the PPP called the military in to assist the civilian institutions in order to restore peace in the country. The government arrested the major leaders of the opposition parties and launched a massive crackdown on the opposition but failed to curb the protest. Many people died in clashes with law enforcement and the military. Finally, the military refused to obey the orders of the civilian rulers and military chief General Zia-Ul-Haq imposed martial law in the country and took over control of all civilian institutions. He deposed Prime Minister Ali Bhutto and put him under house arrest at Adyala. Chief Martial Administrator (CMLA) General Zia then dissolved the National Assembly of Pakistan and all Provincial Assemblies as well. The Governors of the provinces dismissed the provincial heads of governments. General Zia in his speech to the nation mentioned the reasons for his takeover and promised to hand over control of the country within three months of fair and free elections. General Zia-Ul-Haq did not abrogate the Constitution of 1973, but on the advice of A.K. Brohi held the Constitution in abeyance (Khan, 2009, pp. 437-438). 
Begum Nusrat Bhutto, wife of deposed Prime Minister Zulfikar Ali Bhutto filed a petition in the Supreme Court of Pakistan under Article 184 (3) of the Constitution of 1973 challenging the Martial Law Order N0.12, 1977 contending that the Chief of Army Staff had no legal authority to impose martial Law, promulgate the Laws (Continuance in Force) Order, and Martial Law Order of July 5, 1977, and the illegal detention of PPP leaders including her husband. Her appeal argued that this intervention by the Army Chief amounted to high treason as stipulated in the Article 6 of the Constitution of 1973 (Wolf-Phillips, 1980, p.22).

Mr. Yahya Bakhtiar, counsel for the PPP, pleaded the case by relying heavily on Asma Jillani's case. He contended that the Army Chief had no lawful authority to depose the elected Prime Minister and the elected Assemblies in the country. He pleaded that the act of the Army Chief was illegal and required the Superior Judiciary to redress the case under the Article 184 (3) giving the powers to the Court to enforce fundamental rights after ensuring that issues of public importance was involved (Wolf-Phillips, 1980, p.23).

On the other hand, Mr. A.K. Brohi, counsel for the Federation of Pakistan, argued that before the imposition of martial law, the country was run by the Constitution of 1973, which was held in abeyance, and the new military regime enforced a new legal order which got its validity from the proclamations of the CMLA and the Continuance in Force Order. This change was not through the suspended constitution, but it constituted a meta-legal or extra-constitutional fact based on the doctrine of "revolutionary legality." Now courts were working under the new legal order issued by the new military regime after a successful revolution or coup d'état (Zafar, 2019, p. 268).

The Attorney General of Pakistan, Mr. Sharif-ud-Din Peerzada, appeared before the court as a Law Officer and he supported the argument that martial law did not amount to a usurpation 
of power by the Chief of Army Staff. According to him, the military intended to oust the Prime Minister because he was a usurper who had illegally occupied the office again as a result of massive rigging in the 1977 elections (Khan, 2016, pp185-186).

The Supreme Court established the principle that a successful revolution satisfies itself the test of efficacy and becomes a basic law. On November 10, 1977, the Supreme Court of Pakistan decided unanimously (9 Judges heard the case) that the extra-constitutional step taken by the Army Chief was justified by the requirements of "state necessity" and the "welfare of the people." Therefore, according to the Court, the ousting of Prime Minister Zulfikar Ali Bhutto from office was valid and lawful. The appeal to release Bhutto and other PPP leaders was also dismissed as incompetent (Wolf-Phillips, 1980, pp. 27-28).

\section{Eighth Amendment, Article 58 (2) (B)}

General Muhammad Zia U1 Haq promised to hold elections within ninety days of the coup d'état and he also argued to the courts that the major purpose behind the coup was to hold free and fair elections in the country in order to hand over the government over to democratically elected representatives of the people. In fact, he did not fulfill his promise to the nation to hold elections within 90 days and prolonged his rule indefinitely. The opposition parties under the umbrella of the Movement for the Restoration of Democracy (MRD) launched a mass movement against the military regime. Though the MRD movement was not successful, it did build pressure on the military junta to hold elections in the country as they had promised to the nation.

For the first time in the political history of Pakistan, non-party elections were held in 1985. There were two major factions in the Assembly, one of them became a political party named the Pakistan Muslim League with the support of the President General Zia U1 Haq, who was still in military uniform. There was also a sizeable alliance of opposition parties in the 
National Assembly. The ruling party of Prime Minister Muhammad Khan Jonejo, handpicked Prime Minister of General Zia and the opposition parties agreed to amend the Constitution through the Eighth Amendment which gave powers to the president under Article 58 (2) (b) to dismiss the elected government along with the powers to dissolve the National Assembly. In return, the President of Pakistan who was still the Army Chief of the Armed Forces agreed to resign as the Army Chief, but vowed to remain as a civilian President of Pakistan. Because of this deal between the ruling party and the opposition, the president had acquired the powers to dismiss the government and dissolve the legislative body.

A voluminous literature deals with court cases of superior courts in Pakistan where the courts upheld the actions of the military rulers, in particular, after the adoption of the Eight Amendment. The political and judicial history of Pakistan revolved around those landmark cases where presidents dismissed elected prime ministers and dissolved elected assemblies and the superior courts had to decide whether or not the President used constitutional power fairly and properly under the law. After the cases involving the principle of the Doctrine of Necessity, the courts had to compromise with presidents having the support of the military establishment. These two major political and judicial issues were the hallmarks of judicial independence in the country other than the Public Interest Litigation (PIL) through suo moto powers of the Superior Judiciary or later the Contempt of court cases after the Lawyers' Movement (Khan, 2016; Kalhan, 2013; Jaffrelot, 2015; Long, 2015; Maluka, 1995; Newberg, 1995; Shah, 2014; Zafar, 2019).

As far as the suo moto powers of the Supreme Court are concerned, Article 184 (3) of the Constitution of Pakistan entrust powers to the Supreme Court of Pakistan in order to protect the fundamental rights of the people of Pakistan. It is stated in this Article:

Without prejudice to the provisions of Article 199, the Supreme Court shall, if it considers that a question of public importance with reference to the enforcement of any 
of the Fundamental Rights conferred by Chapter I of Part II is involved, have the power to make an order of the nature mentioned in the said article.

\section{Muhammad Saifullah Khan v. Federation of Pakistan, PLD 1990 SC 79}

In May 1988, General Zia U1 Haq, issued proclamation orders dismissing the Prime Minister, his cabinet, dissolving the National Assembly, and all provincial governments and assemblies. These orders were challenged in the Lahore High Court and later appealed in the Supreme Court. The full bench of the Lahore High Court declared the orders unsustainable, however, it refused to restore the governments and assemblies due to the announcement of fresh elections in the country.

The decision of the Lahore High Court was challenged in the Supreme Court in the case Federation of Pakistan v. Haji Muhammad Saifullah Khan. The Supreme Court held that the discretionary powers of the President after the $8^{\text {th }}$ Amendment under Article 58 (2) (b) were not absolute and were subject to the circumstances or conditions mentioned in the Constitution. The Supreme Court held that it had the jurisdiction to declare such orders of the President unconstitutional if they were not exercised in consonance with the purpose of the law that conferred these powers. Thus, the Supreme Court declared the dissolution of the National Assembly by General Zia ul Haq as invalid and illegal.

The Supreme Court upheld the decision of the Lahore High Court that the action of the President was unconstitutional. However, the Supreme Court denied the relief of restoring the deposed regime along with dissolved assemblies due to the reason that the general elections had already been announced and the nation was ready to vote for a new government and assemblies. While a seeming exercise in judicial independence, the decision came a year after the dictator's death and proved the court was not above taking advantage of such events to reclaim its authority (Khan, 2016, pp, 249-251). 


\section{Benazir Bhutto and Nawaz Sharif Eras 1988-1999}

There were four general elections in Pakistan from November 1988 to October 1999. The Pakistan Peoples' Party (PPP) of Benazir Bhutto won in November 1988, and again in October 1993. The Pakistan Muslim League (N) won the general elections of October 1990 and of February 1997. The two civilian regimes of Benazir Bhutto and Nawaz Sharif were marked by two major issues, first, the feud between the Prime Ministers and the head of State, i.e., the President. Second was the tussle between the executive and the judiciary, to be more precise between the Prime Minister and the CJ of the Supreme Court of Pakistan over the appointment of the justices in the Superior Courts. Similarly, another tug of war occurred between the ruling party and the opposition. There were conflicts between the Prime Ministers and the Presidents, and sometimes with the Chief Justice of the Supreme Court over political and legal issues. The military establishment had to side either with the government, i.e., the Prime Minister or the President or the CJ. Both Ms. Benazir Bhutto and Nawaz Sharif as Prime Ministers developed tensions with their Presidents and the CJ of the Supreme Court, who was then Syed Sajjad Ali Shah. During Nawaz Sharif period, in one incident, the CJ of Pakistan had to leave his chair along with other justices due to a mob assault on the Supreme Court building. Both Prime Ministers developed conflicts with the CJ on the appointment of the justices of the Superior Judiciary. According to the CJ Sajjad Ali Shah, both Prime Ministers insisted on the appointment of their favorites as judges at the High Courts and the Supreme Court. Before $18^{\text {th }}$ Amendment to the Constitution, the appointment of the justices of the Superior Judiciary was the prerogative of the executive with the consultation of their respective Chief Justices.

The major reason of the tension between prime ministers and presidents was over Article 58 (2) (b), the President's constitutional right to dismiss the Prime Minister and to dissolve the elected Assemblies. Article 58 (2) (b) was considered as a safety valve to avoid direct a military 
coup, allowing the military establishment, with the support of the president, to get rid of the civilian governments. During their tenures each president used this right, forcing superior courts to decide the cases either in favor of the deposed prime ministers and their governments or the presidents who acted with the ostensible support of the military establishment. These cases are the examples of the pressures on the superior courts, even during the civilian regimes (see Khan, 2009, 2016; Long, 2015; Samdani, 2004; Talbot, 2009; Waseem, 2012; Zafar, 2019).

\section{Ahmad Tariq Rahim v. Federation of Pakistan, PLD 1991 SC 78}

On August 6, 1990, President Ghulam Ishaq Khan dismissed the first government of Prime Minister Benazir Bhutto and dissolved the National Assembly. The $8^{\text {th }}$ Amendment of the Constitution of 1973 empowered the president with the powers of dismissal of federal government along with the federal legislature, the National Assembly, if he considered that the functioning of the governments cannot be carried out in accordance with the Constitution. The President stated the reasons of the dismissal of the government and the dissolution of the

National Assembly in his Proclamation Orders as follows:

The President having considered the situation in the country, the events that have taken place and the circumstance, and among others for the reasons mentioned below is of the opinion that government of the federation cannot be carried on in accordance with the provisions of the Constitution, and an appeal to the electorate is necessary...therefore I, Ghulam Ishaq Khan, President of Islamic Republic of Pakistan in exercise of the powers conferred on me by clause (2) (b) of Article 58 of the Constitution of 1973 of the Islamic Republic of Pakistan dissolve the National Assembly with immediate effect; and the Prime Minister and the Cabinet shall cease to hold office forthwith.

The orders of the dissolution of the National Assembly and the dismissal of the Prime

Minster were challenged in two High Courts, the Lahore High Court, and the Sindh High Court.

Both High Courts upheld the orders of dismissal. The decision of the Lahore High Court was appealed in the Supreme Court, which found that despite the fact that the President of Pakistan warned the federal government that the disputes between the federal government and the 
provinces were immense in nature and could threaten the very existence of country as a federation if not resolved properly, the federal government failed to act. The Court observed that despite the intercession of the head of state, the constitutional obligations were not discharged and the actions of the president were constitutional. The decision was a clear indication that the superior courts were making compromises on their independence (Khan, 2009, pp 255-257).

\section{Muhammad Nawaz Sharif v. Federation of Pakistan, PLD 1993 SC 473}

There was little surprise when the Prime Minister Nawaz Sharif attempted to amend the powers of the president to dismiss prime ministers and dissolve Parliaments in 1993. President Ishaq Khan called such powers a safety valve between the military takeover and democracy, while Sharif, in a televised speech to the nation, called for their repeal and refused to take direction from the president or from any other source. The day following this speech, President Khan dismissed Prime Minister Nawaz Sharif and his cabinet and dissolved the National Assembly.

The Speaker of National Assembly, Gohar Ayub Khan, challenged the dissolution orders in Lahore High Court. The next day, deposed Prime Minister Nawaz Sharif appealed directly to the Supreme Court under Article 184(3) of the Constitution, suggesting the presidential actions violated the fundamental rights of the people to select their government. For the first time in the judicial and political history of Pakistan, the Supreme Court restored the deposed Prime Minster, the Cabinet and the National Assembly. However, this historic decision was short-lived as the Prime Minister was forced to resign and dissolve the National Assembly when General Waheed Kakar, the Army Chief of Staff, forced both the President and Prime Minister to resign, with the proviso that General Kakar himself would not seek reappointment as the Army Chief of Staff (Khan, 2016, pp. 299-300). 


\section{Benazir Bhutto v. President of Pakistan, PLD 1992 SC 59}

After the resignation of Sharif, the regime of the Pakistan Muslim League came to an end and the caretaker government announced plans for elections in three months. After the elections in 1993, Benazir Bhutto came into power and her PPP won the majority with 86 seats in the National Assembly. Benazir Bhutto, with the help of her allies, became the Prime Minister of Pakistan for the second time in history and her party came into power for the fourth time. The differences between the President and Prime Minister quickly resumed. The President of Pakistan, Farooq Ahmad Khan Leghari, while a stalwart of the Pakistan People's Party and a close friend of Prime Minister Bhutto, had differences with her on many issues, including the appointment of judges to the superior judiciary. The Prime Minster was also in conflict with the CJ of Pakistan over the appointment of judges to the High Courts and the Supreme Court. Both the President and CJ Sajjad Ali Shah joined hands in support of the military establishment and decided to get rid of the Bhutto regime.

President Farooq Leghari dismissed Prime Minister Bhutto and her Cabinet and dissolved of the National Assembly on November 5, 1996. He appointed a former Speaker of the National Assembly as caretaker Prime Minister of Pakistan. President Farooq Leghari explained his actions this way:

Whereas during the last three years, thousands of persons in Karachi and other parts of Pakistan have been deprived of their right to life in violation of Article 9 of the Constitution. They have been killed in police encounters and in police custody. In the speech to the Parliament on 29 October, 1995, the President warned that the law enforcement agencies must ensure that there is no harassment of innocent citizens in the fight against terrorism and that human and legal rights of all persons are dully protected. This advice was not heeded. The killings continued unabated.

Apart from the extra-judicial killings, the President framed a charge sheet against the regime which including widespread corruption and undermining the independence of the 
judiciary by violating the Article 2 A and 190 of the Constitution of 1973. The former Speaker of the Assembly filed a writ petition in the Supreme Court, as did the Prime Minister. The Supreme Court rejected both appeals (6-1) and upheld the orders of the President as constitutional (Khan, 2009, pp. 613-615). In the case of the Bhutto regime, it appeared the court had learned to settle for quasi-independence, allying itself with the President and the military.

\section{Courts Under the Fourth Military Regime: General Pervez Musharraf Era 1999-2006}

The Army Chief General Pervez Musharraf imposed Martial Law in the country on October 12, 1999. Prime Minister Nawaz Sharif was arrested, and the National Assembly and all four Provincial legislatures were dissolved. The Army Chief installed himself as the Chief Executive, Chairman of the Joint Chiefs of Staff, and later as the President of the country by issuing the Provisional Constitutional Order (PCO) and suspending the Constitution of 1973. There were already differences between Musharraf and Prime Minister Nawaz Sharif over Pakistan's military adventure with India in the Kargil War. The manner of removal of the Army Chief by Sharif, while he was in plane returning from his official visit with Sri Lanka, further escalated the feud between them. The military top brass considered the removal of their Chief as an insult and refused to accept the new Army Chief, General Ziauddin Butt, then Director General of the ISI. The Commanders of the armed forces decided to defend their chief and launched a coup d'état against the Sharif regime (Amin, 2015; Kazimi, 2009; Khan, 2009; Long, 2015; Musharraf, 2006; Waseem, 2012; Zafar, 2019).

\section{Zafar Ali Shah v. General Pervez, Musharraf, PLD 2000 SC 869}

Deposed Prime Minister Nawaz Sharif and his other party leaders challenged the actions of the Army Chief and his Proclamation of Emergency Order of October 14, 1999, and PCO No. 1 of 1999 in the Supreme Court. The petitioners argued the Army Chief had no lawful powers to 
dismiss the government or the elected assemblies. The twelve-member bench, headed by CJ Irshad Hassan Khan, rejected the petition and upheld the doctrine of state necessity. They argued in their opinion that the Army Chief had the power to amend the Constitution as he deemed fit, thereby giving him powers that even the Supreme Court did not possess (Khan, 2016, pp 421423). Acting under the powers given to him by the Supreme Court, Musharraf sought a new oath of office from the judges of the Superior Courts. Most of the judges took the oath on the PCO and retained their positions in the judiciary. In the Zafar Ali Shah case, the Supreme Court had also granted three years to Musharraf to hold new elections and for the restoration of the Constitution and, in turn, Musharraf gave three-year extensions of service to the incumbent judges.

\section{Conclusion}

Since the independence of Pakistan in 1947, the judiciary has played an inconsistent role in the political development of the country. It earned an image as a stooge of the ruling regime, particularly under military juntas. Through their decisions, the courts gave legitimacy and validation to the military rulers when they abrogated and suspended the Constitution, preserving the laws that safeguarded these leaders' political control and undercut their own authority. These courts also helped the military to curb the powers of elected officials and political parties. As a result, the courts lost the respect of the general public and the legal community itself, further eroding important bases of judicial independence. Pakistan has experienced four military governments in her political history since gaining independence. The military has amended the Constitution to prolong their rule and to curb political freedoms. One amendment has paramount importance for the political and judicial history of Pakistan. Article 58 (2) (b) gave the President of Pakistan powers to dismiss the Prime Minster and his Cabinet and to dissolve the National 
Assembly of Pakistan. This provision gave the military, even when it was not in direct control, the ability to intervene and interfere with the affairs of the executive branch, often with the collaboration of the judiciary. After the adoption of the $8^{\text {th }}$ Amendment in the Constitution, different Presidents dismissed four civilian rulers and elected Assemblies. The superior courts sanctioned the legitimacy and validity to these actions of the presidents, and as result, the courts themselves were weakened. The judges were parties to the diminishment of their own judicial independence.

Military takeovers are not the only cause of the failure of the judiciary to realize the independence seemingly granted it in the Constitution. Constitutional amendments like the Fourth, Fifth, and Sixth Amendments introduced by former Prime Minister Zulfikar Ali Bhutto, also worked to reduce the powers of the judiciary. Both military and civilian leaders played a similar role in undermining the institution of the judiciary. In addition to the military and politicians, a former Justice of the Lahore High Court candidly blamed the judges themselves for the deterioration of judicial independence. According to him, judges take an oath to defend the Constitution but too often violate that promise when they make compromises with rulers to protect their perks and positions, becoming victims of fear and favor.

In most cases, the courts in Pakistan played the upstream role of the agent of military rulers and their anti-democratic actions through their verdicts supporting coups. There was very little evidence the second role, that of courts as downstream guarantors where they preferred democratic norms over the justice or truth in order to strengthens democracy through the burial of the past dictatorial actions. Similarly, the courts' role in the consolidation of democracy by supporting the transitional democratic regimes has also been insignificant in Pakistan. The superior courts did not support democratic forces when these forces won the battle against the 
military rulers. The civilian democratic regimes faced difficulties caused by the courts because the judiciary was closely aligned with the military. The major roles of courts in Pakistan have been to provide maximum support to the old guard as an agent of the past and less support to the democratic forces that challenged the status quo.

There has been a consistency in the legal system of Pakistan, from the palace Court of Rajas and Maha Rajas through the arrival of the Muslim rulers, India (and by extension Pakistan) had a judicial structure comprising both individuals and institutions. The modern judicial system introduced by the British simply added additional layers to this pre-existing system, along with the adoption of a parliamentary form of government, which introduced yet another institutional basis of power. Pakistan inherited its legal tradition from the United Kingdom, but with some major differences, such as a written constitution. Unlike, the British parliamentary supremacy principle, where the courts could not strike down an Act of the Parliament, the courts in Pakistan—at least in theory—were granted the power of judicial review.

As far as the de jure independence of the courts is concerned, the judiciary was fully authorized by constitutional provisions to exercise their right to judicial review and intervene to stop the excesses of the executive and legislative branches of the government. The courts enjoyed full textual or legal support from the written constitution. However, as far de facto independence is concerned, there have been a constant set of challenges as mentioned above that regularly challenged the independence of the courts and their role in Pakistan.

As far as the status of judicial independence before the Lawyers' Movement goes, it was infrequent and regularly eroded via military interventions. During most of their history, the Pakistan courts upheld "state necessity" and supported military interventions in the political system. When the courts had to choose between democratic freedom and state solidarity, they sided with state solidarity over democracy and judicial independence. As I discuss in the next 
two chapters, the courts changed their posture as a result of the historic Lawyers' Movement of 2007-2009. 


\section{Chapter 5}

\section{The Lawyers' Movement: Origins and Development}

\section{Introduction}

This chapter presents a case study of a social movement in Pakistan that sought to restore independence to the nation's courts and restore deposed judges, but this movement unleashed far more, it toppled a military dictator and fundamentally transformed the Pakistani polity. Relying on my interview data and other sources, I introduce the reader to the Lawyers' Movement (LM) and show how it grew from a spontaneous resistance to the military regime's assault on the independence of the courts of Pakistan to a nationwide movement that sought to topple the dictatorship, establish the rule of law and respect for individual rights, and ultimately restore democracy. My case study of the Lawyers' Movement builds on and adds to the literature on the impact of social movements and cause lawyering. Large parts of the Pakistani legal community and bench risked their professional careers to take a firm stand for the principles of judicial independence and the rule of law. Despite the fact that many lawyers' incomes were wholly dependent on their daily appearances before the courts, they boycotted them. They continued their struggle for over two years without any means of income, taking their fight to the streets, while facing brutal treatment by the police, all to restore the lost respect of the courts. This type of wide-scale professional resistance was and is unprecedented in the world. The legal community in Pakistan, with the support of a vibrant civil society, fought valiantly and succeeded in restoring the basic human legal rights in the form of a free judiciary and the rule of law.

This chapter examines the evolution of the LM, arguing it was an outgrowth of public resentment towards the military junta and its use of police brutality to maintain power. This 
chapter also highlights the role of the modern media, political parties, groups in civil society such as students, teachers, doctors, engineers, and the pressure brought by other governments and non-governmental institutions that contributed to the success of the Lawyers' Movement.

This chapter will focus on the legal, constitutional, political, and social background of the members of the LM, arguing that their political entrepreneurship led to the mobilization of the legal profession in resistance to the military junta. As such, it poses and answers several questions: What were the major goals of the participants? How were they able to mobilize the material and finances for this movement? How did they make strategic and tactical decisions? What have they achieved? In this chapter, I examine how the leadership viewed or perceived judicial independence and whether they thought they were capable of transforming the nation's courts.

\section{The Lawyers' Movement: A Prelude}

Pakistan's fourth military leader, General Pervez Musharraf, wore four caps at once: Chief of the Army Staff, Chairman of the Joint Chiefs of Staff, Chief Executive, and President of Pakistan. As the latter, he created his own political party (the Pakistan Muslim League (Q), made up of handpicked politicians which ruled the country without any resistance from the opposition. However, March 9, 2007 proved to be turning point, or a focusing event, in the political and judicial history of Pakistan. Scheduled in late 2007, a case was pending in the Supreme Court regarding the constitutional propriety of President Musharraf's election for his second term as a president in uniform. There was speculation that the Supreme Court might disqualify him for the ballot. In response, Musharraf suspended Chief Justice Iftikhar Mohammad Chaudhary along with 64 other judges of the Supreme Court and High Courts. In addition, on the orders of General Musharraf, the removed justices and judges, along with their families, were placed under 
house arrest (Ahmed, 2012; Ahmed \& Stephan, 2010; Amin, 2015; Anwar, 2009; Faqir, et al., 2013).

In response, and under the leadership of the deposed CJ Chaudhary, bar associations, lawyers, and civil society groups launched a unique and unprecedented movement against the military regime. This movement started with large public protests and marches, boycotts of the courts, and massive rallies all over the country; collectively, these actions became known as the Lawyers' Movement (LM). The LM continued for twenty-four months, eventually forcing General Musharraf to resign. The new civilian government that replaced him restored the deposed judges, including CJ Chaudhary, to the bench. The LM awakened, mobilized, and unified the people of Pakistan to demand an independent and free judiciary (Harvard Law School Report, 2010; Human Rights Watch, 2007; Kareem, 2009; Malik, 2008; Sheikh, 2009).

The LM was multi-dimensional. It was a protest against the oppressive military regime of General Musharraf. It was also a sign of growing political awareness among the people regarding the political rights of the citizens in a democracy. As it matured, the LM turned into a social movement, mobilizing the public to pursue their rights, in particular, their legal, political, and constitutional rights. In addition, the movement, its leaders, and participants worked to establish a free judiciary, the rule of law, and democracy in Pakistan (Ghias, 2010; Hassan, 2009; Kareem, 2009; Human Rights Watch, 2007).

In this case study, I will discuss the origins of the movement, its progenitors, leadership, political entrepreneurship, the activities of the movement, and the mobilization of lawyers and their professional organizations in support of the LM. In addition, I will examine to what degree the leadership of this movement focused on judicial independence (JI) and why they thought that their movement could change the judicial environment to the one that is conducive to an 
independent judiciary and the rule of law. Finally, I will analyze how successful the LM was in bringing about these changes.

\section{The Road to the Lawyers' Movement}

Ghias (2010) describes the development of the LM from June 30, 2005 forward when Justice Iftikhar Mohammad Chaudhary became the Chief Justice of the Supreme Court of Pakistan. Chaudhary initiated public interest litigation from the bench by expanding or stretching the Supreme Court's powers under the article 184 (3) of the Constitution of 1973.CJ Chaudhary first foray into this activist realm was a reaction to the earthquake of October 8, 2005 in Pakistan, when over 75,000 people died. The Court witnessed what it felt was a weak reaction by the government to aid injured and displaced persons and took the opportunity to initiate Public Interest Litigation (PIL) through suo moto provisions of the Constitution under Article 184 (3) to force the government to provide disaster relief. The Supreme Court in two cases, Saad Mazhar v. Capital Development Authority (2005), and Suo Moto Case No.3, 55 PLD SC 5 (2006) handed down decisions against the executive branch, one against the Capital Development Authority (CDA) Islamabad, and the other against the Lahore Development Authority (LDA), institutions that were responsible for urban development. The Supreme Court also took suo moto actions against commercial projects in major urban areas like Lahore and Karachi for the failure of companies to provide for the construction of safe and reliable residential facilities for the people. This was the beginning of media attention to Public Interest Litigation (PIL) and created high hopes among the public regarding the role of the Court (Khan, 2009, 2016; Kokab, 2013; Malik, 2008; Traub, 2008; Waseem, 2012).

After these safety-related cases, the Supreme Court noticed the high rise in the prices of sugar and oil, commodities that average citizens heavily depend upon. In both suo moto cases on 
sugar and oil prices, corruption was the main cause and government policies failed to stop the price hikes. In May 2006, the Supreme Court ordered the National Accountability Bureau (NAB), an independent national investigation agency, to look into the matter. In addition, in the sugar case, the Court fixed the sugar price per kilogram and gave relief to the common people (Ghias, 2010, pp. 993-994).

In November 2006, the Chaudhary Court took notice of another important case, that of "missing persons" or those who were kept in illegal detention by government agencies. In the course of the War on Terror, the Musharraf regime started to arrest persons suspected of terrorism to hand over to the United States. Many of these detainees were secretly held and denied their legal right to appear before a court (Khan, 2008, p. 148). The Human Rights Commission of Pakistan demanded the release of hundreds of people who were in the custody of both civil and military intelligence agencies. The Supreme Court ordered government agencies such as the Ministry of Interior and Defense to produce the "missing persons in the Court." As a result, these detainees became a bone of contention between Mushrraf's military regime and the judiciary (HLSR, 2010, p. 1711). As detailed in the previous chapter, the judicial history of Pakistan was marked by the cooperation of the courts with military leaders in the name of "state necessity" or "revolutionary legality." By directly challenged Mushaaraf's regime on several fronts, the Supreme Court was clearly charting a new path.

The story of the LM actually began when the court ruled against several efforts by the Mushaaraf regime to privatize several public enterprises (which would enrich the regime and its allies). In Watan Party v. Federation of Pakistan, PLD 2006 SC 697, the court declared the privatization of the public steel corporation unconstitutional. This was the first time the court struck down an act of the Musharraf regime (Ghias, 2010, pp. 994-995). Several other such 
efforts involving the Pakistan Telecommunication Corporation Limited (PTCL), Pakistan State Oil (PSO), and Pakistan Steel Mills Corporation (PSMS) engendered a public outcry. When the government sold the Pakistan Telecommunication Corporation to Citibank in 2005, where the current PM worked prior to taking office, protests were widespread and vocal. When the government agreed to sell the Pakistan Steel Mills Corporation to a consortium made up of the Arif Habib Group of Companies, M/s Al-Tuwairqi Group of companies, and M/s Magnitogorsk Iron and Steel Works, Russia, it was challenged in the Supreme Court. Alleging the lack of transparency, corruption, illegality, and a dearth of reasonableness made the deal untenable, the Court declared the agreement null and void (Faqir, et al., 2013; Ghias, 2010; Khan, 2009, 2016; Kokab, 2013). The Court held the Prime Minister of Pakistan responsible for the violation of the rules guiding such sales and privatization of public enterprises.

The decision did not sit well with Musharraf, who declared the "Chief Justice was running a separate and independent government of his own" (Mintz, 2008, p. 2). According to Zafar (2019), General Musharraf was also fearful because his first term as President was nearing its end in the fall. He desired to be elected again, while still wearing the uniform of the Chief of Staff, was threatened by an independent judiciary (p. 459).

A respondent, Senator 1, suggested that the:

Media has taken this issue so strongly that Supreme Court of Pakistan decided to take up the matter and look into the transparency and otherwise of the regularity of the privatization process, and struck it down. Not only the Court struck it down, it also made such observations about the Prime Minister that caused a furor in the Senate and the National Assembly, leading to a bitter debate with demands of the trial of Prime Minister, for making several errors of omission and commissions and causing huge losses to the Exchequer. That certainly was very disheartening for the government. There was a kind of talk how do the judges know what commerce is? How do they know what are the financial requirements, and what financial policies are needed to resolve purely executive matters of the Government. This is interference beyond their jurisdiction but still they were only showing their annoyance. There were some complaints from lawyers and judges from Peshawar which also reached President Musharraf. 
He further added that, "I cannot say about the truth or falsehood of those complaints. However, the Prime Minister was gravely offended by the observations of the CJ which made him [Prime Minister] file a reference against him [Chief Justice]."

On March 9, 2007, General Pervez Musharraf summoned CJ Chaudhary to his office and offered him the opportunity to resign his post or face charges of corruption and misconduct; Chaudhary refused the offer. The action was all the more unprecedented because it was Musharraf in uniform who summoned the Chief Justice to his military camp office. Musharraf grilled him in front of other military commanders, in effect suggesting the ruling threatened state security. The Chief Justice rightly portrayed the manner of the incident in his petition terming it as having 'humiliated his person and his office' and was tantamount to the "subversion of the Supreme Court." In his petition before the Supreme Court later, the Chief Justice explained what happened at the camp office and wrote that President Musharraf looked 'most upset' when the Chief Justice refused to resign and also refused Musharraf's lucrative offer of employment if he resigned (IBA Report, 2009; Kareem, 2009; Khan, 2009, 2016; Kokab, 2013).

The Chief Justice was immediately suspended, taken to his residence and kept under house arrest by intelligence agents and the police. The Chief Justice and his family remained under house arrest for several months. Their telephone lines were cut off, their mobile phones confiscated and their official cars were removed by the police. The Chief Justice and his family, including school age children, were cut off from the outside world, as was the entire residential colony of judges. Musharraf appointed the second senior most Justice, Javed Iqbal, as the Acting Chief Justice under the Article 180 of the Constitution. The senior most Justice of the Supreme Court, Rana Bhagwan Das, was on temporary leave visiting India (Ghias, 2010; Hassan, 2009; IBA Report, 2009; Kareem, 2009; Khan, 2009, 2016; Kokab, 2013). 
On March 13, 2007, the first day of the Supreme Judicial Council hearing of a reference filed by General Musharraf, the suspended Chief Justice Chaudhary came out of his residence and started walking towards the Supreme Judicial Council to appear for his case. He had already filed a petition in the Supreme Court for a stay of the order against his unlawful suspension as the Chief Justice of the Supreme Court. In the process, the police manhandled the CJ and forcefully pushed him into a police van to stop him from reaching the Supreme Court (Khan, 2016, p. 489).

On March 15, 2007, two days after the mistreatment of the CJ by the police, the Musharraf government issued another order of "compulsory leave," i.e., the forcible suspension of Chaudhary as CJ with effect from March 9, 2007 to the date of the submission of the report of the Supreme Judicial Council. The case or reference against CJ Chaudhary was filed in the Supreme Judicial Council, a Constitutional forum to remove superior court judges from their positions as judges. The President of Pakistan files such references/cases against the superior court judges and the Supreme Judicial Council reports back to the President. The order of the removal of a judge is then issued by the President of Pakistan. On April 18, 2007, suspended CJ Chaudhary filed a petition in the Supreme Court against his suspension orders. There were already a number of constitutional petitions in the Supreme Court by the Bar Councils on the same matter. On May 7, 2007, the Supreme Court of Pakistan issued a stay order in favor of the suspended CJ of Pakistan and stopped the Supreme Judicial Council from proceeding further with the case until there was a decision by the full bench of the Supreme Court on the issue (Faqir, et al., 2013; Ghias, 2010; Hassan, 2009; IBA Report, Kokab, 2013).

On July 20, 2007, the Supreme Court of Pakistan set aside the suspension orders of the CJ. The Court declared the "compulsory leave" for judges unconstitutional. The Supreme Court 
declared both orders restraining Chaudhary from working as the Chief Justice of the Supreme Court unconstitutional. The Supreme Court also declared the appointment of the Acting CJ unconstitutional. By a majority decision 10-3, the Supreme Court of Pakistan restored Justice Iftikhar Mohammad Chaudhary as CJ of the Supreme Court. This decision was a blow to the Musharraf regime and it further exposed the hypocrisy of his image as an apolitical figure in the country. However, this was not an end to the conflict between the regime and the Court, rather it was the beginning of a more protracted institutional conflict (Khan, 2016, p.493-494).

\section{November 3 Emergency Plus/Mini Martial Law}

General Pervez Musharraf announced his run for a second term while the Court was hearing a case to determine if he was eligible to run while serving as Army Chief of Staff. According to the Constitution, he could hold only one of these posts. There was a huge risk if he stepped down as an Army Chief, in that he might not be elected as President. The two houses of the Parliament, the National Assembly and the Senate, along with the four Provincial Assemblies served as the Electoral College for the election of the President of Pakistan. There were a number of constitutional petitions in the Supreme Court against the dual office law and there was also a legal point that the outgoing assemblies could not elect an incoming president twice in their one term in office. Only the new assemblies produced by fresh elections could serve as the valid Electoral College for the election of the president (Ahmed, 2012; Faqir, et al., 2013; Ghias, 2010; IBA Report, 2009; Khan, 2009, 2016; Kokab, 2013).

CJ Chaudhary recused himself from the bench and established a nine-member larger Bench to hear the case. On September 28, 2007, by a majority of 6-3, the Supreme Court issued a short order declaring the petitions not maintainable. On one hand, General Musharraf got relief and qualified to run for the Presidency for his second term from the same assemblies who elected 
him five years ago. On the other hand, the Supreme Court on the same matter of the qualification or disqualification for the presidential elections, ordered the Election Commission of Pakistan not to announce the results of the presidential election until the final decision by the Supreme Court on these petitions was released. On October 6, 2007, General Pervez Musharraf was elected President of Pakistan by the outgoing assemblies that were packed with members of Musharraf's Pakistan Muslim League (Q).

An eleven-member bench of the Supreme Court, headed by Justice Javed Iqbal, heard the case regarding whether the Army Chief of Staff could be President in violation of the Constitution. It was expected that the Supreme Court would announce its verdict on these petitions in the first week of November. Musharraf confirmed from his intelligence sources that the Supreme Court would not allow him to contest elections in uniform, i.e., as the Chief of the Army Staff. (Ahmed, 2012; Faqir, et al., 2013; Ghias, 2010; IBA Report, 2009; Khan, 2009, 2016; Kokab, 2013; Malik, 2008). On November 3, 2007, Musharraf proclaimed an emergency, a new term for martial law. As Chief of the Army Staff, he issued three executive orders that suspended the Constitution of 1973, imposed a state of Emergency, and removed more than 64 justices of the superior courts, including the CJ Chaudhary. Then Musharraf issued a Proclamation of Emergency and Constitutional Order. The Constitution of 1973 was held in abeyance. The Justices of the Supreme Court and High Courts were dismissed from their posts and ordered to take a fresh oath on the PCO under the new law of Oath of Office (Judges) Order 2007. In order to resume their duties as judge of the Supreme Court or the High Courts, the judge had to be invited by the government to take the oath of office. Many of the judges were dismissed and were not invited to take oath on the PCO. Some of them refused to take the new oath; only 32 out of 95 judges of the Supreme Court and High Courts did so. On November 3, 
2007, a seven-member Bench of the Supreme Court declared the Proclamation of Emergency and Constitutional Order unconstitutional. However, the armed forces surrounded the compound of the Supreme Court building and prevented this decision from being implemented (Ahmed, 2012; Faqir, et al., 2013; Ghias, 2010; IBA Report, 2009; Khan, 2009, 2016; Kokab, 2013; Malik, 2008).

General Musharraf appointed Justice Abdul Hameed Dogar the new CJ of the Supreme Court. Dogar supported the coup, ruling in Tikka Iqbal Muhammad Khan v. General Pervez Musharraf that General Musharraf's actions, including the Proclamation of Emergency and Constitutional Order, were legal and constitutional. Meanwhile, lawyers, judges, bar councils, political parties, civil society, students and teachers, doctors, engineers, and people from both the print and electronic media formed a social movement, later dubbed the Lawyers' Movement, advocating for the restoration of an independent judiciary and the rule of law. They held massive rallies, protests, and public meetings all over the country (IBA Report, 2009; Khan, 2009, 2016; Kokab, 2013; Malik, 2008).

\section{The Underlying Causes behind the Lawyers' Movement}

While the preceding documented the growing split between the military and the courts, and perhaps just as important between General Musharraf and Chief Justice Chaudhary, one is left to wonder why this period would prove so different from earlier times. Ostensibly, the CJ took on the Public Interest Litigation cases because they were popular and a means of generating important political support for an independent judiciary. However, Supreme Court lawyer Munir A. Malik suggested rather than currying political support, the CJ “... was obsessed with speedily reducing the backlog of cases and that it would be very difficult to reconcile his obsessions with the demands of the bar that the lawyers must be given ample opportunity and time to present 
their case before the court of last resort" (Malik, 2008). Rather than a strategic political move, taking on the public interest litigation was more a housekeeping measure according to this respondent. As it turns out, the events that led to the ouster of the military were more complicated than a simple case of judicial housekeeping. How they spiraled into a broad-based movement for reform is the subject of the next section.

\section{Resistance by the Chief Justice and the other Justices}

The majority of my respondents agreed that the sacking of the CJ and other judges of the Supreme Court and High Courts, 64 in all, sparked the Lawyers' Movement. While it was not the first time in the judicial history of Pakistan that a military dictator sacked judges of the superior courts, it was the first time that the judges and their supporters resisted. According to my respondents, the refusal of the $\mathrm{CJ}$ to accept his dismissal was the single most important factor that triggered the legal community response against the military regime.

\section{Respondent SL 1 argued:}

The turning point was of course the 9th of March 2007, when the CJ was arrested and detained for refusing to resign. Here was a man, the lawyers thought, who was standing up to military dictator - a thing which had never happened in Pakistan. Nobody had ever stood up to an Army Chief and looked straight into his eyes and said no to him.

SCT Judge 2 suggested that the refusal of the CJ to resign, along with the resentment against the Musharraf regime, played a key role in shaping the movement:

...[t]he thing which initiated this movement was that despite pressure on the CJ of Pakistan, Iftikhar Mohammad Chaudhary refused to submit before the military regime. Even the people didn't like Musharraf to remain in power.

\section{HCT Judge 5, added:}

But always laws are silent before the guns. But once the entire judiciary stood behind the CJ of Pakistan, he became their symbol, and wielded the same powers which an Army commander wields over his forces. Not only that, the entire media and people of the Pakistan had showed their disgust against the military dictator's action in crippling and maiming the judiciary of the country. The entire country rose in revolt against the high- 
handedness of the army general who found nowhere to escape the wrath of the people. Thus, in this crisis, people looked upon Iftikhar Mohammad Khan, CJ as their Messiah.

PS Professor 1, pointed to both lawyers and the media as instigators of the Movement.

It was basically lawyers who reacted the way President Musharraf treated the CJ and media was able to show all what had happened to the CJ and therefore lawyers were the first to react... Media played a very important role in their mobilization. In the past, media was very small and was in state control, but by 2007 , the media was free. It was non-state media that also played a very important role in mobilizing support for the CJ.

A professor of history was of the view that:

People were disillusioned, and for them there was no hope that the country will have any change. In such a situation, a resistance movement emerges. He told me that the movement was only sustained because of the lawyers and quite interestingly by the young lawyers, who had no adequate resources to earn their livelihood. Despite these drawbacks, their Bar Councils provided them whatever little funds were at their disposal. Their funds were mostly inadequate to cater to the needs of such young lawyers. Thus, this poor young lot of lawyers barely managed to keep alive to keep up their struggle for the rule of law. The real credit to keep the movement going goes to them.

\section{Resentment against the Military Regime}

A second factor mentioned in interviews was the long simmering resentment regarding military rule among the public, interest groups, and the legal community.

A history professor I interviewed suggested:

... various currents remain present in society, which keep brewing without finding their physical expression until something strange happens, which blows off the lid from the pent-up emotions of the public, eventually leading to an unusual upheaval which was never expected before. The maltreatment of the CJ at the hands of a military general (which was shown live on the national media) released an overwhelming reaction in the public against this heavy-handedness and released all the pent-up feelings against the dictatorial military regime - which was initially spearheaded by the lawyers and later turned into a country-wide agitation - against military rule with the participation of the general public. The military dictator could not stop this mass movement with all the physical might at his command and was ultimately led to give in and leave the country.

Many of my respondents endorsed the idea that standoff between Musharraf and

Chaudhary was the spark that started the Movement. This pretext was enough for lawyers, and

later the general public, to voice their disgust with military rule. The various Bar Councils passed resolutions in favor of the $\mathrm{CJ}$ and demanded the resignation of General Musharraf. 
Senator 1, suggested that people were already fed up with the military rule of General Musharraf:

Pressuring the CJ to resign by a military dictator was the beginning of the Lawyers' Movement, which proved to be the last straw on the camel's back. With the protests and agitations of all the Bar Councils of the country, the Movement assumed threat to the military rule. All kinds of atrocities were let loose on the lawyers; they were beaten, criminal cases were instituted against them and many of them were put behind the bars, but the lawyers withstood all these atrocities, manhandling and imprisonments but did not give in their struggle against the military dictator. This was an unprecedented movement in the country which continued for over two years, and despite the use of violent force against the lawyers, it gained strength with each passing day. It gained the support of the print and electronic media which influenced the general public making it a popular mass movement against dictatorial rule.

HCT Judge 6 focused on the issue of frustration with the military regime before the start

of the LM:

It was nothing except the frustration among the people against President Musharraf's nine years dictatorial rule. In fact, it expressed public indignation against the military rule. It was the release of cumulative frustration of the public against Musharraf's undemocratic rule in the country.

\section{The Role of Political Parties}

In London on July 12, 2007, the All Parties Democratic Movement (APDM), an alliance of 32 political parties of Pakistan was established at the meeting of All Parties Conference of the heads of the respective political parties. The major parties attending were the Pakistan Muslim League (N) (PML-N), PakistanTehreek-e-Insaf (PTI), Pakhtun-Khwa Milli Awami Party (PMAP), Muttahida Majlis-e-Amal (MMA), and the Awami National Party (ANAP). These political parties devised a plan to oust General Musharraf from power. The APDM also supported the cause of the lawyers to restore deposed judges to the courts and to ensure the independence of judiciary and the rule of law in the country. The leaders of two of the largest national-level political parties of Pakistan, Benazir Bhutto of Pakistan People's Party (PPP) and Mian Muhammad Nawaz Sharif of the Pakistan Muslim League (N) were in exile. Sharif was 
forced to leave the country by Muharraf after he was convicted in a plane highjacking case where he was sentenced to life imprisonment. Later under an agreement, the deposed P.M. was sent into exile in Saudi Arabia on the promise to not take part in Pakistan politics. The government of Saudi Arabia was the custodian and guarantor of this agreement (Ahmed and Stephan, 2010, p. 496).

Mohtarma Benazir Bhutto went to United Kingdom and preferred to stay there in selfexile. However, she was active in politics and kept her political party intact in Pakistan. On the other hand, majority party leaders or Members of Parliament of Pakistan Muslim League (N) of Nawaz Sharif joined a new political party, the Pakistan Muslim League (Q) organized by General Pervez Musharraf and his close associates. PML (Q) won the general elections held in 2002 and next elections were due in January 2008. On December 15, 2007, the government promulgated five Presidential Ordinances to lift the Emergency and repealed the Constitution of 1973 with necessary Amendments (Khan, 2016, p.510).

Both Benazir Bhutto and Nawaz Shairf were planning to return to Pakistan to participate in general elections scheduled on January 8, 2008. Benazir Bhutto was in close contact with Musharraf and both had secret meetings in the United Arab Emirates to make a deal. Musharraf, who already had been elected President of Pakistan for his second term, knew that he needed the cooperation of at least one major opposition party to remain in power. Thus, he made a deal with Benazir Bhutto and allowed her to come back to Pakistan and gave her immunity from those cases which were still pending in the courts. Bhutto returned to Pakistan on October 19, 2007. The same day, there was a bomb attack that targeted Benazir Bhutto for assassination and killed 120; she survived. Because of this attack and protests against it, general elections were postponed until February 8, 2008 (Ghias, 2010, pp. 41-42). 
On October 5, 2007, Musharraf promulgated a National Reconciliation Ordinance 2007 (NRO) to grant a pardon or immunity to Benazir Bhutto and other politicians and political workers of political parties including Muttahida Qaumi Movement (MQM) and the PPP from prosecution in corruption cases (Amin, 2015, p.266) . Through international pressure, General Musharraf had to extend the same offer to Mian Nawaz Sharif and his political party. On November 25, 2007, Sharif returned to Pakistan on the Saudi royal family's private jet. Both political leaders broke their exile and came back to Pakistan to contest general elections. On December 27, PPP leader Benazir Bhutto was assassinated after a political rally in Rawalpindi, a city close to the capital Islamabad. However, her political party PPP won the majority of seats in the general election and formed a coalition government. Nawaz Sharif's political party PML (N) also joined the coalition. Pakistan Muslim League (Q), General Pervez Musharraf's ally political party lost the elections. Now two major opposition parties of the Musharraf regime were in power. Syed Yousaf Raza Gillani of the PPP became the Prime Minister of Pakistan (Amin, 2015, pp. 266-267).

The LM had gained the attention of all kinds of segments of the society including political parties. The lawyers were in the streets calling for their demands. They were fighting for the restoration of judges suspended by General Musharraf at the time of the National Emergency imposed on November 3, 2007. They stood for judicial independence and the rule of law in the country. They also demanded the resignation of General Musharraf as Chief of the Army Staff and as the President of Pakistan. The LM achieved one major success when President Musharraf stepped down first as Army Chief on November 28, 2007 by handing over command to General Ashfaq Parvez Kiyani, and later resigned as President on August 18, 2008 fearing that the PPP government could impeach him if he did not. On September 6, 2008, Asif Ali Zardari, widower 
of former Prime Minister late Benazir Bhutto and now co-chairperson of PPP became the President of Pakistan (Zafar, 2019, p.472).

Almost all political parties in Pakistan, except a few such as the Pakistan Muslim League (Q) and Muttahida Qaumi Movement (MQM), supported the Lawyers' Movement. Their leadership called for judicial independence, the rule of law, and the restoration of all judges suspended by General Pervez Musharraf on November 3, 2007. The PPP led Government incrementally restored most of the sacked judges (Khan, 2016, pp. 527-528).

On March 11, 2009, Pakistan Muslim League (N), Tehrik-e-Insaf, and some other political parties started the Long March for the restoration of the remaining justices. They started from Lahore, and their destination was the capital city Islamabad. They decided to go by way of the Grand Terminal road instead of the motorway to be able to pass more major cities and to attract larger crowds. Thousands of people joined the Long March under the leadership of Nawaz Sharif and CJ Chaudhary. When this huge crowd reached Gujranwala City, between Lahore and Islamabad, Aitzaz Ahsan, a renowned Supreme Court Lawyer and a chauffeur of the deposed CJ throughout the Lawyers' Movement, received a phone call from Army Chief General Ashfaq Parvez Kiyani saying that he had talked to the Prime Minister about the restoration of Chaudhary as CJ of the Supreme Court of Pakistan (Gall, 2009). The Chief of the Army Staff requested the leaders and the participants of the Long March call off their protest after his assurance that Prime Minister make the restoration announcement soon.

On March 16, 2009, at 3:00 a.m., Prime Minster Yousaf Raza Gillani in a televised address to the nation announced that the government would restore Chaudhary and his four other colleagues by issuing an executive order of the Government. The U.S. ambassador to Pakistan Anne Paterson and Richard Holbrook urged leaders of both political parties to resolve the issues 
amicably. U.S. Secretary of State, Hillary Clinton and British Foreign Minister David Miliband exerted pressure on President Zardari to negotiate with Nawaz Shaif on the issue of the restoration of Chaudhary as the CJ of the Supreme Court (Ahmed, 2010, p. 502).

On March 21, 2009, on the retirement day of CJ Abdul Hameed Dogar, the LM achieved another milestone by forcing the PPP regime to reinstate the leader the CJ of the Supreme Court. After the restoration of all judges deposed by General Pervez Musharraf, the supporters of the LM dubbed their success as the success of the judicial independence and the rule of law in the country. This was the end of the two-year long struggle of judges, lawyers, and the civil society in the form of a social movement, the Lawyers' Movement, which started on March 9, 2007 when General Musharraf suspended the CJ of the Supreme Court (Khan, 2016, p.527).

SL 3 said to me on the restoration of CJ Chaudhary that:

So, the lawyer's leadership has been instrumental inspiring people to come and join us in this cause, the cause of rule of law where the Chief Justice cannot be kicked out by a military dictator like in this manner against the law, against the constitution. So that was the beginning. With the passage of time we were becoming more and more clear in our objective that we want to end the dictatorship. So, when he was restored the first time under the judgment of thirteen judge bench of the same court we, first that we announced that day that the first phase of our movement is over that we wanted the restoration of the Chief Justice.

\section{The Role of the Media}

Before General Pervez Musharraf's rise to power in October, 1999, there were only two state-owned TV channels in the country. General Musharraf's regime issued licenses to private TV channels that were free and independently owned by private owners, most of them were the owners of renowned national newspapers. Suddenly there were hundreds of private TV news channels. During the Lawyers' Movement, these channels played a key role in educating and awakening the general public regarding the LM and its impacts on the Pakistani society moving forward. There was another perception among the journalist community as one of my 
participants, a senior anchor on a well-known news channel, mentioned that both print and electronic media considered that after the attack on the independence of judiciary, the next to be targeted would be them. Thus, the media stood with the lawyers and the judges not only to protect the courts, but to also preserve their own freedom (Bolognani, 2010; Faqir, et al., 2013; HRW Report, 2007; Khan, 2016; Kokab, 2013).

Ghias (2012) explores that when Chaudhary became Chief Justice of the Supreme Court in June 2005, he started taking a very keen interest in the projection of the Court performance in media. His critics, mostly lawyers, blamed him and called his actions a "media circus." According to his critics, the suo moto notices by the CJ were taken for his own self-promotion. The annual Supreme Court Report 2006 included a separate section named "Supreme Court and the Media" which consisted of 18 press reports (Ghias, 2010, p. 998). However, his passion for media coverage helped him greatly, especially when he stood up to dictatorial acts of the Musharraf regime. Once the regime imposed a ban on TV stations airing live coverage of the movement, other mode of communications -- videos on YouTube, homemade blogs, Flickr, websites, and cell phones -- were employed (HLSR, 2010, p. 1717).

The electronic and print media played an important role in highlighting and framing the activity of the Movement. Media showed live coverage of the events of the LM: the processions led by CJ Chaudhary, meetings of the District bar councils, the addresses of the Movement's leaders, and the atrocities of the police, creating anger and depression among the masses and shifting the public's view of Musharraf to that of an oppressor (Khan, 2007, pp. 24-25). 
Figure 5.1. March 13, 2007, Mistreatment of Police with the Deposed Chief Justice

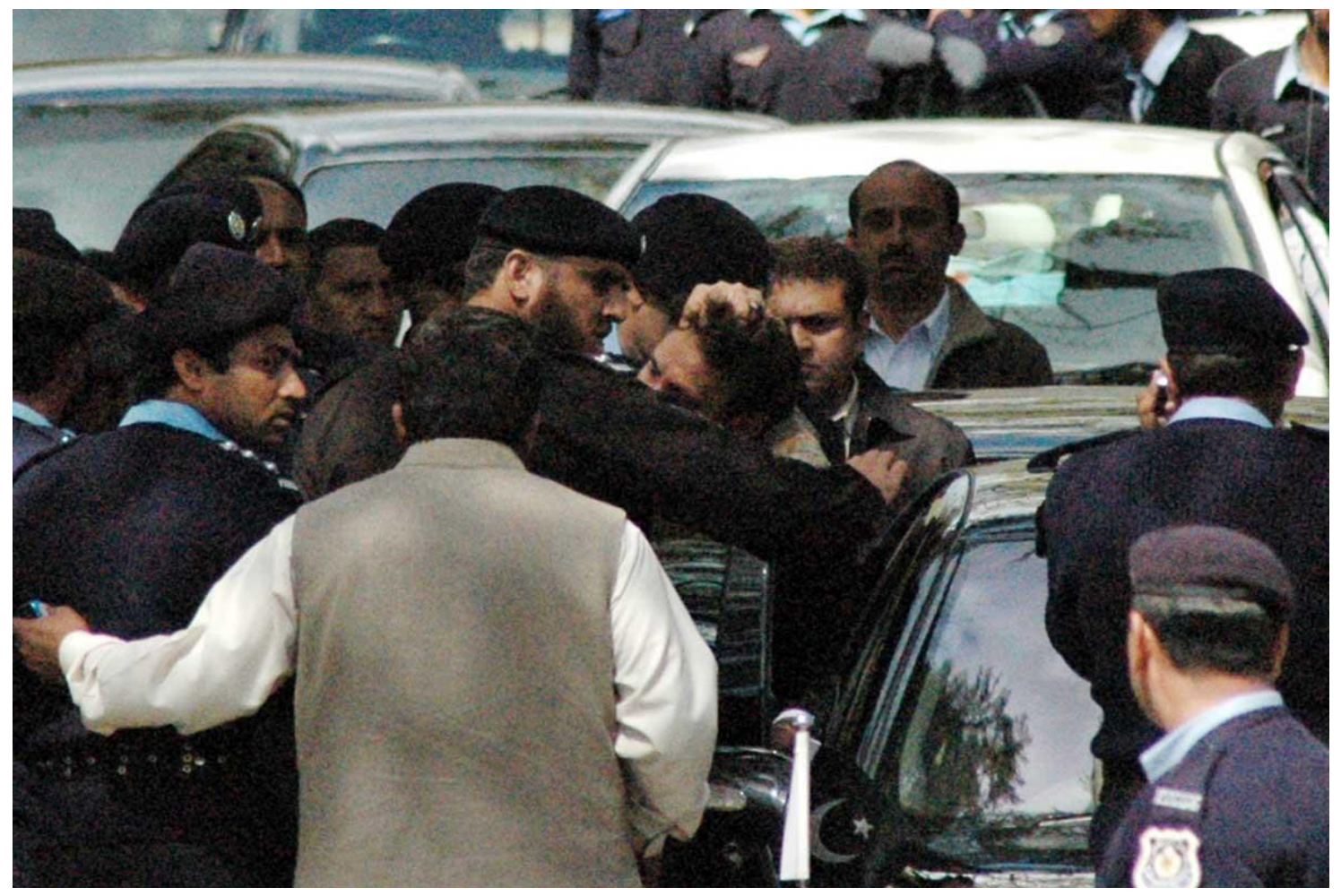

Figure 5.1 shows police manhandling of deposed CJ of Supreme Court Chaudhary on March 13, 2007. These and other images of the police mistreatment of the Chief Justice were broadcast on TV channels, made it to the front page of most newspapers and dominated the electronic media, sparking a public outcry (Ahmed, 2012; Anwar, 2009; Bolognani, 2010; Ghias, 2010; IBA Report, 2009). The private TV channels gave unprecedented coverage to the meeting when Musharraf summoned the Chief Justice to the Army House Camp office on March 72007 , a first for Pakistan. The public accepted the media and court's framing of the meeting as an assault on the independence of the judiciary and the rule of law (Anwar, 2009, p. 29). A senior journalist and a TV anchor suggested the incident, and its coverage, gave an unprecedented impetus to the LM. According to him, the initial public response to the suspension of the CJ was non-existent until the confrontation with the police, which produced "the picture which started the LM." 
Several respondents suggested that media framing of the events was important in generating public support for both the LM and the end of military rule. The media, which highlighted the highhandedness of the police, were, according to SCT Judge 1:

[a] great help for allowing the lawyers and ex-judges to formulate the issues that were involved in those cases, which on intervention were called emergency, partial suspension or emergency plus on 3rd of November'2007. The lawyers' community appearing on the media, from the evening it was announced they clearly formulated the issues for the nation and presented them to the nation, spurred the Movement itself. Had there been no projection of the rallies and agitations of the lawyers by the electronic and independent media, it was likely that the dictator had temporarily succeeded in suppressing public agitation against Musharraf.

PS Professor 2, suggested:

There are three major supporters. First, media has become very powerful institution in Pakistan. New channels and their anchor persons or journalists exercised such autonomy which they had never exercised before in the history of Pakistan. Second was a new civil society. One thing common among the three strands - the civil society, the media and the lawyers - was a new generation of the general people who were committed to the idea of a new Pakistan and new Pakistan could not be other than a Pakistan based on democratic principles, rule of law and constitutionalism.

Even a respondent I interviewed who argued the LM was an "elite" group of self-

interested lawyers, had to admit:

Had he [the CJ] not said NO to the General, the latter would have probably remained in power for an indefinite time but for the media, which was healthy, robust and vibrant and did not let it happen that way.

\section{The Role of Civil Society}

Civil society played a significant role in the rise and success of the Lawyers' Movement. Historically, mostly political parties and political activists participated in anti-military movements for the restoration of democracy in the country. However, in the LM actions against the dictator, almost all segments of civil society, including women organizations, teachers' associations, journalists, columnists, TV anchors, associations of retired people, students, labor and workers' organizations, doctors' group, engineers, traders, business organizations, NGOs, 
and overseas Pakistani organizations were involved. While the judges, lawyers, the bar associations, and District bar councils were at forefront of this Movement, later to be joined by the political parties, the legal community drew on and used the political support of the broader society to effect change. Zaidi (2008) rightly regarded this movement as the "broadest-based, and longest-sustained" in the history of Pakistan.

Ahmed (2010, pp. 495-496) argues the civil society groups that actively participated in the Lawyers' Movement: included the Joint Action Committee for Citizen Rights, the Women's Action Forum, the Human Rights Commission of Pakistan (HRCP), the Aurat Foundation, ASR Resource Centre, Christian Study Centre, Omar Asghar Khan Development Foundation, Sungi Development Foundation, Strengthening Participatory Organization (SPO), the Pakistan- India People's Forum for Peace and Democracy, the Sustainable Development Policy Institute, and Shirkat Gah, workers and organized labour, notable workers from the Brik Kiln, from the Pakistan Bhatta Mazdoor Union, the Labour Party Pakistan, and the National Workers Party. A respondent, CSR 2 said:

Everyone had ownership of that movement. They were so many of them, it was so, you had to be there to imagine what it was like, it was not like taken as a herd like cattle, that go there and who this and who that, no everyone thought himself or herself as a leader. There were so many leaders at every level, at district level, at city level, at all levels, and since it was a combination of many organizations...... it was an organized movement... Organized movement but I'm saying everyone was on the same page and nobody was saying that this is my movement, it was, and this is what I'm trying to tell you. The leadership was there off course, without the leadership it would have been impossible but it was not about one leader, there was a group of leaders.

A respondent, CSR 2 further added:

Many organizations, for example Women Action Forum was there from the very first day, and then Khaksar Tehreek was there, Labor Union was there, joint action committee was there, Aurat Foundation was there, and there were so many others who lent their weight to the movement. Justice and Peace Society and Student Action Committee were born after the emergency was declared. On November 3' 2007, when the emergency was declared, next day we were a group of people, who were having a meeting in the HRCP 
(Human Rights Commission of Pakistan) auditorium where all 55 of us were arrested -24 women and 31 men. So, when we came out of jail, we formed this CCP (Concerned Citizens of Pakistan) and the idea was to consult all the civil society organization and make a strategy.

\section{The International Role}

The Pakistani diaspora all over the world, in particular in Europe, North America, and the Middle East sent financial support to the LM. Political parties in Pakistan mobilized their overseas organizers and workers to raise funds for the restoration of an independent judiciary in Pakistan. An emerging political party, Pakistan Tehreek-e-Insaf of Imran Khan appealed to its overseas supporters to establish a "Long March 2009 Fund" to fund the lawyers' struggle against the Musharraf regime. As far as the international legal community is concerned, renowned world organizations such as the Commonwealth Lawyers Association, the South Asia Bar Association, Amnesty International, the International Commission of Jurists (Geneva), and the International Federation for Human Rights (Paris) sent delegations to Pakistan to investigate the situation and to support the Lawyers' Movement's struggle for an independent judiciary and the rule of law in Pakistan. Similarly, many US-based organizations worked with Pakistani legal community to support the LM goals.

The US-based National Lawyers Guild (NLGF) sent a fact-finding delegation to Pakistan. US lawyers headed by Devin Theriot-Orr formed a combined group of lawyers named the Pakistan Justice Coalition (PJC) to raise awareness in the US society about the legal and constitutional issues of Pakistan, and arranged the visits of Pakistani lawyers to the United States. The National Lawyers Guild Foundation (NLGF) also arranged visits of US delegates to Pakistan to analyze the impacts of the November 3 Emergency on the independence of the judiciary and the rule of law in Pakistan, along with the media and upcoming elections. The Harvard Law School awarded its most prestigious award, the Medal of Freedom, to deposed CJ 
Chaudhary. The renowned US National Law Journal declared him its 2007 Lawyer of the Year, becoming the first non-American to receive this prestigious award (Ahmed, 2010, pp. 507-508).

One of my respondents, SCT Judge 3, took an oath based on the PCO of General Musharraf, and was later forced to step down after the Supreme Court judgment regarding this order. He argued that the LM was an international conspiracy, and that the US government was a collaborator in this scheme to restore Chaudhary to the Supreme Court:

That was a political movement and it was also (although I don't have any evidence to substantiate that the American Government had also supported was correct or not because it is recorded) said that the American Government especially Vice President, Joe Biden, who, when the Movement started, was in the opposition, (he was a Senator) then in due process he came, and became the Vice President and it was said, although I repeat, I don't have any evidence to substantiate. It was also in the paper. According to my opinion, it was an international conspiracy to restore Justice Chaudhary and when they included the substantial political parties who subsequently gained advantage. So those were the beneficiaries - Nawaz Sharif was the beneficiary.

\section{The Law Community}

Finally, I would be remiss not to mention the law community itself as a major factor in the reform effort. There were a total 160 Bar Councils and lawyers' associations in the country at the time of the Lawyers' Movement, with over 9,000 lawyer members. This was the largest organized body within the movement. Among these, the smallest, but most efficient and effective, body was the National Action Committee of Lawyers. Prominent lawyers like Aitzaz Ahsan, Ali Ahmad Kurd, Munir A. Malik, Hamid Khan, and Justice Rtd. Tariq Mahmood have all been president of lawyers' associations such as the Supreme Court Bar Association and the Pakistan Bar Council. The organizational structure of the Lawyers' Movement was comprised of four tiers: 1) The National Action Committee of Lawyers; 2) the Pakistan Bar Association and the Supreme Court Bar Association of Pakistan; 3) Provincial bar associations such as the Lahore High Court Bar Association, the Baluchistan High Court Bar Association, the Sindh High Court Bar Association, the NWFP Bar Council; and 4) City-Level bar councils in Karachi, Lahore, 
Peshawar, Quetta, Islamabad, Multan, and Faisalabad (Ahmed, 2010, pp. 502-503). However, there was not an 'organized' mechanism to make important decisions. Rather the process of decision-making was quite haphazard and at times disorganized. A Harvard Law School Report (2010) suggested that top lawyers like Aitzaz Ahsan, Ali Ahmed Kurd, and Munir A. Malik directed the major strategy of the LM from above. However, much of the movement's impetus was generated from the bottom by the youngest and poorest lawyers.

A respondent, SL 1, talked about decision-making process during the Movement.

Joint Committee came up later but we acted through bar associations. The lawyers had one significant attribute. There is a bar association in every corner of the country and its management is elected every year, every year you have elections, democratic elections. So, the most significant role was thereafter played first by the presidents of provincial bars, then the presidents of the district bars, and the lawyers of the district bars. Now, it was difficult to run a movement without funds, without any funds, we didn't open a bank account, asked for no donations, but for our major activities, we asked people to contribute in buses like the Long March, or we asked was people organizations, or business men of chambers of commerce or bazar or markets to contribute to us the transport we needed massive transport to take (almost more than a hundred thousand people from all parts of Pakistan to Islamabad) and to sit in front of Parliament, to congregate in front of Parliament. Then there were about two hundred thousand people that came from the adjoining areas they converged. We had, at least a hundred thousand people into Rawalpindi and then the twin city Islamabad. Although the catchment area was really the closest town, people contributed vehicles in hundreds and the other thing we wanted was simple food, cooked rice, rice cooked in grams. And we got massive, mountains of food from there. People were so happy to contribute to the movement.

Most of the material resources for the LM were donated by the lawyers themselves

(Kokab, 2013, p. 188). As some scholars like McCarthy and Zald (1977), Oberschall (1973), and Meyer (2014) have emphasized the significance of resource mobilization and entrepreneurial aspects for the success of movements and mass protests, the leaders and the proponents of the Lawyers' Movement also understood the importance of resources and their mobilization. According to Ahmed (2010), the beginning of the donations came from Lahore High Court Bar Association when they raised 1000 Pakistani rupees (\$12), and later they raised 80,000 rupees 
(\$1000). The lawyers' organizations in major cities and districts campaigned for donations and raised money throughout the movement. The major financers were two major political parties, Mian Nawaz Sharif's Pakistan Muslim League, and Imran Khan's Pakistan Tehreek-e-Insaf (Ahmed, 2010, p. 504).

One of my respondents, CSR 2, replied to my question on how this movement was sustained despite the fact that most young lawyers were out of work said:

I tell you, when we used to take out a rally, they were always people there, they were planted by I don't know who or may be genuinely whatever and they used to come and ask "where are you getting your funding from", "how is it possible that you know bullshit", there was no funding, yes there were funding at different levels of different kinds but not like somebody from outside. We were raising our own funds and remember the civil society is very affluent in Pakistan. The people who were involved in the Movement, you have no idea the way they donated it. They had coasters, they had people, they had money, they had everything. So we never had a problem about resources, never. The other thing is we were collecting, the day we came out of the jail; we said we need to collect funds and to give to the lawyers, poor lawyers who are sitting on. We collected funds and used to collect funds on regular basis, but used to have no fund raisers as such. We used to have meeting with the people who used to come and donate.

\section{Objectives of the Lawyers' Movement}

When I asked my respondents what were the main objectives of the LM, a consensus formed around independence of the judiciary, establishing the rule of law, restoring the judges deposed by the military regime, reestablishing the supremacy of the Constitution, protecting fundamental rights, restoring democracy in Pakistan, and removing General Mushraff from power.

Senator 2 confessed that:

...[y]es, obviously the main objective of the LM as such, or the main goal of the lawyers was the independence of judiciary. I think that was very clear that it was a movement for the restoration of an independent judiciary.

SL 4, recalled:

Yes, this was the first speech that Mr. Munir A. Malik made. I mean, if you see all the speeches in which we have talked about independence of judiciary and rule of law. $\mathrm{He}$ also said that we are not here to reinstate judges and to give them jobs. We are fighting 
for independence of judiciary and not for their persons. There were a set of discussions whether everybody should be restored or at a minimum that the CJ should be restored. My own view was that, everybody should be restored.

PS Professor 1, explained that the:

...[i]mmediate objective was restoration of the CJ, especially when Musharraf removed other judges after imposition of emergency. So, constitutionalism, rule of law and restoration of the judiciary were the main objectives and shared by all.

PS Professor 2 argued “... [c]ertainly, they wanted an independent judiciary and they thought that Pakistan will never be a democracy if the rule of law was absent and no rule of law is possible without an independent judiciary." Similarly, a law professor, when asked whether there was a relationship between the LM and judicial independence, answered "...[y]es, one hundred percent and a very strong relationship."

Reading the addresses and speeches of the leaders of the movement, reinforces the preceding, clearly identifying judicial independence as a goal of the Lawyers' Movement.

On November 17, 2008, Chaudhary addressed the members of the New York City Bar Association:

No democracy can survive without an independent judiciary. No strong and stable Parliament can be constructed on the ruins of an independent judicial edifice. An independent judiciary is, in fact, the most significant protection available to Parliament. It covers the flanks of Parliament, resisting attacks from any adventurer in the wings........ The Lawyers' Movement in Pakistan is a unique and historic struggle against all those forces which are trying to stifle the rule of law and are uprooting the foundations of our judiciary. They are trying to suffocate and bury the concept of an independent judiciary once and for all, and once that happens, then the very fabric of society is destroyed resulting in a domino effect, with all the other organs and pillars of the state falling one by one. This movement is being led by the young lawyers of Pakistan who seek neither office nor power.

He continued by explaining the concept of an independent judge and said:

My fellow jurists permit me to emphasize one additional point. Just as an independent judiciary is vital to sustain democracy, the independence of judiciary itself is dependent entirely on "independent judges". For a truly independent judiciary, the judges must be independent and fearless. If judges are afraid of being arrested, of being manhandled, of 
being imprisoned along with their families, and that too because they had the courage to take a principled stand against a dictator (Pervez Musharraf) and refused to be party to the mutilation of the Constitution, then we might as well forget about any judge ever being independent or fearless. If society turns a blind eye and condones the illegal acts of the dictator (Musharraf), then we might as well bury the hope of ever having free judges with free minds and a free conscience. Ladies and gentlemen, this is why Pakistan is going through a decisive and definitive moment in our history.

The president of the Pakistani Supreme Court Bar Association, Munir A. Malik,

addressed the same meeting and said:

Our Supreme Court has frequently stressed the importance of an independent judiciary, particularly in reference to Article 175 of the Constitution. It is observed, inter alia, in the Al-Jehad Trust case (PLD 1996 SC 324) and the Mehram Ali case (PLD 1998 SC 1445) that 'the independence of judiciary is inextricably linked and connected with the process of appointment of Judges and the security of tenure and other terms and conditions,' and that the 'framers of the Constitution were mindful of the fact that in the absence of security of tenure no Judge can function impartially and independently.' In the absence of an independent judiciary that is able to freely exercise its judicial functions and enforce the law without interference, the Fundamental Rights guaranteed to citizens under our Constitution are illusory and not worth the paper they are written on. Saleem Akhtar J held as much in the case of Govt. of Balochistan v. Azizullah Memon (PLD 1993 SC 341) when he observed: 'Separation of judiciary is the corner-stone of the independence of judiciary and unless the judiciary is independent, the fundamental right of access to justice cannot be guaranteed.

He further elaborated on the struggle of the lawyers for the independence of judiciary:

Fortunately, our nation has woken up to this peril. There is unanimity within the legal community and the general public that the ideals of the separation of powers and independence of judiciary are worth preserving. The Rule of Law is not merely an empty slogan but a reality worth striving towards. Montesquieu had warned, 'The tyranny of a prince in an oligarchy is not as dangerous to the public welfare as the apathy of a citizen in a democracy.' We have averted the greater danger. We are only left with the lesser threat. And now that the people are awoken from their slumber and apathy, their will shall prevail. As Justice Sandra Day O'Connor of the U.S. Supreme Court pointed out "Constitutions and statutes don't protect judicial independence, people do." But the people Justice Sandra Day O'Connor referred to were not simply members of the general public. She was also referring to people who practice at the Bar. She was also referring to the people who were on the Bench. Judges, like the rest of us, also form a part of Pakistan's civil society. There is a mutual covenant between all sections of civil society to uphold the rule of law and secure the independence of the judiciary. Any section that betrays this mutual trust, in addition to injuring the others, also imperils itself. 
On February 7, 2009, Chaudhary again expressed his views while speaking at an oathtaking ceremony held under the aegis of the Lahore High Court Bar Association (LHCBA) in Rawalpindi and said, "I congratulate the nation that after 60 years of its life, it has reached the conclusion that the establishment of an independent judiciary and the rule of law is a prerequisite for prosperity of the country." Justice Ejaz Afzal, a deposed judge of the Peshawar High Court, in his address said that, “...[r] einstatement is not important for us, what is important is that the judiciary of tomorrow should be free from all pressures."

Despite the fact that leaders of the Lawyers' Movement had a number of objectives in their mind which they expressed in their addresses to the law community and the people, there was a consensus among the participants that the restoration of an independent judiciary was one of their major goal along with the rule of law, restoration of deposed judges, and healthy democratic values.

\section{Conclusion}

For more than 24 months, civil society in Pakistan stood against the dictatorial regime of General Pervez Musharraf in order to achieve the independence of judiciary and rule of law in the country. In 2007, Musharraf sacked more than 64 judges of the superior courts, including the CJ of the Supreme Court Iftikhar Mohammad Chaudhary and kept them under house arrest and police custody. The lawyers of Pakistan with the help of a vibrant civil society started a significant resistance, the Lawyers' Movement, against the military might of General Pervez Musharraf and set the goals of an independent judiciary through the restoration of all sacked judges.

This chapter is a case study of that struggle of lawyers and civil society for the restoration of deposed judges of the superior courts, and ultimately for the struggle for independence of 
judiciary and rule of law in the country. My work on the Lawyers' Movement adds to the literature on cause lawyering. Large parts of the Pakistani legal community and bench risked their professional careers to take a firm stand for the principles of the independence of the judiciary and the rule of law in the country. Despite the fact that the many lawyers' incomes were wholly dependent on their daily appearances before the courts, they boycotted the courts. They continued their struggle for over two years without any means of income, taking rallies on the streets and roads, faced brutal treatment by the police by being subjected to baton charges, tear-gas, illegal detentions, house arrests, police raids at their houses, and loss of life, and all to restore the lost respect of the courts. This type of widescale professional resistance was and is unprecedented in the world. The legal community in Pakistan, with the support of a vibrant civil society, fought valiantly and succeeded in restoring the basic human legal rights in the form of a free judiciary and the rule of law.

This chapter not only examined the story or evolution of LM since March 2007, but it also focuses on the underlying causes of the Movement such as public resentment against the military junta, and the police brutality against the bench and the bar. These thuggish measures had two main aims: to perpetuate military in the country, and to make a dictator the final arbiter for the country, a law unto himself. It also highlighted the role of modern media, the role of political parties and civil society including students, teachers, doctors, engineers, and the pressures of international governments and non-governmental institutions.

The role of the progenitors, leaders, and supporters of the Lawyers' Movement played an important part in awakening the general consciousness of the public against the repressive measures of military regime. There were also the opponents of the Lawyers' Movement, most of whom had benefitted from its favors, and who supported the military regime. But against the 
juggernaut of popular social and political protests, these opponents failed in all their attempts to block change in society. 


\section{Chapter 6}

\section{The Impact of the Lawyers' Movement}

\section{Introduction}

In this chapter I examine the impacts of the Lawyers' Movement (LM) on both judges and the courts in Pakistan. I believe that the LM paved the way for the judiciary to challenge political regimes with freedom and dignity. This chapter will analyze the role of the LM in promoting judicial independence and democratic values in the country. This social movement is responsible for bringing changes to the structure and functioning of the courts, in the behavior of judges and staff, and in the attitudes of the public towards the judiciary. Finally, I will analyze these changes and their impact on Pakistani society and on the democratic health of the country.

\section{The Impacts of Social Movements}

There is a voluminous literature on the impacts of social movements. Some researchers have focused on the cultural impacts of social movements, e.g., on ideas, values, media, popular culture, and on public opinion and everyday behavior (Bonastia, 2012; Earl, 2004; Fetner, 2016; Halfmann, 2011; Luker, 1984; Eyerman \& Jamison, 1991; Rochon, 1998). Recently, researchers have shifted their interest to trace the political impact of social movements to other contemporaneous developments, in particular, the social movement's impacts on non-political institutions and organizations such as science, business, and education (Amenta et al., 2010; Arthur, 2011; Epstein, 2016; King, \& Pearce, 2010). Some scholars have also analyzed the impact of social movements on music, art, fashion and on how social movements benefit concerned constituencies (see Amenta \& Young, 1999; Giugni \& Grasso, 2016; Roy, 2013; Taylor \& Van Dyke, 2004; Whittier, 2004). 
Amenta and Polletta (2019) argue that the most significant impacts of social movements are cultural. Social movements change the world we live in; some changes are appreciable others are not. The authors define culture broadly: "meaning-making dimensions of all policies and practices." They organize the literature on the impacts of social movements in four wider groupings: "1) public opinion and everyday interactions; 2) media coverage and popular culture; 3) nonpolitical institutions; and 4) policy and political institutions." According to the authors, existing scholarship on movements' impacts is mostly focused on the US and it could be strengthened by expanding its attention to cross-national, cross-cultural, and historical cases. A social movement's impact is shaped by the capacity of the institutions to be responsive and dynamic. Whether a social movement becomes an agent of social change in the society is largely dependent on the movement's organization, resourcefulness, and strategy. The authors suggest that the different forms of change, in particular policy and political institutional change, occur due to the "institutional contagion" factor, or when change in one institution inspires change in other institutions (Amenta \& Polletta, 2019, pp. 291-292).

Ahmed and Stephan (2010) emphasize the political institutional impact of the peaceful and nonviolent Lawyers' Movement in Pakistan. This movement has had far-reaching political impacts on Pakistan's political landscape, from an individual act of defiance by the CJ Iftikhar Mohammad Chaudhary to the restoration of an independent judiciary and rule of law in the country. According to Ahmed and Stephan, the LM was a peaceful, nonviolent, united and disciplined grassroots struggle against the repressive regime of Musharraf, as well the rule of the PPP, which endorsed the dictator's autocratic actions. The transfer of power from a military dictator to a civilian political government was itself a great success perhaps most importantly, the restoration of deposed judges, including the CJ of the Supreme Court, paved the way for the 
judiciary to act as an independent institution in the country. Through this movement, lawyers made an alliance with opposition parties and other civic organizations in the country to achieve their goal of the restoration of an independent judiciary. The authors also admit that the LM had a great impact on Pakistani civil society in terms of creating political and social awareness (Ahmed and Stephan, 2010, pp. 492-493).

\section{The Judicialization of Politics}

The judicialization of politics, whose roots can be traced to the adoption of written constitutions and independent and free courts, may become the most significant future global trend in governance (Tate and Vallinder 1995). The conditions that favor the expansion of judicial power are also expanding, such as liberal democracies, separation of powers, a politics of rights, interest and opposition groups using courts, ineffective majoritarian institutions, the positive perception of the courts by the public, and most importantly, the rise of judicial activism. Vallinder (1995) presents two major aspects of the concept of judicialization of politics: (1) the process by which courts and judges come to make or increasingly dominate the making of public policies that had previously been made by legislatures and executives, and (2) the process by which non-judicial negotiating and decision-making forums come to be dominated by quasi-judicial (legalistic) rules and procedures (p. 26).

Stephenson (2003) investigates the puzzle of judicial independence along with the situations when and why public opinion supports the judiciary against the other branches of the government. He finds different sources of judicial power. He develops formal models to measure judicial power and examines how the stable competition among various political rival forces, such as political parties, allows and facilitates the courts to exert their judicial power. 
Favoreu (1992) includes three indicators of judicialization of power: 1) a move towards court-like processes and procedures in the affairs of the administration; 2) enhancement of judicial powers over administrative matters; and 3) an increase in the judicial review. Landfried (1985) argues that it is a shift when political decision-making is taken by the courts instead of political institutions. In the 1990s, researchers in the field of comparative politics started to develop theories and models to understand the behavior of various institutions including courts. Stone (1992) emphasized the evolution of institutional behavior of policy making institutions.

Hirschl (2004) reinforces the argument that "judicialization" or empowerment of the courts is expanding because of the fact that the political, social, and economic power-holders estimate that judicial autonomy serves their interests in the long run. Hirschl analyzes legal, political, and constitutional reforms in Canada, Israel, New Zealand, and South Africa. According to him, constitutional revolutions in these countries were not driven by genuine commitment to democratic values or universal rights, but by a strategic self-interested coalition of politico-economic and judicial leaders.

Hirschl (2008) tracks a shift of the courts' role away from flashy rights issues to matters of "outright and utmost political significance." Hirschl groups these into five major types: 1) electoral processes and outcomes; 2) core executive prerogatives; 3) legitimacy of regime change; 4) transitional justice; and 5) defining the nation via courts. The author also analyzes the political backlash of the empowerment of the judiciary in terms of legislative overrides, political tinkering with the appointment procedures of judges, court-packing attempts, and even the removal or impeachment of the judges such as sacking of superior courts in Thailand, Ecuador, and Pakistan. 
According to some scholars (Friedman, 1998; Ginsburg, 2004, Vallinder, 1995), the spread of judicial review in the world may be considered the judicialization of politics. Many other scholars (Arantes, 2005; Hirshl, 2004; Stone \& Brunnell, 2013) think that the courts are using their constitutional powers to exert against the other branches of the government, in particular parliaments. The status of written constitutions in controlling parliamentary actions is also expanding in many countries. There are some scholars (Cross and Lindquist, 2007; Magalhães, Guarnieri and Kaminis, 2006; Magalhães, 2003; Moustafa, 2007; Pederzoli and Guarnieri, 2008) who argue that judges play an active role in countering the excesses of the majoritarian institutions. They use the term judicial activism interchangeably with the judicialization of politics.

Another school of thought considers that when the judiciary acts freely and independently from the other branches of the government, commonly known as judicial independence, that this is equal to the judicialization of politics (Dressel, 2012; Ferejohn, Rosenbluth, and Shipan 2009; Scribner, 2010; Sieder, Schjolden and Angell, 2005). Similarly, Hirshl (2004, 2008) believes that the involvement of the judiciary in the core political controversies of a nation is a form of the judicialization of politics. Another line of scholars (Rios-Figueroa, 2007; Rios-Figueroa, and Taylor, 2006; Vianna, Burgos and Salles, 2007) argue that judicialization of politics occurs when the courts handle a lot of cases. On the other hand, some scholars (Figueroa, 2006; Hamlin, 2014) have found that the business of the courts in deciding cases might be due to other reasons, such as political bickering and competition among different political groups bringing their disputes to the courts in litigation. Some scholars in the field (Hamlin, 2014; Kagan, 2001; Kawar, 2014; Keleman, 2011; Tate and Vallinder, 1995) refer to the active role of some 
administrative or non-judicial institutions/organizations bringing different kinds of cases into the courts for the common good.

Some political scientists and scholars (Couso, Huneeus and Sieder, 2013; Rueda, 2013) see the social and behavioral change in the society regarding the reformation of new laws and statutes, i.e., the people in legal profession and non-judicial judicial organizations have become well aware and active in motivating and mobilizing the society about the laws and statues concerning their rights and issues. There are also some studies (Hirschl, 2004; Landfried, 1989; Stone, 1992; Vanberg, 1998; Sala, 2014; Volcansek,1992) that focus on the change in the behavior of legislatures due to the fact that the courts could use their power to review or nullify legislative action. In essence, legislative bodies anticipate judicial review by the courts and they change the laws and statutes accordingly to avoid judicial scrutiny. Ghias (2009) develops an argument that the failure of economic liberalization and public's discontent due to media attention could trigger the empowerment of the judiciary, as happened in Pakistan. The second point he makes is that the cooperation between bar and bench could also give the impetus for courts to assert their power and influence. According to him, the Public Interest Litigation (PIL) at the time of economic liberalization provided the Pakistan courts an opportunity to side with the public against the government resulting in the suspension of the superior judiciary by the Musharraf regime.

So, what was the impact of the LM on the judicial system of Pakistan? What follows examines both de jure and de facto aspects of changes after the LM, on both judges and the courts. Apart from the constitutional and legal changes, the Lawyers' Movement has brought some fundamental structural and functional changes in both legal practices and procedures as well as in professional institutions. 


\section{Major changes in Judicial Policy}

Chief Justice Chaudhary convened a meeting of the National Judicial Policy Making Committee (NJPMC) as its chairman on April, 18, 2009. The NJPMC was constituted under a Presidential Ordinance in 2002. The CJ of the Federal Shariat Court, the Chief Justices of all High Courts, and the Secretary Law \& Justice Commission are its members. In the light of the developments after the Lawyers' Movement, the NJPMC framed the first National Judicial Policy. The NJPMC proposed radical reforms to the judicial system of Pakistan. In Section A The Independence of Judiciary, the document for the first time set rules and procedures for judges to separate themselves from executive and administrative duties or assignments such as the holding of a position of an Acting Governor of a province and duties in general elections. The National Judicial Policy aimed to bring major reforms in both criminal and civil litigation in Pakistan, in particular, to eliminate unnecessary delay in handling cases.

Apart from the oath of office under the Constitution of 1973, judges of the Supreme Court and the High Court (Superior Courts) perform their duties under a Code of Conduct framed by the Supreme Judicial Council under the old Article 128 (4) of the Constitution of 1962 as amended later under Article 209 (8) of the Constitution of 1973 of the Islamic Republic of Pakistan. After the Lawyers' Movement, the Supreme Judicial Council in its meeting held on August 8, 2009 gave approval to the addition of a new article XI in the previous Code of Conduct for the judges of the Superior Courts and ordered the government to publish the full text of the amended code in the Gazette of Pakistan (Extraordinary) for the information of concerned people. There are eleven Articles of this Code including the added Article XI which states:

No Judge of the superior judiciary shall render support in any manner whatsoever, including taking or administering oath in violation of the oath, of office prescribed in the Third Schedule to the Constitution, to any authority that acquires power otherwise than 
through the modes envisaged by the Constitution of Pakistan. (Article-XI of Code of Conduct, p.2)

The addition of the Article XI in the Code showed the firm belief of the judges of the superior judiciary that they wanted to stop even the remote possibility of taking oath on another Provisional Constitutional Order (PCO) by another military adventurist in the future. For first time in the judicial history of Pakistan judges made themselves bound to their oath of allegiance to the Constitution only.

A respondent, SL 1, who participated in my study, explained the impact of this Movement on both superior and inferior courts in Pakistan. According to him the impact on the justices of the superior Courts is significant as compared to the lower judiciary at the Tehsil or District levels. He further elaborated:

I think it has made the judges more confident certainly more confident, much more confident, much more strident. The judiciary, it's a new judiciary, it's a new era in the history of Pakistan and I've great confidence that it will, in due course contribute a lot to that. A lot needs to be done about the subordinate judiciary but you can't change that in a day.

Another of my respondents, SL 2, felt that:

The LM has not changed the structures of the judiciary yet but it has tremendously increased the level of expectations of the people with the courts. It has raised tremendous expectations for them, some extremely unrealistic expectations and probably some have expectations of political nature.

A similar opinion was shared by a leading journalist, who agreed that the LM has not only raised the expectations of people, but improved the accountability of judges as well. Another journalist, and host of a primetime TV talk show, said that the judiciary had become bolder issuing judgments against the federal government in a number of cases. The respondent cited the overwhelming support of both the electronic and print media for the courts as a major factor empowering independence. 
A respondent, HCT Judge 4 mentioned only one positive impact of the LM on the political system of the country. He said:

At least one thing may be positive, at least the people who were in uniform and the government realized that now no judge can be thrown away just through a stroke of the pen. At the same time, the judiciary itself is sacking the judges without following the procedure.

A respondent, PS Professor 2, elaborated on the impacts of judiciary this way:

I think that judiciary knows very well, and they have acknowledged it many times, that without the sacrifices of the lawyers' community, they could not have achieved the status of independence that they have now. This means judges feel themselves morally bound to do something good for the society and particularly on the issue of democracy and military interventions. The CJ of the Supreme Court has been very clear in saying that democracy is what serves the interest of the country.

A former High Court justice, and one of the leaders of the LM, insisted that this

movement has had an impact on the judiciary, in particular, the judges have shown a new

commitment to uphold law and justice by accepting their mistakes from the past and vowing that they will not repeat those mistakes in future. A senior journalist respondent suggested the judiciary had a bright future because the LM had created public awareness among the masses regarding the rule of law and the role of the judiciary: "The public have developed an interest in knowing what is happening around them and why."

Similar views, that the role of judiciary is contingent on the role of other segments in society, were shared by Senator 1:

We are passing through a very transitory period. The judiciary is feeling very confident of itself because it has a public support; it has the support of the movement behind it, the movement support will still continue in the favor of the judiciary. That impact is still there and media is also supporting the judiciary so, therefore, the judiciary is feeling much stronger than the rest of the branches of the state.

Perhaps foremost among the political changes was the establishment of a separate Human Rights Cell to deal with cases of human rights violations. Justice Chaudhary appointed his close friend, then an ad hoc justice at the Supreme Court, Justice Khalil Ramday, as the head of this 
cell. The major function of the cell was to expeditiously process the human rights complaints from the general public (Kennedy, 2012). The Human Rights Cell was able to provide relief to the aggrieved parties without further delay and without going through the traditional litigation procedures and processes. In a period of one year and three months, the Supreme Court decided 53,082 cases of human rights violations and public policy out of a total 54,935 appeals (Shabbir, 2013, pp. 11-12).

In addition to the institutional changes that occurred, there were a series of significant court decisions that both differed from previous decisions and signaled a new level of judicial independence. In Federation of Pakistan v. Muhammad Nawaz Sharif (2009) PLD 61 SC 644, the Court revisited its earlier decision regarding the disqualification of Nawaz Sharif from public office and removed his disqualification, allowing Sharif run again in elections. This decision of the Court also created an electoral balance between PPP and PML-N in the upcoming general elections, allowing both political Benazir Bhutto and Mian Nawaz Sharif to participate (Kausar, 2011, p.35). In a second case, Muhammad Nawaz Sharif v. State, (2009) 61 PLD (SC) 814, 84748, the Supreme Court removed the conviction of Nawaz Sharif in the "hijacking case" case of 2000. The Court ruled that Nawaz Sharif was justified under civil aviation laws to prevent General Musharraf from returning to Pakistan to avoid a military coup d'état (Kalhan, 2013, p. $62)$.

On July 31, 2009, a larger bench comprising fourteen judges of the Supreme Court issued a landmark judgment in Sindh High Court Bar Association v. Federation of Pakistan 2009. This order declared the Emergency Proclamation Order (PCO) of November 3 unconstitutional. The Court declared the PCO, the judges Oath Order, the First and Second Amendment Orders, and the establishment of a new High Court Islamabad unconstitutional, ultra vires of the Constitution 
of 1973. For the first time in the judicial and political history of Pakistan, the Supreme Court of Pakistan explicitly made it clear that the role of the Armed Forces is limited to professional duties and barred them from future interference in politics, as the Court makes clear in its verdict:

Military rule, direct or indirect, is to be shunned once and for all. Let it be clear that it was wrongly justified in the past and it ought not to be justified in [the] future on any ground, principle, doctrine or theory whatsoever...Unless such an approach is firmly entrenched into the body politic and the jurisprudence of this country, military takeovers previously in the name of martial law, and later in the garb of proclamation of emergency will continue to recur as heretofore, there will be nothing to stop (PLD 2009 SC 879, Para 56).

In addition to the preceding, the Supreme Court issued a number of decisions to provide relief to the general public under its Public Interest Litigation (PIL) jurisdiction, declared a presidential appointment illegal, ruled on MPs fraudulent resumes, and established their jurisdiction over government contracting in a variety of fields. Clearly the post LM court was expanding its turf and responsibilities. Perhaps the best example of this new turf, and independence, was the trial of General Musharraf for high treason, brought at the request of the Prime Minister, Nawaz Sharif (Dawn, Dec. 18, 2019). On December 2017, the Special High Court found General Pervez Musharraf, who was in exile in Dubai, guilty of high treason.

\section{Judicial Independence before and after the LM: Analysis of the Survey}

As discussed in chapter 2, I gave my respondents a survey to gauge their measure of judicial independence in Pakistan. The respondents were given choices from poor to the excellent to rank the indicators or determinants of the JI in Pakistan before and after the Lawyers' Movement. The results of this survey are presented in Table 6.1 and support the views expressed by the respondents in my interview data and the documentary data I have presented. 
Most indicators show an increase after the LM; one, qualification of judges, stayed the same. I use a Paired Samples T- Test to significant changes in some important indicators/determinants of JI in Pakistan after the LM including: 1) authority of judicial review; 9) pay/salaries of the judges; 11) financial autonomy; 12) relationship with executive; and 15) public opinion/support.

As far as the relationship of the judiciary with other branches and institutions of the State are concerned such as executive, legislature, and the military, the nature of relations deteriorated compared to the past before the Lawyers' Movement. These changes are understandable given the Court's newfound interest in challenging the other power centers in the Pakistani polity. In fact, one might argue that the negative changes on these indicators actually show increased judicial independence in the Pakistan case. In the end, the results of this survey clearly show that the respondents felt that there was a significant increase in judicial independence in Pakistan after the LM.

\section{Status of the Judicial Independence after the Movement: Opinions of the Respondents}

As Table 6.1 shows, most respondents agreed that there was more JI after the LM, and the qualitative interview data support this conclusion. According to the respondents, judges feel more independence and freedom to render the decisions without fear or favor. The role of the judge as an individual and the judiciary as an institution has been improved tremendously. Some of my informants gave credit to CJ Chaudhary in that he was a linchpin of the whole judiciary and acted freely and independently. However, the majority of respondents speak of the improvement of the judiciary as a whole and the LM's role in that improvement.

For example, a respondent CSR 2 emphasized the importance of the LM in these words:

Of course, a huge change, a huge change and I'm not saying that I agree or disagree with what they are saying but the environment has changed. The judges who were like very 
subservient, very meek, now the environment is such that they have been given that kind of feeling of being elevated to that level that sense of responsibility also.

Table 6.1. Indicators/Determinants of Judicial Independence in Pakistan Since 1947

(Paired Samples T Test)

\begin{tabular}{|l|c|c|c|c|}
\hline Indicators & Before LM & After LM & & \\
& Mean & Mean & t & Sig. \\
\hline 1. Authority of judicial review & 2.10 & 3.14 & -4.396 & $.000^{*}$ \\
2. Appointment of judges & 2.03 & 2.60 & -2.036 & .051 \\
3. Qualification of judges & 2.50 & 2.50 & -.000 & 1.000 \\
4. Retention methods of judges & 2.29 & 2.39 & -.532 & .599 \\
5. Removal methods of judges & 2.28 & 2.31 & -.133 & .896 \\
6. Jurisdiction of the courts & 2.45 & 2.90 & -1.822 & .079 \\
7. Number of judges & 2.10 & 2.21 & -.516 & .610 \\
8. Administrative powers of judges & 2.63 & 2.83 & -1.000 & .326 \\
9. Pay/salaries of the judges & 2.43 & 3.37 & -5.635 & $.000^{*}$ \\
10. Term of office & 2.83 & 2.87 & -.239 & .813 \\
11. Financial autonomy & 2.45 & 2.93 & -4.525 & $.000^{*}$ \\
12. Relationship with executive & 2.76 & 1.97 & 3.237 & $.003 *$ \\
13. Relationship with legislature & 2.31 & 2.14 & .708 & .485 \\
14. Relationship with the military & 2.69 & 2.35 & 1.516 & .142 \\
15. Public opinion/support & 1.67 & 3.30 & -6.885 & $.000^{*}$ \\
\hline
\end{tabular}

CSR 2 further added:

I think a lot of things are happening and it's going to take shape. As I said things don't happen overnight but there are lot of things happening. First, now it is the Supreme Court that sets the tone for the whole judiciary, you know, that has changed. So that is, again people say that it's not big, it is something big, and it's a huge deal. So, don't underestimate that it's not something huge that has been changed and the appointments of the judges in the high courts, it has had changed and there is a trickledown effect and they are working on a lot of things. In the session courts they are working on numerous judicial reforms from a perspective that is now informed by the LM reforms. 
A respondent, HCT Judge 5, said the following about the changes to the judiciary after

the LM:

Rather than distinguish between significant or insignificant I feel the change after the LM is such that corruption cases are now attracting the attention of the judiciary. Similarly, mega-constitutional deviations are being taken notice of by the federal government and given suo motto jurisdiction. Similarly, the entire judiciary is falling into accordance with the rule of law, although it will take at least four to five years for this to be the norm. You cannot achieve miracles with Allah Din's Lamp.

Respondent LP 2 argued the appointment of judges had been improved post-LM:

We achieved a very transparent system of appointment of judges, there is a Judicial Commission, very appropriately represented by the judiciary and by the Executive and by the President. Its recommendations go to the parliamentary committee, which itself has very adequate proportional representation of the government and the opposition. So, the appointment process has become more transparent and accountable and judges are more secure at the moment with reference to appointment and removal. The Supreme Judicial Council rules have been framed which are fairer and transparent which ensure impartiality so the judges are not in fear of removal. Financially they are given more autonomy and now they are not as dependent as they were before the Lawyers' Movement. So, judicial independence status is very positive and sustained.

Another respondent, SL 2, added his views that the courts are more resilient to external

pressures:

The change is certainly visible, the change is visible as far as the High Courts and Supreme Court is concerned. The judges are more conscious. They are under pressure. The real test of this judiciary will come if as in the past there is any unconstitutional move to remove an elected government or to remove an elected parliament. I believe that it has become impossible for the present judiciary to stamp its name to any unconstitutional act and probably, I believe that is one reason why, despite a lot of hue and cry, it is not happened because I don't think this judiciary will ever be able to do that. So, yes, it's a huge step forward and it's because of this Movement. So, in that sense, I believe it's a big, big change.

A respondent, Senator 2, argued that the courts' new strength actually improves their

interactions with Parliament:

Yes, yes. Most certainly, I see that change and I know that there is a lot of skepticism and there is a talk of perhaps the judiciary overstepping but I'm not bother by this. I'm not bother by this ... for two reasons. A, if you look at it from a historical point of view then in any transitional developing democracy tug of wars within institutions, within the framework of the law and the constitution do take place. The thing to be watched and judged is whether institutions behave maturely or not and I think in terms of the $18^{\text {th }}$ 
amendment, in terms of the $19^{\text {th }}$ amendment, the judiciary acted very responsibly. And I think that parliament reciprocated very responsibly. So, to that extent I'm not perturbed. Questions of interpretations, a question of what is gray and what is black is always there and will always be there.

And another respondent, Senator 2 admitted:

After the Lawyers' Movement, judiciary has been independent, I would say yes, they are independent and what seems to have been done either by the CJ himself and together with his colleagues is to see that is rank and file is solid. So, first thing he has done is to see to it that all those judges, PCO judges, had taken oath after emergency and after they had issued the junction that they should not take oath. Whether they were good, whether they were very intelligent should not be among their rank and file.

A small group of respondents had the view that the judiciary has become more politicized or incompetent. And some of them argued that the judiciary got some independence, but only partially. One of my respondents, SL 5 presented a very bleak picture of the judiciary and the lawyers:

If the goal was to get rid of Musharraf, yes, they achieved that but in the process the judiciary is destroyed. The Islamabad High Court went down for years, 1,400 cases went unheard. One hundred and six judges were removed and we have still even today not able to fill that task. We have no judges, people don't want to become a judge. Lawyers for the first time learned violence. Now every day, we here of a lawyer thrashing a judge, whether it is in Faisalabad or elsewhere. I always thought that the practice of law related to logic, reason and prestige. Where is the rule of law? So, I think the lower judiciary is disheartened and destroyed.

\section{Financial Autonomy of the Courts}

The financial autonomy of the judiciary is highly linked with the independence of judiciary. The judiciary can perform its functions efficiently, effectively, independently, and fairly when it enjoys significant control over its financial support. It is the responsibility of the other branches of the government, such as legislature and executive branch, to ensure sufficient financial resources for the judiciary to perform its role properly and smoothly. A statement of principles adopted by the National Conference of Court Administrators and Conference of Chief Justices in the United States in 1965 asserted the need for financial independence for courts: 
Judicial finance, should be exercised free of interference by agents of the executive branch of the government, in the same manner that the executive and the legislative branches administer the funds appropriated for their internal operations (Ferguson, 1973, p. 975).

Similarly, the Supreme Court of Pakistan in Government of Sindh v. Sharaf Faridi PLD

1994 SC 105 has ruled that the allocation of funds for the judiciary is at the disposal of the judiciary itself without any interference from any agency of the executive. The Supreme Court in this judgment asserted that:

The Court held that the independence of judiciary also means the elimination of financial control of the Executive over the judiciary, and therefore, the CJ of the Supreme Court and High Courts should be authorized to make re-appropriation of funds within the budgetary allocation, without the approval of Finance Ministry. The Court went on to elaborate that the Chief Justices would thus be competent to re-appropriate amounts from one head to another and may also create or abolish posts and upgrade or downgrade the same. (Hussain, 2007, p.8)

\section{Public Support for the Judiciary}

Chief Justice William Rehnquist of the US Supreme Court rightly observed and suggested that "Justice is too important a matter to be left to the judges, or even to the lawyers; the American people must think about, discuss, and contribute to the future planning of their courts (Harahan \& Malik, 2000, p.1).” The image or perception of the courts among the general public is also a hallmark of the developed democracies of the world. Courts enjoy support and trust of the people, which enables them to perform their functions freely and independently. In this study, I ask my respondents to evaluate the impact of the LM on the public perception of the judiciary. Regardless of political background, I got near-unanimous positive response from my respondents that the LM has had a positive impact on the public view the courts.

A respondent, HCT Judge 5, discussed the impact of the LM on enhancing the image of the Courts among the people in these words: 
So, the impoverished class did not support the judiciary and vice-versa because neither had knowledge of the other. The Lawyers' Movement changed all this. Pakistan is now on the march to progress because the leadership is gradually, slowly becoming aware of the plight of the poor and in [the coming] years they will become vociferous .... I'm very clear that Lawyers Movement has ignited a flame that was only a flicker. It will strengthen Pakistan and Pakistan will have an excellent future.

A respondent LP 1 explained the LM's impact on general public opinion in these words:

Yes, the judiciary enjoys public support. The public wanted the supremacy of the constitution, an independent judiciary, the rule of law, democracy, and an accountable government. They were dependent on politicians to fight against the establishment to protect their rights, yet nobody responded to them for sixty years. So, they ultimately came to the conclusion that it is the judiciary which could assure all these things.

Still, not all agree with that assessment. A former high bar official disagreed with the notion that LM enhanced the image of the Courts among the general public, rather "it has misled and confused the public." He went on to argue that the people have started questioning the wisdom behind suo moto powers of the Superior Courts. Similarly, a High Court justice who participated in the LM, stated that "certainly it has raised tremendous expectations from them, some extremely unrealistic expectations and probably some have expectations of a political nature, so, it has enhanced the image but enhancing the image at the same time has tremendously enhanced the public's expectations."

\section{Changes in the Appointment and Removal Method of the Judges}

The process of the appointment of justices at the Superior Courts is a major determinant of their independence. Before the LM, the appointment of the judges at the High Court and Supreme Court levels was made by the concerned chief executives, the prime minster for the Federal level appointments, and the chief ministers of the Provinces at the High Court level (Ijaz, 2014, p. 87). However, the chief executives had to "consult" the respective chief justices for the appointments of judges, but the word 'consultation' was not defined by any law or a court decision. Normally, there existed an informal deal or understanding between the CJ and the chief 
executive about who should be on the bench. The common practice was that the CJ would send the names of the judges to be appointed and the chief executive would recommend to the Head of the State, the President for an appointment of a justice to the Supreme Court and the Governor in case of appointment to a High Court. The consultation among these three individuals was a kind of an informal agreement and the executives could reject the nominations made by the chief justices (Ijaz, 2014, pp. 87-88).

The major development after the LM was the adoption of the $18^{\text {th }}$ Amendment to the Constitution regarding the appointment of judges to the Superior Courts with the "consent" of a Judicial Commission where the judges were in majority. A Parliamentary Committee was established to approve the recommendations of the Judicial Commission. However, the Parliamentary Committee had no right to reject the recommendations made by the Judicial Commission without the valid written reasons (Ijaz, 2014, p. 88).

The respondents I interviewed had different perspectives about the $18^{\text {th }}$ Amendment and its impact on the JI in Pakistan. A respondent, LP 2, discussed the appointment process of judges after the $18^{\text {th }}$ Amendment in the Constitution and he said that after the change:

The appointment process has been changed fundamentally. Article 175-A has been incorporated which prescribes that there would be a judicial commission and there would be a parliamentary committee. All the recommendations by the judicial commission would be rectified by the parliamentary committee within fourteen days, if they are not rectified, they will be automatically presumed to be passed by the parliamentary committee and they would be sent to the Prime Minster and through the Prime Minister to the President, this is the procedure.

A respondent, SL 2 lauded these changes:

I think this present parliament has done a wonderful change and I think historic change that they brought about to the $18^{\text {th }}$ Amendment as far as the appointment of judges is concerned but it is just an initial period. What they have done is that at least involve the main stakeholders in the process of the appointment of judges has made it more transparent and more accountable on the paper at least. But it would require some fine tuning and it would require a change of mindsets which is a process that is already 
started. So, I believe that with time it will develop into system where it will function and I think it's already functional, far better than what was being practiced from last 65 years. A respondent, Senator 2, added:

When we sat down in the Parliamentary Committee at that time you would recall that controversy of a clash between Parliament and the Judiciary in particular on the appointment of judges was taking place. So, the Committee was very careful that it did not want to impinge on the independence of judiciary. Yet it wanted to introduce a transparent system in which individual discretion would be limited or would be done away with because the old system essentially was based on the discretion of the Chief Justices. Therefore, Article 175-A came out in the shape that it did and you see that it has majority of the judges in the Judicial Commission and you have the executive representatives.

In replying to the question of what was the utility or significance of the parliamentary

committee when the Supreme Court set aside its role in one case and ordered it to appoint those four judges who were rejected by the Parliamentary Committee, he said:

I think the real importance is the breakthrough. I think the real importance is the introduction of a new element and its acceptability. Yes, what we had envisaged the $18^{\text {th }}$ Amendment that to an extent has been curtailed by the $19^{\text {th }}$ Amendment and the subsequent decision of the Supreme Court but I am still optimistic. I am not one of those who say that the Parliamentary Committee is now been rendered, abducted, no I don't think so.

A respondent, Senator 1 discussed these issues:

Judges have been appointing judges and for some time it worked well and we found no complaint. I was also Minister for Law and Parliamentary Affairs in the Government of Pakistan for four years from 65 to 69. Judges then appointed and judges earlier appointed they all were very famous judges they became famous in their own juristic approach and there was no problem. In that case always there has been consultation by the judges with the administration of past. But the choice was mostly by the judges but later, during the time of politicians, it's unfortunate more during the times of politicians, there have been interference and they have been trying to get certain people appointed of their choice.

As far as the removal procedure of the judges is concerned, the removal method and the security of the tenure of service of the superior court judges have paramount importance with regard to the independence of judiciary. Under the Article 209 of the 1973 Constitution, the justices of the Superior Courts could be removed only by the Supreme Judicial Council.

However, after the restoration of the suspended CJ and some other judges, through the decision 
regarding the appointment of PCO judges in the Sindh High Court Bar Association Case, the

Supreme Court deposed more than 100 hundred judges of both the Supreme Court and High

Courts.

A respondent, HCT Judge 5, explained in detail the removal method and the concept of impeachment of judges:

I must say that all the judicial appointments and judicial removals they should put on TV, I don't want that judiciary should become arbitrator as it. CJ of Pakistan should become a totally dictatorial power, total absolute power. I say that we should try to examine this process of impeachment in a manner that the people should know that it is being conducted. A good man when invested with absolute power and functional condition to exercise that power in darkness, he becomes a Satan. So similar principle should be followed that transparency should not be written in the constitution, transparency should not be written in the TV, but transparency should be through such a method that people must try a lot to know.

\section{Accountability of the Judiciary}

Accountability of judges has paramount importance in terms of the independence of the judiciary as an institution and the independence of a judge as an individual. Judicial accountability should not be taken as opposite to the JI, but rather it enhances the independence of the judiciary. Accountability helps to maintain legitimate theoretical limits on the actions of the judiciary. To a larger extent it strengthens the independence of the judiciary. It also ensures that no one in the state is above the law and contributes to the principle of the rule of law. On this issue, I asked my respondents and they had different opinions in terms of how judges could be held accountable without usurping the legitimate powers of judges and courts.

Khan (2012) explains the concept of judicial accountability as follows:

The concept of JI is deeply connected with the accountability of judiciary. In India, the parliament can impeach the judges of the superior courts. The American political system's judges, who are highly independent because they are appointed for lifetime, can also be impeached by Congress. No institution can be built and progress without accountability. Pakistan is probably the only nation in the world where judges appoint judges and judges remove judges. Hence, one could say there is no system of independent 
accountability. According to the Constitution, under Article 209, there is a Supreme Judicial Council headed by the CJ of Pakistan and joined by other judges, which can remove a judge from his office. Only a handful of judges have been removed for misconduct through this process since the formation of Pakistan (Khan, 2012).

A respondent SJ 3 expressed his views on the subject and said that “...the journalist should criticize the $\mathrm{CJ}$ and the highest Courts if they exceed from their statuary powers in order to keep them under pressure and it's a good change which is growing slowly and steadily." Another respondent, HCT Judge 4 gave his opinion about the accountability, especially the system of judges judging the behavior of other judges: "I think there must be check on the judiciary and also through Parliament, through an institution rather I think the powers under article 209 should not remain with the judiciary that should go to a committee like Senate, etc. and through, at least the judges must have in their fear that if they do wrong that way they will be there to face the music." According to him, the powers of removal of superior court judges is in the hands of judges by themselves as under article 209 of the Constitution, the Supreme Judicial Council composed of senior judges of the Supreme Court and the High Courts is responsible for removing judges. For him, it is not fair that judges are accountable only to other judges and Parliament should have the power to make judges accountable.

One of my respondents, HCT Judge 1, endorsed the process of the accountability of judges under the Article 209 of the Constitution 1973 and focused on the self-accountability of judges. He gave the example of three judges, Justice Akhlaq Hussain, Justice Shoukat Ali, and Justice Fazal Ghani who were removed by the Supreme Council composed of judges. According to him, no other institution can make the judges accountable other than judges themselves, otherwise, it could diminish the independence of judiciary. 
A respondent, SCT Judge 1, expressed the view that the accountability of the justices has been made more open under the provision of the Article 209 in that any citizen of Pakistan could file a case of removal. He said:

It's there, the provision is there, and the question is if a judge misconducts himself, the provision is there. Simply now it's that provision that has been enlarged, previously it was the president of Pakistan who would file a complaint, who would invoke that provision. Now a complaint can come from any source and proceedings under 209 can be started. Somebody has to bell the cat that is somebody has to start the proceedings and the courts will take them on.

According to him, the accountability of the superior court judges is clear and open. Any citizen can file a removal reference to remove a judge from his or her position. Another respondent, SCT Judge 1, defended the accountability process of judges provided in the Constitution. He also defended the removal of the senior judges of the High Courts and Supreme Court through the Sindh High Court Bar Association Case:

There is accountability, which has also some provisions on Supreme Judicial Council which, there are provisions in the Constitution under article 209 that the judges, that anything against the judges can be considered in the supreme judicial council and if some misconduct was proved then he will be removed. But the removal authority that is the president, that is the executive. The process of holding the trial with regard to misconduct that is by the judges, i.e., the Supreme Judicial Council constituted under the Constitution.

\section{Relationship of the Judiciary with the other Branches of the Government}

The Courts do not work in a vacuum. Their smooth working is highly dependent upon their interactions with the other branches of the government and some other state institutions. In transitioning democracies like Pakistan, the work and performance of the Courts is not only dependent upon the textual or constitutional boundaries, but also on the informal relations with the other stakeholders in the state, including the military, which as an institution has played a key role in the performance of the superior courts in the past (Kausar, 2011, p. 37). 
There has been constant confrontation between the judiciary and civilian governments after the Lawyers' Movement. The Pakistan Peoples Party's (PPP) government came into power after the February 2008 general elections. Syed Yousaf Raza Gillani was elected as the Prime Minister of Pakistan by the National Assembly. After President Pervez Musharraf stepped down as the President, the PPP's Co-Chairperson Asif Ali Zardari was chosen as the elected President of Pakistan by the Parliament and the four Provincial Assemblies in the Electoral College for the election of the President. The PPP's Government restored almost all of the deposed judges of the Supreme Court and High Courts except the CJ and four other judges.

The delay in the reinstatement of $\mathrm{CJ}$ became a bone of contention between the restored judiciary and the PPP's Government. Later, under the leadership of CJ Chaudhary, the Supreme Court issued decision after decision that targeted the powers of the executive branch. The Supreme Court through its suo moto actions and using powers under 183 (4) of the Constitution of 1973, and the Contempt of Court Powers under the Article 204 of the Constitution, almost crippled the civilian Government. At one stage, the Court disqualified the Prime Minister of Pakistan on Contempt of Court charges and issued arrest warrants for sitting Prime Minister Raja Pervez Ashraf in a corruption case. Similarly, in the Memo-gate case, the Supreme Court exerted its pressure on tPresident Asif Ali Zardari to face charges of corruption and money laundering in a Swiss court (Waseem, 2012, pp. 16-18).

The second civilian regime after the LM of Mian Nawaz Sharif as Prime Minister after the May 2013 general elections also faced a similar defiant attitude from the Supreme Court. These tensions did not diminish, even after the retirement of Iftikhar Mohammad Chaudhary as CJ and judge of the Supreme Court. For the second time in history, the Supreme Court of Pakistan disqualified the Prime Minister of Pakistan as a member the National Assembly and as 
its leader disqualifying him from politics for life under the Article 62 (1) (f) of the Constitution of Pakistan. Previously, prime ministers were removed from their positions by presidents through powers granted under the Eighth Amendment. For the first time in the political history of the country, the judiciary removed and disqualified a prime minister using powers under the disqualification clause of Article 62 91) (f) of the Constitution of 1973. The same pattern continued in the third civilian regime of the PTI's Government of Imran Khan as Prime Minister. On December 15, 2017, the Supreme Court disqualified the senior most politician and close friend of the Prime Minister, and Secretary General of the ruling party, Pakistan Tehreek-e-Insaf (PTI), Jahangir Khan Tareen under Article 62 (1) (f) of the Constitution of 1973 and the Section 99 of the Representation of Peoples Act which states the qualifications of a member of the Parliament. One of the respondents, SL 3 agreed that the LM has changed the nature of the relationship between the judiciary and the other stakeholders:

Certainly, it has changed in a big way. In the sense that executive always appeared to be very powerful before the courts prior to 2007 meaning thereby the government was always the blue-eyed baby, the will of the law as well as the Courts. This was the perception among the people and they were afraid of going to the courts against the government because it thought that, ultimately, they will lose. But this is for the first time everybody is feeling that this Supreme Court or even the High Court does not care much about the Executive. It [judiciary] can give its verdict even on more sensitive issues like the High Court recently has said that the President cannot hold two offices, he cannot be head of the political party while being the President of the country so you have to quit as the Chairman of the party. So, this verdict has come from the High Court. So, what we are seeing that increasingly the High Courts and the Supreme Court are becoming assertive towards their own Legislature. The judges who were dropped by the Parliamentary Committee, their case was taken up by the Supreme Court and Parliamentary Committees' own decision to drop those judges has been set aside. And they have been asked to reappoint those judges and extend their tenure. So, judiciary is certainly asserting itself in a big way which was not there previously.

A respondent, PS Professor 1, endorsed the argument that there is a significant change in the relationship of the judiciary and the other stakeholders in Pakistani politics such as the executive, legislature, and the opposition parties. He stated “...well, I mean, the relationship is 
changed, judiciary is very active and lawyers are overconfident. Therefore, the relationship is changed. I think judiciary is more independent of parliament, it's more independent of the executive and it continues to reprimand these two institutions."

Another respondent, Politician 1, admitted that in the past there was no active role of the judiciary as an institution, however, after the LM, the judiciary has emerged as an active and powerful branch of the government. Thus, the other two players, the executive and the legislature are not happy with the changing role of the judiciary and there is tussle among these institutions and he believes it will continue well into the future.

A respondent examined the relations of the judiciary with the other stakeholders. CSR 2 said, “...of course it has changed because the other branches are feeling threatened because they are still part of their status quo and they are beneficiaries of a system that the judiciary is taking on. So, of course they are uncomfortable with an independent judiciary, very uncomfortable."

\section{Impact of the Movement on Pakistani Society at large}

Kareem (2010) focuses on the development of an effective and vibrant civil society in Pakistan after the LM. According to him, Pakistani society is passing through a transition from an authoritarian regime to a democratic system. He highlights the role of lawyers and their councils and bar associations in aiding this transition to democratic rule. He emphasizes the positive impact of the LM on the mindset of citizens and their ability to effect a change in the society through democratic means. The author also conducted 52 interviews of some high-level officials, civil society activists, and the leaders of the LM.

According to Kareem, the LM has had four major impacts on Pakistani society at large. First, the success of this movement is itself a major impact. It gave the general masses a feeling of empowerment and the confidence to bring change through a peaceful struggle. Second, it 
changed the mindset of the people in general about the concepts of democracy and the rule of law. It gave the impetus to other organizations and groups in the society that they could also achieve their goals through peaceful protests and movements. It brought a significant change in the processes and procedures of the protests of various groups in society such as the Pakistan Medical Association, and missing persons advocacy groups, etc. These groups better organized their protests to put pressure on governmental authorities. Third, unlike the past when the military took advantage of public protest and movements and directly intervened in the political system by staging a military coup d'état, during the Lawyers' Movement, the military did not engage. The unity among the judges and the lawyers played a key role this time in the transition and consolidating democratic norms in the society. Fourth, another major success of this movement was the inclusion of new social classes in the political arena such as educated, urban, civic, middle and lower classes became more aware of the fact that social and political change is possible through peaceful political struggle (Kareem, 2009, pp. 86-88).

Anwar (2009) considers the LM a social movement started by a professional group over a single issue. According to him, the transformation of a legal discourse into a social discourse and transitioning of a legal discourse into a social movement was a challenge for the research community. He also examines the role of modern communicative means, the private electronic mass media which gave the legal community an opportunity to communicate its message broadly. This research is based on focus group discussions (FGD) with the people from the legal profession in Pakistan. The results of these FGDs show that there was a consensus among the legal community that the main focus of the LM was the restoration of judges intertwined with the ultimate goal of JI and the rule of law in the country. 
A Harvard Law School Report (2010) also examines the immediate effects or impacts of the LM on Pakistani culture and society. The LM helped the general public to understand the role of the Constitution, the role of the courts, and the significance of the legal profession. It also created among the general masses a kind of collective identity with the lawyers, along with a pride that activist lawyers are an asset for the society as were national heroes and lawyers Gandhi, Jinnah, Nehru, and Iqbal. Similarly, the lawyers played a very crucial role in the struggles against Ayub Khan, Zulfikar Ali Bhutto, and Genera Zia-Ul-Haq in the past. According to this study, the LM had similar impacts on judges. Despite all the pressure from the Musharraf regime, judges also stood firm during the protests in the streets for the restoration of judiciary. A respondent, LP 2, strongly endorsed the idea that the LM has had a significant impact on Pakistani society as a whole:

The overall impact is still emerging, transitioning. We cannot conclude at the moment but the impact that has emerged up until now is that people are more conscious, people are thinking more democratically, they are not supporting the dictatorial governments and they are not supporting the Taliban style ideas. So, they have got more belief in these institutions and these principles. They are continuously working for that and this is expressed through civil society, the masses, the media interviews of the public, the print media in which they are writing the articles and through the demonstrations.

\section{Impact of the Movement on the Democratic Health of the Country}

Chapter 2 reviewed the literature on the role of courts in transitioning democracies like Pakistan. Courts can play one of two "upstream" roles when a polity is shifting from authoritarian rule to democracy: support for said change or choosing to stay out of the political process. After the Lawyers' Movement, the role of the courts in Pakistan has been mixed. The courts neither supported the military establishment nor the political democratic forces. The courts neither suppressed the democratic forces nor the remnants of the military regime.

Ultimately the Pakistani courts played it safe. In some cases, the courts handed down verdicts against the military establishment and favored the democratic forces or the opposition to the 
establishment. In other cases and situations, the courts suppressed the civil and democratic forces in order to placate the regime and to protect themselves. Due to this unique role of the Pakistan courts, the military has found no need to directly intervene in political affairs (Fruman, 2011, p. 17).

Historically, democracy in Pakistan has faced serious challenges in the past, in particular, the military intervened in politics four times through the dismissal of elected governments and the dissolution of elected assemblies (Fruman, 2011, pp. 5-6). And each time the military interventions were challenged in the courts which not only provided them with the legitimacy to rule, but in one case authorized the military dictator to amend the Constitution as he wished, an authority that the apex court itself did not possess.

In this study, I asked my respondents whether after the LM the superior judiciary is capable of being a bulwark against any military adventurism in future. The respondents have mixed opinions on the issue. Many of them have the view that the judiciary is more active and independent after the LM and could resist future moves by the military to topple constitutional governments. On the other hand, some of my respondents doubted the post-LM judiciary's ability to stop the military from intervening in political affairs.

Respondent, SJ 3, told me that the military would face stiff resistance from at least two institutions, the judiciary and the media, if it attempted a coup. According to him once the military was trying to use Nawaz Sharif against the government of Asif Ali Zardari and a few military officers came to him [SJ 3] and reminded him that once the media stood against Pervez Musharraf and forced him to step down and now the media should help the military to topple the Zardari regime. He stated that he told the military officers that when one ordinary citizen like him breaks the traffic signal, he is caught and punished, but when a military dictator breaks the 
Constitution then there is no punishment for him. Another respondent, SJ 1, had the view that if the military intervenes again it will be the last intervention because the country will split again. Historically, it is a fact that after the military regime of General Ayub Khan in 1970, the country was divided into two and Bangladesh became a separate state.

Conversely, a respondent, PS Professor 1, disagreed when asked if the modern judiciary could stop a military takeover:

Not necessarily, because you don't stop coups through judiciary because firstly under the present circumstance there is no chance of a coup in Pakistan in the near future due to a number of reasons, there are a lot of reasons. But let's assume for a minute, come on, Pakistan had four coups, there could be another one. Let's assume that happens and the military thinks that judiciary will be in the way, solution is very simple, they'll remove the judiciary.

Similar views were shared by a respondent, Senator 1 . According to him, the judiciary always sided with the military and most judges took oath under the PCOs and the judiciary will never be a bulwark against future military takeovers. Another respondent, SCT Judge 3 had the same opinion that the judiciary has historically validated military coups and would do so in future because it cannot stop the imposition of martial law on its own.

A respondent, Senator 2, also insisted that the judiciary cannot be a bulwark against any military coup, but it is the public who can stop a military dictator:

I feel that at most legislation and judicial judgments can be deterrence, they cannot be the bulwark against the military takeover. The only dam against the military takeovers are the people themselves. When a military dictator realizes that tomorrow if I takeover my writ is not going to be acceptable and I don't mean in the Supreme Court and the High Court, my writ out of the street is not going to be acceptable and there are going to be people outside. Then that is real deterrence.

Another respondent, SCT Judge 1, observed that in the future it will not be easy to curb the powers of the judiciary:

I believe the passage back to intervention has been blocked by exercise of its extraordinary jurisdiction by the Supreme Court in cases like Sindh High Court Bar Association, and I put time to see but I do not see the Supreme Court of Pakistan or High 
Court of Pakistan one way or the other going against the judgment or even trying to draw a distinction, it should be very difficult, very difficult.

\section{Achievements of the Lawyers' Movement}

Ahmed (2012) admits that the LM achieved its set objectives such as the removal of a dictator through the people power. A similar conclusion was drawn by the Asian Human Rights Commission (AHRC):

The contributions of the lawyers must be treated as a positive direction for the future political and democratic set up. The movement can be termed as a strong foundation stone of future democracy in Pakistan and it should be recognized by the new parliament (AHRC, 2008).

As far as the question of the success of this movement is concerned, the respondents in this study evaluated both success and failure differently. Many of my informants concluded that the LM had achieved its goals such as the restoration of the CJ and other judges, the independence of judiciary as an institution which is reflected in the various decisions rendered by the superior courts after the restoration, the appointment process where the judges were given more powers to appoint their colleagues, and most importantly the confidence of public in the courts was restored. Some of my respondents focused on the idea that for the first time in the judicial history of Pakistan, a new debate started to change or reform the structure of the whole judicial system in order to make it more effective and efficient. On this point respondent SL 2 stated:

It has started a process and I think that's a big achievement. It's a long way because it's not just one thing that needs to be reformed. Starting with the educational, the legal education you see. Starting the reforms from there and going right up to the top. I think everything needs and requires those reforms but at least this movement and the restoration has initiated debate and has consensus at least focused on various issues which at least would take a long time but that process has started and I believe that is the biggest achievement of this movement. 
A respondent, SCT Judge 2, said that “...I think so yes, judiciary is now independent at least I may say with regard to the superior judiciary." Another respondent, SCT Judge 1, concluded that:

I believe this Movement established a few principles. One that any action against the Constitution will not be upheld by the Courts, this result and this is there in the Constitution, it is there in the law books, this what the movement was for, and I believe today if any intervention under the present conditions are made, I don't think any court would undertake the adventure of validating any non-constitutional intervention, it will not. It's the result of this Movement.

One of the respondents, HCT Judge 1 added to this sentiment:

I think we have reinstituted the independent judiciary and judges and they are a check on corruption, and a check on discriminatory and arbitrary discretion and the people appreciate that very much. I think if there is one thing standing between corrupt administrators and their ability to fill in their coffers.

Respondent, SL 2 concluded that:

I will say there are two achievements which we have made on this front. One was of course the restoration of the CJ and judges who did not take oath on $3^{\text {rd }}$ of November that we achieved in March 2009. The other purpose was that we must cleanse the judiciary from those people who had cooperated with Musharraf or Musharraf's appointee CJ Dogar.

And HCT Judge 5 had more mixed opinions on the achievements of the LM:

This movement was partially successful, it was partially successful. What I mean is that for the first-time judiciary never acquiesced and judiciary stood up and resisted. When I say judiciary never acquiesced I say judiciary in 1954 acquiesced and surrendered before the might of gun and validated the act of usurpation by Munir. Then again in 1958 when Dosso case judgment was delivered. This judgment too was delivered under the bayonet.

\section{The Adverse Impacts of the Lawyers' Movement}

The most significant impact of the LM was on the judiciary itself. The Supreme Court of the post-Lawyers' Movement sent more than 110 judges of the Supreme Court and High Courts home due to their connection with the ousted regime. As far as adverse or negative impacts of the LM are concerned, one PCO High Court judge and a PCO Supreme Court justice, strongly 
disagreed that the LM was a successful social movement. Both were of the opinion that it divided the judiciary and brought incompetence to the institution. Respondent, SCT Judge 3 said:

Now you see they are disappointed. They are disappointed with their goal, they, some of them who started that movement with the object that independent judiciary would be there, the problems of people will be solved, and cases will be decided expeditiously. People have not to go to the Supreme Court at every petty matter but they are disappointed. Even those persons, who led the processions, who were on the forefront of that Lawyers' Movement, they are now disappointed.

After the Movement there were incidents in lower civil and district courts where lawyers misbehaved with the judges, including female judges. In some cases, the judges were beaten and injured by lawyers. In Multan, in a Lahore High Court bench, after a heated debate between the president of the Multan Bar Association and a High Court Judge, lawyers boycotted the court and blocked the doors of the courthouse, thus preventing judges from entering. The CJ of the Lahore Court, who is also an administrative head of the all courts in the Province intervened and facilitated a deal between the Bar Association and the judges.

A new term has been coined by the media regarding the rowdy behaviour of some lawyers, 'wukala gardi' (lawyers' hooliganism). Immediately after the LM in 2009, there was a rapid decline in the moral and social standing of the lawyers. Their image as heroes has been transformed into hooligans due to the violent actions of some lawyers, in particular, young lawyers, against other lawyers, police, litigants, judges, and other community groups like young doctors. There was a widespread perception among the public that the success of the LM against both military and civilian regimes and this newly-discovered power of defiance have emboldened the lawyers to undermine other segments of the society including their own, the legal fraternity (Leiby, 2012). 


\section{Conclusion}

In this chapter, I have analyzed the major impacts of the LM on the judicial system of Pakistan. The LM has brought significant changes in the structure and functioning of the courts. The LM emboldened the courts to challenge military and civilian political regimes and to hand down decisions to ensure the rule of law in the country. The courts made legislators, members of executive branch, including cabinet ministers and prime ministers, the civil and military bureaucracies, influential individuals, business icons, and their own colleagues accountable to the laws of the country. The judicialization of politics, or empowerment of the judiciary, is a major result of the LM, making the judiciary more independent and autonomous. This chapter suggests there has been a significant improvement in judicial independence since the LM.

The first major impact of the LM was constitutional. The addition of the Eighteenth and Nineteenth Amendments in the Constitution of 1973 introduced far-reaching reforms in the judicial system of Pakistan including the process of the appointments of the judges of the superior courts, their compensation, and the length of their tenure. There was also a fundamental change in Article Six of the Constitution of 1973 regarding capital punishment for the people who would subvert, abrogate or suspend the Constitution of 1973. For the first time in the nation's history, there is binding clause in the Constitution, Article 6 (2A) that calls for the same punishment for the judges of the superior courts if they validate an act of high treason. A separate cell for human rights litigation was established in the Supreme Court. The new Judicial Policy of 2009 overhauled the entire judicial machinery in the country and strengthened the independence of the judiciary and the rule of law. A new Code of Conduct was adopted for the judges of the superior courts that made them bound not to take oath "...to any authority that acquires power otherwise than through the modes envisaged by the Constitution of Pakistan." 
The majority of the respondents I interviewed in this study felt that the current judiciary have realized their independence as a result of the sacrifices of the LM and they want to preserve and protect it. Most of the respondents concluded that the judiciary after the LM enjoys strong support among the public. Some of my respondents also considered an independent judiciary a bulwark against any military adventurism in the country and they believed that the independence of judiciary and rule of law will strengthen the democratic values in the country; others disagreed.

Unlike its past history where the judiciary played a subservient role to the military establishment and validated their illegitimate rule applying the Doctrine of Necessity, or state necessity, the judiciary after the LM have played a remarkable role and challenged both military and civil regimes. While the impact of the LM on the judicial system of the country has been largely positive, like any large social movement it brought some unexpected negative results as well. It gave the general public a ray of hope, encouragement, and awareness regarding their fundamental, social, political, and constitutional or legal rights. On the other hand, there was some deterioration in the attitudes of some within the legal community, in particular, among younger lawyers. There were incidents of violence, hooliganism perpetrated by the lawyers against the police, judges, litigants, doctors, and their own colleagues. Still, overall, the LM was a peaceful, non-violent social movement for the restoration of the independence of judiciary and the rule of law in the country. While it lasted just two years, it mobilized all segments of the society and has led to lasting change. 


\section{Chapter 7}

\section{Conclusion}

\section{Introduction}

In this final chapter I briefly revisit my research questions, with a focus on the role of the courts in the process of transitioning to democracy, and the independence of the judiciary as an important pillar of democracy. I have analyzed the major impacts of the LM on the judicial system of Pakistan. The LM has brought significant changes in the structure and functioning of the courts. The LM emboldened the courts to challenge military and civilian political regimes and to hand down decisions to ensure the rule of law in the country. This chapter also examines the impacts of the LM on Pakistani society and the democratic health of the country. This chapter highlights the impact on the LM on de jure independence of the courts. The chapter concludes with some suggestions for further research.

\section{The Role of the Courts in a Transitioning Democracy}

As discussed in the literature review, courts play different roles in different types of regimes, and the role played by the courts is dependent on constitutional (textual), situational, and strategic variables. In addition, the role of courts in a transitioning democracy is highly contingent upon its relationship with the other branches of the government, in particular, the executive. The literature on the courts' role in transitioning democracies also divides the role of the courts into different phases, depending on the timing of regime change. As in the first phase, the upstream roles of the courts start either at the time when an authoritarian regime is near collapse, or in the early period of a new democratic government. Similarly, the downstream roles of the courts have two scenarios - either the courts strengthen the authoritarian positions or they 
consolidate the move to democratic forms of government. In some cases, the courts play no significant role.

In this regard, I asked my respondents how they saw the role of courts in a transitioning democracy like Pakistan. Senator 1 defined the roles of a judiciary to 'promote the parliamentary values' and 'values of democracy.'

Similarly, SL 1 stated:

I think in a democratic state like in our region, if you look at it from my point of view, the judiciary's role is little larger than it may be in a more historically-democratic state, where democratic traditions are much stronger, like USA, although again it is well known that in USA, the judiciary has been one of the main pillars of democracy. They are the ones who keep the Constitution a living organ of the state and have been able to enforce democratic traditions over there. Of course, there are periods when their record is not very amiable. But coming to cases like Pakistan, India, Bangladesh, and South Asia as a whole, we face real difficulties in democracy, especially in Pakistan where we had so many interventions - non-democratic and unconstitutional interventions, extraconstitutional interventions. So, the judiciary is called upon to play an even larger role than we know in the Western democracies.

He went on to describe the role of the judiciary in transitioning democracies as follows:

It has a very important role. It keeps everybody on track. It should be an activist role. I think I believe to consolidate democracy, whether it is in the early days of United States of America with a Chief Justice like John Marshall, or in the 60s and 70s in India, or in the 2000s in Pakistan. But to consolidate democracy, the judiciary must have a proactive role.

One of my participants, HCT Judge 5, described the role of the judiciary as dependent on both the larger political context and the individuals who filled the role of judge. According to him, in Pakistan's history, the judges in the superior judiciary were not free and independent. $\mathrm{He}$ also made the distinction between de jure and de facto independence.

On this topic, respondent LP 2 argued:

The judiciary in a democratic state is basically a creation of the law or a creation of the constitution. So, the role of the judiciary is to act in accordance with the constitution and law, and get out of any influence by the public, parliament or the government. There are two opinions. One school of thought thinks that democracy does nurture the independence of the judiciary, while the other says that it is the judiciary itself, or its independence nurtures democracy. You can say that in the present situation, an 
independent judiciary will ensure democratic values in this country, Pakistan. It will strengthen political and democratic institutions.

A respondent, SJ 1, stated that judiciary's role in a capitalist democracy is to protect the 'status quo' and to develop the perception among the common people that they are getting 'justice.' The judiciary always protects the rights of the dominant factions in the society and gives the common people a little 'piece of pie' to ensure that they will not stand against the state or will not go for the revolution or anarchy.

Conversely, respondent SL 4 stated:

Judiciary has to have a liberal mind, has to protect the rights of the common people, and has to empower the very downtrodden and the voiceless. The tones that they keep do not necessarily have to be used in the first place for empowering themselves, which is what has happened in Pakistan because public interest litigation, by and large was used by the judiciary to empower itself, to give it the powers to appoint judges. Now in my view, that is a very subservient way of using a very unique, and in a way, affective judicial emancipation if you would like to say it which into the fold of emancipation. Respondent LP 1 argued:

Judiciary is a corrective institution. It cannot build the distributive paradigm on its own. Distributive paradigm is to be laid out by the legislature and the people within that domain functioning in the distributive paradigm. Whatever goes wrong, the judiciary functions as a plumber, as an institution to fix those errors - a corrective institution. Since, we have thrown bigger challenges to judiciary, bigger than anything, almost compelling them to encroach on distribution.

PS professor 3 added:

One of the basic features, which should be there for the protection of the democracy in a state, is a judiciary, which should, of course, be independent. And because judiciary's role is to also protect the rights of the people, rule of law is already ensured over there. And for that very viable, very, you may say independent judiciary is required for any state, I think, to survive and to flourish.

Another respondent, PS professor 2, stated:

So, I think that judiciary has to be independent and autonomous. It should function as a custodian of the constitution and a final arbiter of constitutional disputes. So, we can't think of a democratic state without two things - separation of power and judicial independence. 
Finally, Senator 2 was of the view:

I think that first of all, judiciary, when we are talking in general terms, is a very important pillar of democracy. Not only is it there to interpret the constitution and the various laws, but it is also there to lend transparency in governance. In general terms, it is there to ensure that the rule of law is enforced and that every person is equal before law.

There is a consensus among the respondents that the role of the judiciary in a transitioning democracy, like Pakistan, is to act as an important pillar of democracy. It should safeguard the rights of the people through its interpretation of the Constitution and law. The courts should serve as the final arbiter in conflicts between the government and the people, to ensure equality and the rule of law. As chapter 3 illustrated, this role was too often unfilled before the Lawyers Movement. That said, as demonstrated in chapter 6, most of my respondents and those who study Pakistan agree that the courts are now serving this important role.

\section{Judicial Independence}

There is a consensus among the scholars and researchers in judicial politics that the role of the court is not automatic. Rather, it is heavily contingent upon certain traits or factors such as respect for the rule of law and the definition of judicial independence itself. JI is commonly viewed as an important feature of modern liberal democracies. There is a consensus among scholars that JI contains three significant features: impartial judges, respect for their decisions, and non-interference in their affairs.

There is a difference of opinion among the scholars over the measurement of JI (Hayo \& Voigt 2007; Ramseyer \& Rasmusen 2003; Rios-Figueroa, 2006; and Rosenn, 1987), however there is agreement that formal legal and constitutional safeguards like the appointment of judges, clear rules governing their retention and removal, their tenure, qualifications, and financial autonomy are key (Davis, 2002; and Ramseyer \& Rasmusen, 2003). Moreover, in a vibrant civil society, lawyers and their associations (Sarat \& Scheingold, 2001; and Chavez, 2008), and the 
public support in general, are also considered crucial aspects for the judicial independence and rule of law (Verner, 1984; and Vanberg, 2008).

Most of the respondents from the legal profession emphasized constitutional and textual guarantees for judges and courts when describing the concept. They mentioned a number of salient features such as: 1) transparent and fair appointment of the judges; 2) security of their tenure; 3) no interference from other branches of the governments in the affairs of the judiciary; 4) non-interference from the government or any other forces of the society in the decision making process of the courts; 5) the jurisdiction of the court and the role of the judges should clearly be defined; 6) the other branches of government, the executive in particular, should implement the decisions of the courts; and 7) the courts should have a control over their administration and should have financial autonomy.

For example, a respondent, SL1 argued:

JI implies that, first of all, the judges should be appointed through a process that is transparent and a process that is by law. The decisions taken at the highest possible level and the appointments therefore, should not be tainted (as far as possible) with favoritism, nepotism or with any corrupt motives. The first is the appointment process. The second is the security of the tenure. The judge once appointed should have the security of tenure; he should know that he cannot be removed except through a process that, again, is fair and solemn and matches the dignity, the high dignity of the office of the judge. And third is that judges themselves should avoid becoming politically partisan or getting into political debates and issues. So, the independence of judges is important but it is a structural issue, more than an emotional or a personal issue.

Some of the respondents focused on the importance of education or qualification of the judges. They were of the opinion that the education in law should be of a fine quality or high standard. Judges should be skilled, deserving, and experienced, having the ability to work independently without fear and favor.

As a respondent LP 3 stated: 
I feel that even before independence, there should be an independent quality people at place, first. Not just the formal qualification but integrity, their integrity, their human quality. First, we need this society and academia to produce that quality people, then we introduce them in the courts, and then we have independent judiciary that will be the idealist judiciary.

One of the respondents stated that the judiciary must have the ability to control their budget. Another suggested that judges should understand their limitations, staying within its constitutional limits when deciding cases. As a respondent, PS professor 2 emphasized on the significance of JI and the implementation of the court decisions:

By JI, what comes up to my mind is that judiciary is not a subordinate institution that would serve political interests of a particular political class and will stand as an institution, stand above the political foray and will be above the political polarization and conflict in the society, and by staying above and out of these conflicts, will provide justice to all - by resolving the constitutional, and other problems. It is both autonomy from the state, from the executive, and also autonomy from powerful social influences.

He further added:

There wouldn't be a JI if the decisions of the court are not implemented, it is clear. If there is no regard by the executive (which I believe that by a constitution, an executive is bound to implement the decisions of the courts), it means that it is violating the constitution as well as the autonomy and independence of the courts.

One of the respondents, Senator 2, highlighted the importance of the checks and balances among different institutions. He was of the view that JI could only be ensured when there is a constitutional mechanism to check the performance or working of an institution by another institution:

I think there is a worldwide concept of an independent judiciary and the concept of an independent judiciary, essentially, is also to be worked within the broad parameters of what the constitution of a particular country or state requires now. For example, in Pakistan after the 1973 constitution, it introduced a trichotomy of power between the judiciary, the executive and the legislature, and as long as the three organs continue to function within the trichotomy, it provides a very natural check and balance between the two. 
As suggested in chapters 5 and 6, these conditions for judicial independence are being fulfilled following the Lawyers Movement. That said, several of my respondents worried about the pressures to return to the status-quo prior to the Lawyers Movement. One, Senator 1, suggested that historically the civilian governments put more pressure on the courts than military rulers. Another, Senator 2, worried that the "coalescing of interests" of civil and military bureaucracies, the religious right, and the media could pressure the judiciary, making it dependent, ineffective and unworthy.

\section{The Impact on the De Jure Independence of Judiciary}

The first major impact of the LM was constitutional. The addition of the Eighteenth and Nineteenth Amendments in the Constitution of 1973 introduced far-reaching reforms in the judicial system of Pakistan including the process of the appointments of the judges of the superior courts, their compensation, and the length of their tenure.

There was also a fundamental change in Article Six of the Constitution of 1973 regarding capital punishment for the people who would subvert, abrogate or suspend the Constitution of 1973. For the first time in the nation's history, there is binding clause in the Constitution, Article $6(2 \mathrm{~A})$ that calls for the same punishment for the judges of the superior courts if they validate an act of high treason. A separate cell for human rights litigation was established in the Supreme Court. Former CJ Chaudhary formed the new Judicial Policy of 2009 in order to overhaul the entire judicial machinery in the country and strengthen the independence of the judiciary and the rule of law. A new Code of Conduct was adopted for the judges of the superior courts that made them bound not to take oath "...to any authority that acquires power otherwise than through the modes envisaged by the Constitution of Pakistan." 


\section{The Impact on the Democratic Health of the Country}

The majority of the respondents I interviewed in this study felt that the current judiciary have realized that their independence as a result of the sacrifices of the LM and they want to preserve and protect it. Most of the respondents concluded that the judiciary after the LM enjoys strong support among the public. Some of my respondents also considered an independent judiciary a bulwark against any military adventurism in the country and they believed that the independence of judiciary and rule of law will strengthen the democratic values in the country; others disagreed.

Unlike its past history where the judiciary played a subservient role to the military establishment and validated their illegitimate rule applying the Doctrine of Necessity, or state necessity, the judiciary after the LM have played a remarkable role and challenged both military and civil regimes. CJ Iftikhar Mohammad Chaudhary issued numerous judgments giving relief to the people and to protect the fundamental rights of the people took suo moto notices of the violation of the rules by the government agencies. In some cases, the Supreme Court made the government accountable before the rule of law and passed judgments against the excesses of the executive. In one contempt of court case, the Supreme Court disqualified the chief executive, the Prime Minister of Pakistan from his position. Another prime minister was disqualified for failing to declare his assets or income. In the Sindh High Court v. Federation of Pakistan case, the Supreme Court ruled more than one hundred judges of the superior courts ceased to be the judges by declaring their appointments illegal and unlawful.

While the impact of the LM on the judicial system of the country has been largely positive, like any large social movement it brought some unexpected negative results as well. It gave the general public a ray of hope, encouragement, and awareness regarding their fundamental, social, political, and constitutional or legal rights. On the other hand, there was 
some deterioration in the attitudes of some within the legal community, in particular, among younger lawyers. There were incidents of violence, hooliganism perpetrated by the lawyers against the police, judges, litigants, doctors, and their own colleagues, the lawyers. This was very unfortunate and a sad impact of the LM in the country. Still, overall the LM was a very peaceful, non-violent social movement for the restoration of the independence of judiciary and the rule of law in the country. While it lasted just two years it mobilized all segments of the society for the noble causes of an independent judiciary and a healthy democracy in Pakistan. The Lawyers' Movement challenged both civil and military regimes and ensured the safety of the fundamental rights of the people. The LM brought the Pakistani courts the will and strength to exert its own power to protect the rights of the people of Pakistan.

\section{Suggestions for Future Research}

I hope that this dissertation has increased our understanding of the impact of the Lawyers Movement in Pakistan. The LM demonstrated how peaceful protest could bring change in a democratic direction. It should serve as an example to political, religious, and sectarian groups on how to best achieve their goals. Some of these movements have applied the same techniques and processes in recent protests, for example, young doctors and other paramedical staff. Thus, there are different ways to further analyze the effects of the LM on Pakistani institutions such as the legislature, the executive, the bureaucracy, the military establishment, and the lower courts. Other areas of further research could examine special cases relating to public interest law, human rights, constitutional interpretation, women's rights, and labor law. Social and political movements have economic, political, and socio-psychological implications for both individuals and groups. Future research might be fruitful in exploring how the Lawyers Movement impacted social society and individual beliefs. 


\section{References}

Aberbach, J. D., \& Rockman, B. A. (2006). The past and future of political administrative relations: Research from bureaucrats and politicians to in the web of politics-and beyond. International Journal of Public Administration, 29, 977-995.

Adeney, K., \& Wyatt, A. (2004). Democracy in South Asia: Getting beyond the structure-agency dichotomy. Political Studies, 52, 1-18.

Ahmed, D. M. (2007). Legitimacy crises in Pakistan: A comparative study of political behavior. Journal of Political Studies, 12, 7-13.

Ahmed, P. (2013). Changing role and image of judiciary in Pakistan from 1988-1999 [Unpublished PhD thesis]. Bahaudin Zakria University, Multan.

Ahmed, S. S. (2012). The judiciary of Pakistan and its role in political crises. Karachi: Royal Book Company.

Ahmed, Z. S. (2012). The role of the Pakistani mass media in the lawyers' resistance against the Musharraf dictatorship, 2007-2009. Pakistaniaat: A Journal of Pakistan Studies, 4(3), 6177.

Ahmed, Z. S., \& Stephan, M. J. (2010). Fighting for the rule of law: Civil resistance and the Lawyers' Movement in Pakistan. Democratization, 17(3), 492-513.

AHRC. (2008). Pakistan: Lawyers' Movement is the 'vanguard of democracy'. Asian Human Rights Commission (AHRC). Retrieved March 15, 2008 from http://www.humanrights.asia/news/ahrc-news/AHRC-STM-053-2008

Almond, G. A. (1963). Political systems and political change. American Behavioral Scientist, $6(10), 3-10$. 
Almond, G. A., \& Powell, G. B. Jr. (1966). Comparative politics: A developmental approach. Boston: Little Brown.

Almond, G. A., \& Powell, G. B. Jr. (1987). Comparative politics: System, process, and policy. Lahore: Ferozsons.

Amenta, E., \& Polletta, F. (2019). The cultural impacts of social movements. Annual Review of Sociology, 45, 279-299.

Amenta, E., \& Young M. P. (1999). Democratic states and social movements: Theoretical Arguments and Hypotheses, 46(2), 153-168.

Amenta, E., Caren, N., Chiarello, E., \& Su, Y. (2010). The political consequences of social movements. Annual Review of Sociology, 36, 287-307.

Amin, S. M. (2015). A concise history of Pakistan. Karachi: Oxford University Press.

Anwar, M. (2009). How does a single professional issue become social movement discourse?: Case of Lawyers' Movement in Pakistan [Unpublished Master's thesis]. Institute of Social Studies, Hague, Netherlands.

Arantes, R. B. (2005). Constitutionalism, the expansion of justice and the judicialization of politics in Brazil. In R. Sieder, L. Schjolden \& A. Angell (Eds.), The judicialization of politics in Latin America (pp. 231-262). New York: Palgrave Macmillan.

Arendt, H. (1951). The origins of totalitarianism. New York: Harcourt Brace.

Arthur, M. M. L. (2011). Student activism and curricular change in higher education. Burlington, VT: Ashgate.

Asia Report. (2008, October 16). Reforming the judiciary in Pakistan. Washington D. C.: International Crisis Group. 
Aslanidis, P. (2012). Occupy populism: Social movements of the Great Recession in comparative perspective [Unpublished doctoral dissertation]. University of Macedonia.

Avello, M. (2007). Transitional justice: A European perspective. Madrid: Fridge.

Awan, M. R. (2014). Judicial activism in Pakistan in commercial and constitutional matters: Let justice be done though the heavens fall. University of Bedfordshire.

Barnett, R. E. (2004). The original meaning of the judicial power. Georgetown Law Faculty Publications and Other Works 839. Retrieved from https://scholarship.law.georgetown.edu/facpub/839.

Bengali, Q. (2018). A cry for justice. Karachi: Oxford University Press.

Bloom, A. (2008). Practice style and successful legal mobilization. Law and Contemporary Problems, 71(2), 1-16.

Bolognani, M. (2010). Virtual protest with tangible effects: Some observation on the media strategies of 2007 Pakistan anti-emergency movement. Contemporary South Asia, 18(4), $401-412$.

Bonastia, C. (2012). Southern stalemate: Five years without public education in Prince Edward County, Virginia. Chicago: Chicago University Press.

Bratton, M., \& Walle, N. V. D. (1997). Democratic experiments in Africa: Regime transition in comparative perspective. Cambridge University Press.

Brohi, A. K. (1958). Fundamental laws of Pakistan. Karachi: Din Muhammadi Press.

Buechler, S. M. (1993). Beyond resource mobilization? Emerging trends in social movement theory. The Sociological Quarterly, 34(2), 217-235.

Buechler, S. M. (1995). New social movement theories. The Sociological Quarterly, 36(3), 441464. 
Carothers, T. (2002). The end of the transition paradigm. Journal of Democracy, 13 (1), 5-21.

Chavez, R. B. (2004). The rule of law in nascent democracies: Judicial political Argentina. Stanford: Stanford University Press.

Chavez, R. B. (2008). The rule of law and the courts in democratizing regimes. In K. E. Whittington, R. D. Kelemen, \& G. A. Caldeira (Eds.), The Oxford handbook of law and politics (pp. 63-80). Oxford University Press.

Choudhary, G. W. (1969). Constitutional development in Pakistan. London: Longman.

Clark, T. S. (2011). The limits of judicial independence. New York: Cambridge University Press.

Colin, C. (2010). The 18th amendment and Pakistan's political transitions. Retrieved from https://www.americanprogress.org/issues/security/news/2010/04/19/7587/the-18thamendment-and-pakistans-political-transitions/

Colon, E. E. (2003). The state of judicial independence in Latin America: A framework evaluating judicial independence and the success or failure of judicial reforms. (Ph.D. dissertation, Department of Political Science, University of Houston, USA).

Couso, J., Huneeus, A., \& Sieder, R. (Eds.). (2011). Cultures of legality: Judicialization and political activism in Latin America. New York: Cambridge University Press.

Creswell, J. W. (2009). Research design: Qualitative, quantitative, and mixed methods approaches. 3rd ed. Thousand Oaks, CA: Sage.

Cross, F. B. (2008). The theory and practice of statutory interpretation. Stanford University Press.

Dahl, R. A. (1971). Polyarchy: Participation and opposition. New Heaven: Yale University Press. 
Davis, J. (2002). Judicial independence and the protection of equality in state high courts [Unpublished Ph.D. Dissertation]. Georgia State University.

Dawood, J. M. (1994). The role of superior judiciary in the politics of Pakistan. Lahore: Royal Book Company.

Denzin, N. (Ed.). (1970). Sociological methods. Chicago: Aldine.

Dijk, F. V., \& Vos, G. (2018). A method for assessment of the independence and accountability of the judiciary. International Journal for Court Administration, 3. URL: http://www.iacajournal.org

Dodge, J., Ospina, S. M., \& Foldy, E. G. (2005). Integrating rigor and relevance in public administration scholarship: The contribution of narrative inquiry. Public Administration Review, 65(3), 286-300.

Dressel, B. (Ed.). (2012). The judicialization of politics in Asia. London: Routledge.

Earl, J. (2004). The cultural consequences of social movements. In D. A. Snow, S. A. Soule, \& H. Kriesi (Eds.), The Blackwell companion to social movements (pp. 508-30). Malden, MA: Blackwell.

Eisinger, P. K. (1973). The conditions of protest behavior in American cities. American political science review, 67(1), 11-28.

Epp, C. R. (1998). The rights revolution: Lawyers, activists, and supreme courts in comparative perspective. University of Chicago Press.

Epstein, S. (2016). The politics of health mobilization in the United States: The promise and pitfalls of “disease constituencies.” Social Science \& Medicine, 165, 246-54.

Eyerman, R., \& Jamison, A. (1991). Social movements: A cognitive approach. University Park: Pennsylvania State Press. 
Faqir, K., Islam, F., \& Rizvi, S. H. (2013). The lawyers' movement for judicial independence in Pakistan: A study of Musharraf regime. Asian Journal of Social Sciences \& Humanities, 2(2), 345-357.

Feld, L. P., \& Voigt, S. (2003). Economic growth and judicial independence: Cross-country evidence using a new set of indicators. European Journal of Political Economy, 19(3), 497-527.

Ferejohn, J. (1999). Independent judges, dependent judiciary: Explaining judicial independence. Southern California Law Review, 72, 353-384.

Ferejohn, J., Rosenbluth, F., \& Shipan, C. R. (2009). Comparative judicial politics. In C. Boix \& S. C. Stokes (Eds.), The Oxford handbook of comparative politics (pp. 727-751). Oxford University Press.

Ferguson, W. S. (1973). Judicial financial autonomy and inherent power, Cornell Law Review, $57(6), 975-990$.

Fetner, T. (2016). Rethinking institutional infrastructures: Institution building as social movement activity. Presentation at ASA Annual Meeting 2016. Sociology Publications.

Friedman, B. (1998). The history of the countermajoritarian difficulty, part one: The road to judicial supremacy. New York University Law Review, 73, 333-433.

Fruman, S. (2011). Will the long march to democracy in Pakistan finally succeed? Washington, D. C.: US Institute of Peace.

Galanter, M. S. (1983). Mega-law and mega-lawyering in the contemporary United States. In R. Digwall \& P. Lewis (Eds.), The sociology of the professionals: Lawyers, doctors, and others (pp. 152-176). London: Macmillan. 
Gall, C. (2009, March 17). Reinstatement of the Pakistan's chief justice ends the crisis, but it might lead to another. The New York Times.

Gauri, V., and Brinks, D. M., ed., (2008). Transforming legal theory in the light of practice: The judicial application of social and economic rights to private orderings. In Courting social justice: Judicial enforcement of social and economic rights in the developing world. Cambridge University Press.

Ghani, R. (2010, September 8). Independence of judiciary. Pakistan Observer.

Ghias, S. A. (2010). Miscarriage of chief justice: Judicial power and the legal complex in Pakistan under Musharraf. Law \& Social Inquiry, 35(4), 985-1022.

Ghias, S. A. (2012). Miscarriage of Chief Justice: lawyers, media, and the struggle for judicial independence in Pakistan. Fates of Political Liberalism in the British Post-Colony: The Politics of the Legal Complex, New York: Cambridge University Press, 340, 77.

Gibler, D. M., \& Randazzo, K. A. (2011). Testing the effects of independent judiciaries on the likelihood of democratic backsliding. American Journal of Political Science, 55(3), 696709.

Ginsburg, T. (2003). Judicial review in new democracies: Constitutional courts in Asian cases. Cambridge University Press.

Ginsburg, T. (2012). Courts and new democracies: Recent works. Law \& Social Inquiry, 37(3), $720-742$.

Ginsburg, T., \& Moustafa, T. (2008). Rule by law: The politics of courts in authoritarian regimes. Cambridge University Press.

Giugni, M., Mcadam, D., Tilly, C. (Eds.). (1999). How social movements matter. University of Minnesota Press. 
Giugni, M. G., \& Grasso, M. T. (2016). The biographical impact of participation in social movement activities: Beyond highly committed new left activism. In L. Bosi, M. G. Giugni, \& K. Uba (Eds.), The consequences of social movements (pp. 85-105). Cambridge: Cambridge University Press.

Gloppen S., Wilson B.M., Gargarella R., Skaar E., Kinander M. (2010) Accountability functions of courts: A framework for inquiry. In: Courts and power in Latin America and Africa. Palgrave Macmillan, New York.

Guo, S. (1999). Democratic transition: A critical over view. Issues and Studies, 35(4), 133-148.

Gurney, J. N., \& Tierney, K. J. (1982). Relative deprivation and social movements: A critical look at twenty years of theory and research. The Sociological Quarterly, 23(1), 33-47.

Gurr, T. R. (1970). Why men rebel. Princeton University Press.

Halfmann, D. (2011). Doctors and demonstrators: How political institutions shape abortion law in the United States, Britain, and Canada. Chicago: University of Chicago Press.

Halliday, T. M., \& Feeley. L. K. (Eds.). (2007). Fighting for political freedom: Comparative studies of the legal complex for political liberalization. Oxford: Hart Publishing.

Hamilton, A., Madison, J., \& Jay, J. (2005). The federalist papers. Hackett Publishing.

Hamlin, R. (2014). Let me be a refugee: Administrative justice and the politics of asylum in the United States, Canada, and Australia. New York: Oxford University Press.

Harahan, S., \& Malik, W. H. (2000). Partnerships for reform: Civil society and the administration of justice. Washington, D.C.: World Bank.

Harvard Law School Report. (2010). The Pakistani lawyers' movement and the currency of judicial power. Harvard Law Review, 123, 1705-1726. 
Hassan, T. (2009). The Supreme Court of Pakistan and the case of missing persons. Asia-Pacific Journal on Human Rights and the Law, 2, 23-42.

Hayo, B., \& Voigt, S. (2007). Explaining de facto judicial independence. International Review of Law and Economics, 27(3), 269-290.

Helmke, G. \& Rios-Figueroa, R. (Eds.). (2011). Courts in Latin America. Cambridge University Press.

Helmke, G. \& Staton, J. K. (2011). The puzzling judicial politics of Latin America: A theory of litigation, judicial decisions, and interbranch conflict. In G. Helmke \& R. Figueroa (Eds.), Courts in Latin America (pp. 306-331). Cambridge University Press.

Hilbink, L. (2007). Judges beyond politics in democracy and dictatorship: Lessons from Chile. Cambridge University Press.

Hilbink, T. M. (2004). You know the type...: Categories of cause-lawyering. Law and Social Inquiry, 29(3), 657-698.

Hirschl, R. (2004). Towards juristocracy: The origins and consequences of the new constitutionalism. Cambridge, MA: Harvard University Press.

Hirschl, R. (2008a). The judicialization of mega politics and the rise of political courts. Annual Review of Political Science, 11, 93-108.

Human Rights Watch. (2007). Destroying legality: Pakistan's crackdown on lawyers and judges. New York: Human Rights Watch.

Huntington, S. P. (1993). The third wave: Democratization in the late twentieth century. Norman: University of Oklahoma Press.

Hussain, F. (2015). The judicial system of Pakistan. Islamabad: Supreme Court of Pakistan. 
Hussain, W. (2018). The judicialization of politics in Pakistan: A comparative study of judicial restraint and its development in India, the US and Pakistan. Taylor \& Francis.

Huyse, L., (2009). The criminal justice system as a political actor in regime transitions: The case of Belgium, 1944-50. The politics of retribution in Europe: World War II and its aftermath, (Eds.), Istvan, D. J. T., Gross, Judt, T. Princeton University Press.

Ijaz, S. (2014). Judicial appointments in Pakistan: Coming full circle. LUMS Law Journal, 1(1), $86-95$.

Jaffrelot, C. (2015). The Pakistan paradox: Instability and resilience. Oxford University Press.

Jenkins, J. C. (1983). Resource mobilization theory and the study of social movements. Annual Review of Sociology, 9, 527-553.

Kagan, R. A. (2001). Adversarial legalism: The American way of law. Cambridge, MA: Harvard University Press.

Kaiser, A. (1997). Types of democracy: From classical to new institutionalism. Journal of Theoretical Politics, 9(4), 419-444.

Kalhan, A. (2013). "Gray zone" constitutionalism and the dilemma of judicial independence in Pakistan. Vanderbilt Journal of Transnational Law, 46, 1-49.

Kareem, A. (2010). Civil society in transition: Pakistan and the Lawyers' Movement [Unpublished B.A in Honors thesis]. Stanford University.

Karl, T. L. (1990). Dilemmas of democracy in Latin America. Comparative Politics, 23(1), 1-21.

Kausar, T. (2011). Judicialization of politics and governance in Pakistan: Constitutional and political challenges and the role of the Chaudhary Court. In A. Misra \& M. E. Clarke (Eds.), Pakistan's stability paradox: Domestic, regional, and international dimensions (pp. 28-45). London: Routledge. 
Kawar, L. (2014). Commanding legality: The juridification of immigration policy making in France. Journal of Law and Courts, 2(1), 93-116.

Kazimi, M. R. (2009). A concise history of Pakistan. Karachi: Oxford University Press.

Keilitz, I. (2018). Viewing judicial independence and accountability through the "Lens" of performance measurement and management. International Journal for Court Administration, 3. URL: http://www.iacajournal.org

Keleman, R. D. (2011). The political foundations of judicial independence in the European Union. Journal of European Public Policy, 19(1), 43-58.

Kennedy, C. H. (2012). The judicialization of politics in Pakistan. The Judicialization of Politics in Asia, 12. Retrieved from https://lawexplores.com/the-judicialization-of-politics-inpakistan/

Kerbo, H. R. (1982). Movements of "crisis" and movements of "affluence." Journal of Conflict Resolution, 26(4), 645-663.

Khan, A. (2007a). A lawyers' mutiny in Pakistan. Kansas: Washburn University School of Law. Khan, A. (2007b). The Lawyers' Movement in Pakistan. Retrieved from https://www.researchgate.net/publication/228190831.

Khan, A. (2008). Pakistan in 2007: More violent, more unstable. Asian Survey, 48(1), 144-153.

Khan, A. I. (2007). The judge, the media and the general. The World Today, 63(6), 24-25.

Khan, H. (2009). Constitutional and political history of Pakistan. Oxford University Press.

Khan, H. (2016). A history of the judiciary in Pakistan. Oxford University Press.

Khan, M. A. (1967). Friends not masters: A political autobiography. Oxford University Press.

Khan, S. A. (2012, December 11). Essence of democracy. The Express Tribune. Retrieved from https://tribune.com.pk/story/477770/essence-of-democracy 
Khan, S. A. (2012, December 25). Judicial independence. The Express Tribune. Retrieved from https://tribune.com.pk/story/483823/judicial-independence

Khan, S. A. (2012, November 5). Accountability: A hollow hope. The Express Tribune. Retrieved from https://tribune.com.pk/story/461072/accountability-a-hollow-hope Kilwein, J. C. (1997). Still trying: Cause lawyering for the poor and disadvantaged in Pittsburgh, Pennsylvania. In A. Sarat \& S. Scheingold (Eds.), Lawyering on the left: Causes, politics, and professional responsibility (pp. 181-200). New York: Oxford University Press.

King, B. G., \& Pearce, N. A. (2010). The contentiousness of markets: Politics, social movements, and institutional change in markets. Annual Review of Sociology, 36, 249-67.

Klug, H. (2000). Constituting democracy: Law, globalism and South Africa's political reconstruction. New York: Cambridge University Press.

Kokab, R. U. (2013). Lawyers' Movement in Pakistan. Lahore: Pakistan Study Center.

Kornhauser, W. (1959). Power and participation in the local community. Health Education Monographs, 6, 28-40.

Landfried, C. (1985). The impact of the German Constitutional Court on politics and policyoutputs. Government and Opposition, 20, 522-541.

Landfried, C. (1989). Legislation and judicial review in the Federal Republic of Germany. In C. Landfried (Ed.), Constitutional review and legislation: An international comparison (pp. 166-167). Baden-Baden: Nomos.

La Porta, R., Lopez-de-Silanes, F., Pop-Eleches, C., \& Shleifer, A. (2004). Judicial checks and balances. Journal of Political Economy, 112(2), 445-470.

Law and Justice Commission of Pakistan. (2009). National judicial policy 2009. Islamabad: Law and Justice Commission of Pakistan. 
Le Bon, G. (1895). The crowd: A study of the popular mind. New York: Macmillan.

Leiby, R. (2012, November 11). Once hailed as heroes, Pakistani lawyers now seen as 'gangsters.' The Washington Post.

Lichbach, M. I. (1998). Contending theories of contentious politics and the structure-action problem of social order. Annual Review of Political Science, 1, 401-424.

Lijphart, A. (1984). Democracies: Patterns of majoritarian and consensus government in twentyone countries. Yale University Press.

Linzer, D. A., \& Staton, J. K. (2015). A global measure of judicial independence, 1948-2012. The Journal of Law and Courts.

Lipset, S. M. (1959). Some social requisites of democracy: Economic development and political legitimacy. The American Political Science Review, 53(1), 69-105.

Lollini, A. (2010). Constitutionalism and transitional justice in South Africa. New York: Berghan Books.

Long, R. D. (Ed.). (2015). A history of Pakistan. Karachi: Oxford University Press.

Luban, D. (1988). Lawyers and justices. An ethical study. Princeton University Press.

Luker, K. (1984). Abortion and the politics of motherhood. Berkeley: University of California Press.

Magalhães, P. (2003). The limits to judicialization: Legislative politics and constitutional review in the Iberian democracies [Unpublished doctoral dissertation]. Ohio State University.

Magalhães, P. C., Guarnieri, C., \& Kaminis, Y. (2006). Democratic consolidation, judicial reform, and the judicialization of politics in southern Europe. In R. Gunther, P. N. Diamandouros \& D. A. Sotiropoulos (Eds.), Democracy and the state in the New Southern Europe (pp. 138-196). Oxford University Press. 
Mainwaring, S. (1989). Transitions to democracy and democratic consolidation: Theoretical and comparative issues. The Helen Kellogg Institute for International Studies. Working paper No. 133.

Malik, M. A. (2008). The Pakistan Lawyers' Movement: An unfinished agenda. Islamabad: Pakistan Law House.

Maluka, Z. K. (1995). The myth of constitutionalism in Pakistan. Karachi: Oxford University Press.

Mari, M. K. B. (1990). A judge may speak. Lahore: Ferozsons.

McAdam, D. (1982). Political process and the development of black insurgency, 1930-1970. Chicago: University of Chicago Press.

McAdam, D., McCarthy, J. D., \& Zald, M. N. (Eds.). (1996). Comparative perspectives on social movements: Political opportunities, mobilizing structures, and cultural framings. Cambridge University Press.

McAdam, D., Tarrow, S., \& Tilly, C. (2001). Dynamics of contention. Cambridge University Press.

McAdam, D., Tarrow, S., \& Tilly, C. (2008). Methods for measuring mechanisms of contention. Qualitative Sociology, 31, 307-331.

McCarthy, J. D., \& Zald, M. N., (1977). Resource mobilization and social movements: A partial theory. American Journal of Sociology, 82(6), 1212-1241.

Meierhenrich, J. (2008). The legacies of law. New York: Cambridge University Press.

Meyer, D. S. (2014). The politics of protest: Social movements in America. Oxford University Press. 
Mihai, M. (2010). Transitional justice and the quest for democracy: Towards a political theory of democratic transformations [Unpublished doctoral dissertation]. University of Toronto.

Millward, P., \& Takhar, S. (2019). Social movements, collective action and activism. New Social Movements, 53, NP1-NP12.

Mintz, J. A. (2008). Introductive note: A perspective on Pakistan's chief justice, judicial independence and rule of law. ILSA Journal of International and Comparative Law, 15(1), 1-6.

Moor, B. (1966). Social origins of dictatorship and democracy. Penguin University Books.

Morris, A. (2000). Reflections on social movement theory: Criticisms and proposals. Contemporary Sociology, 29(3), 445-454.

Moustafa, T. (2007). The struggle for constitutional power: Law, politics, and economic development in Egypt. Cambridge University Press.

Moustafa, T. G. T. (Ed.). (2008). Rule by law: The politics of courts in authoritarian regimes. New York: Cambridge University Press.

Munir, M. (2014). Precedent in Pakistani law. Karachi: Oxford University Press.

Musharraf, P. (2006). In the line of fire. New York: Free Press.

Neudorf, L. (2017). The dynamics of judicial independence: A comparative study of courts. Springer Nature.

Newberg, P. R. (1995). Judging the state, courts and constitutional politics in Pakistan. London: Cambridge University Press. 
North, D., \& Weingast, B. (1989). Constitutions and commitment: The evolution of institutions governing public choice in 17th century England. Journal of Economic History, 49(4), 803-832.

Oberschall, A. (1973). Social Conflict and Social movements. Prentice Hall.

O’Donnell, G. (1979). Tensions in the bureaucratic-authoritarian state and the question of democracy. In D. Collier, \& F. H. Cardoso (Eds.), New authoritarianism in Latin America (pp. 285-318). Princeton University Press.

O’Donnell, G., Schmitter, P., \& Whitehead, L. (1986). Transitions from authoritarian rule: Comparative perspectives. John Hopkins University Press.

O’Neil, P. H. (1996). Revolution from within: Institutional analysis, transitions from authoritarianism, and the case of Hungary. World Politics, 48(4), 579-603.

Olson, M. (1965). The logic of collective action. Harvard University Press. Organski, A. F. K. (1965). The stages of political development. New York: Knopf.

Ospina, S. M., \& Dodge, J. (2005). It's about time: Catching method up to meaning - the usefulness of narrative inquiry in public administration research. Public Administration Review, 65(2), 143-157.

Palma, G. D. (1991). After Leninism: Why democracy can work in Eastern Europe? Journal of Democracy, 2(1), 21-31.

Pederzoli, P., \& Guarnieri, C. (2008). The judicialization of politics: Italian style. Journal of Modern Italian Studies, 2(3), 321-336.

Polleta, F. (2002). Freedom is an endless meeting: Democracy in American social movements. Chicago: The University of Chicago Press. 
Polletta, F. (2008). Culture and movements. The Annals of the American Academy of Political and Social Science, 619, 78-96.

Polletta, F., \& Jasper, J. M. (2001). Collective identity and social movements. Annual Review of Sociology, 27, 283-305.

Prillaman, W. (2000). The judiciary and democratic decay in Latin America: Declining confidence in the rule of law. Praeger.

PRS Group. (2013). International country risk guide. http://www.prsgroup.com/icrg.aspx.

Ramseyer, J. M., \& Rasmusen, E. B. (2003). Measuring judicial independence: The political economy of judging in Japan. Chicago: University of Chicago Press.

A report on judicial independence and integrity in Pakistan. (2009). London: International Bar Association.

Rickford, R. (2016). Black lives matter. New Labor Forum, 25(1), 34-42.

Ríos-Figueroa, J. (2006). Judicial independence: Definition, measurement and its effects on corruption: An analysis of Latin America [Unpublished doctoral dissertation]. New York University.

Ríos-Figueroa, J. (2007). The emergence of an independent judiciary in Mexico 1994-2002. Latin American Politics and Society, 49(1), 31-57.

Ríos-Figueroa, J., \& Taylor, M. M. (2006). The institutional determinants of the judicialisation of policy in Brazil and Mexico. Journal of Latin American Studies, 38, 739-766.

Rochon, T. R. (1998). Culture moves: Ideas, activism, and changing values. Princeton, N.J.: Princeton University Press.

Rosenbluth, F. (2009). Regimes and the rule of law: Judicial Independence in Comparative Perspective. The Annual Review of Political Science, 12, 345-366. 
Rosenn, K. S. (1987). The protection of judicial independence in Latin America. The University of Miami Inter-American Law Review, 19(1), 1-35.

Roy, W. G. (2013). Reds, whites, and blues: Social movements, folk music, and race in the United States. Princeton, N.J.: Princeton University Press.

Rueda, P. (2013). Legal language and social change during Colombia's economic crisis. In J. A. Couso, A. Huneeus, \& R. Sieder (Eds.), Cultures of legality: Judicialization and political activism in Latin America (pp. 25-50). Cambridge University Press.

Russell, P. H., \& O’Brien, D. M. (2001). Judicial independence in the age of democracy: Critical perspectives from around the world. University of Virginia Press.

Sala, G. (2014). Can courts make federalism work? A game theory approach to court-induced compliance and defection in federal systems. Economies, 2(4), 193-217.

Samdani, K. M. A. (2002). Role of the judiciary in the constitutional crises of Pakistan. Lahore. Jehangir Books.

Samdani, K. M. A. (2004). Justice, jaiza. Lahore: Sang-e-e Meel.

Sarat, A., \& Scheingold, S. A. (2004). Something to believe in: Politics, professionalism, and cause lawyering. Stanford University Press.

Sarat, A., \& Scheingold, S. A. (Eds.). (1998). Cause lawyering: Political commitments and professional responsibilities. Oxford University Press.

Sarat, A., \& Scheingold, S. A. (Eds.). (2001). Cause lawyering and the state in a global era. Oxford University Press.

Sarat, A., \& Scheingold, S. A. (Eds.). (2005). The worlds: Cause lawyers make structure and agency in legal practice. Stanford University Press. 
Sarat, A., \& Scheingold, S. A. (Eds.). (2006). Cause lawyers and social movements. Stanford University Press.

Sarwar, M. (2003). Comparative Governments. Ilmi Kitab Khana, Lahore.

Schelling, T. (1960). The strategy of conflict. Harvard University Press.

Schmitter, P. C. (1992). The consolidation of democracy and representation of social groups. American Behavioral Scientist, 35(4/5), 422-449.

Schmitter, P. C., \& Karl, T. L. (1991). What democracy is ... and is not. Journal of Democracy, 2(3), 75-88.

Schumpeter, J. A. (1976). Capitalism, socialism and democracy. New York: Harper.

Scribner, D. L. (2004). Limiting presidential power: Supreme Court-Executive relations in Argentina and Chile [Unpublished doctoral dissertation]. University of California, San Diego.

Scribner, D. L. (2010). The judicialization of (separation of powers) politics: Lessons from Chile. Journal of Politics in Latin America, 2(3), 71-97.

Shabbir, S. S. (2013). Judicial activism shaping the future of Pakistan. SSRN Electronic Journal. Retrieved from https://papers.ssrn.com/sol3/papers.cfm?abstract_id=2209067

Shah, A. (2014). The army and democracy: Military politics in Pakistan. Harvard University Press.

Shah, N. H. (1986). Constitution, law and Pakistan affairs. Lahore: Wajidalis.

Shapiro, M. (1964). Law and politics on the Supreme Court. New York: Free Pres.

Shapiro, M. (1986). Courts: A comparative and political analysis. University of Chicago Press.

Sheikh, N. (2009). Democracy and rule of law in Pakistan: Challenges and opportunities. Berlin: Orient. 
Siddique, O. (2015). The judicialization of politics in Pakistan: The Supreme Court after the Lawyers’ Movement. In M. Tushnet \& M. Khosla (Eds.), Unstable constitutionalism: Law and politics in South Asia (pp. 159-191). New York: Cambridge University Press.

Sieder, R., Schjolden, L., \& Angell, A. (2016). The judicialization of politics in Latin America. New York: Palgrave.

Smelser, N. J. (1962). Theory of collective behavior. Louisiana: Quid Pro Books.

Smulovitz, C. (2011). Judicialization in Argentina: Legal culture or opportunities and support structures. In, Cultures of legality: Judicialization and political activism in Latin America. (Eds.). In Couso, J., Huneeus, A., \& Sieder, R. (Eds.). (2011). Cultures of legality: Judicialization and political activism in Latin America. New York: Cambridge University Press.

Snow, D. A., \& Oliver, P. E. (1995). Social movements and collective behavior: Social psychological dimensions and considerations. In K. S. Cook, G. A. Fine, \& J. S. House (Eds.), Sociological perspectives on social psychology (pp. 571-599). Boston: Allyn \& Bacon.

Snyder, J., \& Leslie, V. S. (2004). Trials and errors: Principles and pragmatism in strategies of international justice. International Security, 20, 5-22.

Staggenborg, S. (2015). Social movements. Oxford University Press.

Stephenson, M. C. (2003). When the devil turns: The political foundations of independent judicial review. The Journal of Legal Studies, 32(1), 59-89.

Stone, A. (1989). In the shadow of the constitutional council. The 'juridicisation' of the legislative process in France. West European Politics, 12(2), 12-34. 
Stone, A. (1992). The birth of judicial politics in France: The constitutional council in comparative perspective. New York: Oxford University Press.

Stone, S. A., \& Brunnell, T. L. (2013). Trustee courts and the evolution of international regimes: The politics of majoritarian activism in the European Convention on Human Rights, the European Union, and the World Trade Organization. Journal of Law and Courts, 1(1), $61-88$.

Stotzky, I. (2003). Lessons learned and the way forward. Democratization, 20, 5-44.

Supreme Court of Pakistan. (2009). Code of conduct for judges of the Supreme Court and the High Courts. Retrieved from http://www.supremecourt.gov.pk/web/page.asp?id=435

Talbot, I. (2009). Pakistan: A modern history. London: Hurst.

Tarrow, S. G. (1998). Power in movements: Social movements and contentious politics. Cambridge University Press.

Tate, C. N. (1987). Judicial institutions in cross-national perspectives: Towards integrating courts into the comparative study of politics. In J. R. Schmidhauser (Ed.), Comparative judicial systems: Challenging frontiers in conceptual and empirical analysis. Boston, MA. Butterworths.

Tate, C. N., \& Vallinder, T. (1995). The global expansion of judicial power: The judicialization of politics. In C. N. Tate \& T. Vallinder (Eds.), The global expansion of judicial power (pp. 1-10). New York University Press.

Taylor, V. A., \& Van Dyke, N. (2004). Get up, stand up: Tactical repertoires of social movements. In D. A. Snow, S. A. Soule, H. Kriesi, \& H. J. McCammon (Eds.), The Blackwell companion to social movements (pp. 482-498). Oxford: Blackwell. 
Tilly, C. (1976). Major forms of collective action in Western Europe 1500-1975. Theory and Society, 3(3), 365-375.

Tilly, C. (1978). From mobilization to revolution. Addison Wesley.

Tilly, C. (1984). Social movements and national politics. In C. Bright, \& S. Harding (Eds.), Statemaking and social movements: Essays in history and theory (pp. 297-317). Ann Arbor: University of Michigan Press.

Tinker, H. (1968). The foundations of local self government in India, Pakistan, and Burma. London: Pall Mall Press.

Traub, H. (2008, June 1). The lawyers' crusade. The New York Times.

Useem, B. (1998). Breakdown theories of collective action. Annual Reviews of Sociology, 24, 215-238.

Vallinder, T. (1994). The judicialization of politics. A world-wide phenomenon: Introduction. International Political Science Review, 15(2), 91-99.

Vanberg, G. (1998). Abstract judicial review, legislative bargaining, and policy compromise. Journal of Theoretical Politics, 10(3), 299-326.

Vanberg, G. (2005). The politics of constitutional review in Germany. Cambridge University Press.

Verner, J. G. (1984). The independence of supreme courts in Latin America: A review of the literature. Journal of Latin American Studies, 16(2), 463-506.

Voigt, S., \& Hayo, B. (2007). Explaining de facto judicial independence. International Review of Law and Economics, 27, 269-290.

Volcansek, M. L. (1992). Judicial politics and policy-making in Western Europe. Frank Cass. 
Wallis, R. (1979). Salvations and protest: Studies of social and religious movements. London: Francis Printer.

Waseem, M. (2012). Clash of institutions in Pakistan. Economic and Political Weekly, 47(28), 16-18.

Watch, H. R. (2007). Destroying legality: Pakistan's crackdown on lawyers and judges. Human Rights Watch, 19, 1-84.

Weingast, B. R. (1997). The political foundations of democracy and rule of law. American Journal of Political Science, 91, 245-263.

Whittier, N. (2004). The consequences of social movements for each other. In D. A. Snow, S. A. Soule, H. Kriesi, \& H. J. McCammon (Eds.), The Blackwell companion to social movements (pp. 331-552). Oxford: Blackwell.

William, A. (1990). The strategy of social protest. Belmont, CA: Wadsworth.

Wolf-Phillips, L. (1980). Constitutional legitimacy: A study of the doctrine of necessity. London: Third World Foundation.

Zafar, S. M. (2019). History of Pakistan: Reinterpreted. Lahore: Ahsan Raza Printers.

Zaidi, K. (2008). Promoting an independent judiciary as a rule of law principle: A brief commentary on the Supreme Court of Pakistan. Retrieved from https://works.bepress.com/cgi/viewcontent.cgi?article=1003\&context=kamaal_zaidi

Zald, M. N. (1996). Culture, ideology and strategic framing. In D. McAdam, J. D. McCarthy, \& M. N. Zald (Eds.), Comparative perspectives on social movements: Political opportunities, mobilizing structures, and cultural framings (pp. 261-275). Cambridge: Cambridge University Press. 
Zald, M. N., \& McCarthy, J. D. (1979). The dynamics of social movements: Resource mobilization, social control, and tactics. Cambridge, MA: Winthrop.

Ziring, L. (1997). Pakistan in the twentieth century: A political history. Oxford University Press. 


\section{Annexure A}

\section{West WirginiaUniversity \\ Eberly College of Arts and Sciences}

February 1, 2011

Letter of Introduction for Mr. Shabbir Khan

Dear Madam or Sir:

I sincerely hope this letter finds you well. I am writ

letter on behalf of $\mathrm{Mr}$. Shabbir Khan. dissertation chairman at the Departited States of America. West Virginia University in the United States of America. Mr. Khan's dissertation (Judicial independence in Pakistan: A Case Study of the Lawyers' Movement, 2007-2009) examin. To political impact of the Lawyers' Movement ln pakistarival data complete his dissertation, Mr. Khan must collect archivaliews of unavailable in the United States and with important information judges, lawyers and other individua

about the Pakistani justice system.

I am respectfully asking you to participate in $\mathrm{Mr}$. Khan's important research by allowing him to interview you on your 作 views on recent events that hav $\mathrm{Mr}$. Khan is required to provide system. I can assure you that mat your participation will not you with complete anonymity and that including his completed be mentioned

dissertation.

Thank you so much for considering my request, and if I can provide you with any additional information, please do not presitate to contact me at jkilweinewvu.edu or 304-293-3811 x 5287 .

Very Sincerely Yours,

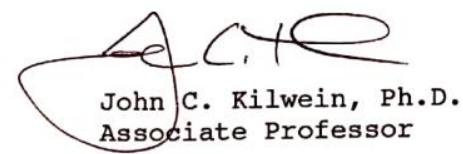

Department of Polltical Sclence 


\title{
Annexure B
}

\author{
CODE OF CONDUCT TO BE OBSERVED BY JUDGES OF THE SUPREME COURT OF PAKISTAN AND OF THE \\ HIGH COURTS OF PAKISTAN \\ (Supreme Judicial Council) \\ NOTIFICATION
}

Islamabad, the 2nd September, 2009

No.F.SECRETARY-01/2009/SJC.-In exercise of powers conferred by Article 209(8) of the Constitution of Islamic Republic of Pakistan, 1973, the Supreme Judicial Council in its meeting on 8th August, 2009 approved the addition of a new Article No. XI in the Code of Conduct for Judges of the supreme Court and High Courts and in its meeting on 29th August, 2009 decided to publish the full text of amended Code of Conduct in the Gazette of Pakistan (Extraordinary) for information of all concerned as under:-

Code of Conduct for Judges of the Supreme Court and High Courts (Framed by the Supreme Judicial Council under Article 128 (4) of the 1962 Constitution as amended upto date under Article 209 (8) of the Constitution of Islamic Republic of Pakistan 1973).

The prime duty of a Judge as an individual is to present before the public an image of justice of the nation. As a member of his court, that duty is brought within the disciplines appropriate to a corporate body.

The Constitution, by declaring that all authority exercisable by the people is a sacred trust from Almighty Allah, makes it plain that the justice of this nation is of Divine origin. It connotes full implementation of the high principles, which are woven into the Constitution, as well as the universal requirements of natural justice. The oath of a Judge implies complete submission to the Constitution, and under the Constitution to the law. Subject to these governing obligations, his function of interpretation and application of the Constitution and the Law is to be discharged for the maintenance of the Rule of Law over the whole range of human activities within the nation.

To be a living embodiment of these powers, functions, and obligations calls for possession of the highest qualities of intellect and character. Equally, it imposes patterns of behavior, which are the hall-mark of distinction of a Judge among his fellow-men.

In this code, an attempt is made to indicate certain traditional requirements of behavior in the Judges of the Superior Courts, conducive to the achievement of a standard of justice worthy of the nation.

\section{ARTICLE-}

On equiponderance stand the heavens and the earth. By equiponderance, oppression meaning unjust and unequal burdens is removed. The Judge's task is to ensure that such equality should prevail in all things.

\section{ARTICLE- II}

A Judge should be God-fearing, law-abiding, abstemious, truthful of tongue, wise in opinion, cautious and forbearing blameless, and untouched by greed. While dispensing justice, he should be strong without being rough, polite without being weak, awe inspires in his warnings and faithful to his word, always preserving calmness, balance and complete detachment, for the formation of correct conclusions in all matters coming before him.

In the matter of taking his seat and of rising from his seat, he shall be punctilious in point of time, mindful of the courtesies, careful to preserve the dignity of the Court, while maintaining an equal aspect towards all litigants as well as lawyers appearing before him.

\section{ARTICLE- III}

To be above reproach, and for this purpose to keep his conduct in all things, 'official and private, free from impropriety is expected of a Judge.

ARTICLE- IV

A Judge must decline resolutely to act in a case involving his own interest, including those of persons whom he regards and treats as near relatives or close friend. 
A Judge must rigidly refrain from entering into or continuing any business dealing, howsoever unimportant it may be, with any party to a case before him. Should the dealing be unavoidable, he must discontinue his connection with the case forthwith. A judge must refuse to deal with any case in which he has a connection with one party or its lawyer more than the other, or even with both parties and their lawyers.

To ensure that justice is not only done, but is also seen to be done, a Judge must avoid all possibility of his opinion or action in any case being swayed by any consideration of personal advantage, either direct or indirect.

\section{ARTICLE- $V$}

Functioning as he does in full view of the public, a Judge gets thereby all the publicity that is good for him. He should not seek more. In particular, he should not engage in any public controversy, least of all on a political question, notwithstanding that it involves a question of law.

\section{ARTICLE- VI}

A Judge should endeavor to avoid, as far as possible, being involved, either on his own behalf or on behalf of others, in litigation or in matters which are liable to lead to litigation such as industry, trade or speculative transactions.

To employ the influence of his position to gain undue advantage, whether immediate or future, is a grave fault.

A Judge must avoid incurring financial or other obligations to private institutions or persons such as may embarrass him in the performance of his functions.

\section{ARTICLE- VII}

Extra-Judicial duties or responsibilities, official or private, should be generally avoided. He should equally avoid being a candidate, for any elective office in any organization whatsoever.

\section{ARTICLE- VIII}

Gifts are to be received only from near relatives and close friends, and only such as are customary. Everything in the way of favours in consequence of the office must be refused. In accepting any entertainment offered, whether general or particular, care should be taken that its real purpose does not conflict with a Judge's duty to maintain detachment from likely litigants, and from partisan activity.

\section{ARTICLE- IX}

In his judicial work, and his relations with other Judges, a Judge should act always for the maintenance of harmony within his own Court, as well as among all Courts and for the integrity of the institution of justice. Disagreement with the opinion of any Judge, whether of equal or of inferior status, should invariably be expressed in terms of courtesy and restraint.

\section{ARTICLE- X}

In this judicial work a Judge shall take all steps to decide cases within the shortest time, controlling effectively efforts made to prevent early disposal of cases and make every endeavor to minimize suffering of litigants by deciding cases expeditiously through proper written judgments. A Judge who is unmindful or indifferent towards this aspect of his duty is not faithful to his work, which is a grave fault.

\section{ARTICLE- XI}

No Judge of the superior judiciary shall render support in any manner whatsoever, including taking or administering oath in violation of the oath, of office prescribed in the Third Schedule to the Constitution, to any authority that acquires power otherwise than through the modes envisaged by the Constitution of Pakistan.

\section{By order of the Council, \\ (Dr. Faqir Hussain) \\ Secretary}

